VINÍCIUS COOPER CAPETINI

\title{
Efeito da suplementação com zinco na evolução da resistência à insulina induzida por dieta hiperlipídica em camundongos
}

Dissertação apresentada ao Programa de Pós-Graduação em Fisiologia Humana do Instituto de Ciências Biomédicas da Universidade de São Paulo, para obtenção do Título de Mestre em Ciências. 


\section{Efeito da suplementação com zinco na evolução da resistência à insulina induzida por dieta hiperlipídica em camundongos}

Dissertação apresentada ao Programa de Pós-Graduação em Fisiologia Humana do Instituto de Ciências Biomédicas da Universidade de São Paulo, para obtenção do Título de Mestre em Ciências.

Área de Concentração: Fisiologia Humana

Orientador: Dr. Fernando Rodrigues de Moraes

Abdulkader

Versão corrigida. A versão original eletrônica encontra-se disponível tanto na Biblioteca do ICB quanto na Biblioteca Digital de Teses e Dissertações da USP (BDTD).

São Paulo

2016 


\section{DADOS DE CATALOGAÇÃO NA PUBLICAÇÃO (CIP)}

Serviço de Biblioteca e Informação Biomédica do

Instituto de Ciências Biomédicas da Universidade de São Paulo

reprodução não autorizada pelo autor

\section{Capetini, Vinícius Cooper.}

Efeito da suplementação com zinco na evolução da resistência à insulina induzida por dieta hiperlipídica em camundongos / Vinícius Cooper Capetini. -- São Paulo, 2016.

Orientador: Prof. Dr. Fernando Rodrigues de Moraes Abdulkader.

Dissertação (Mestrado) - Universidade de São Paulo. Instituto de Ciências Biomédicas. Departamento de Fisiologia e Biofísica. Área de concentração: Fisiologia Humana. Linha de pesquisa: Suplementação com zinco e homeostase glicêmica.

Versão do título para o inglês: Effects of zinc supplementation on the development of insulin resistance induced by high fat diet in mice.

$\begin{array}{llll}\text { 1. Zinco 2. Diabete melito } & 3 \text {. Insulina } & 4 \text {. Resistência à insulina }\end{array}$ I. Abdulkader, Prof. Dr. Fernando Rodrigues de Moraes II. Universidade de São Paulo. Instituto de Ciências Biomédicas. Programa de PósGraduação em Fisiologia Humana III. Título. 
Candidato(a):

Título da Dissertação:

Orientador(a):
Vinícius Cooper Capetini.

Efeito da suplementação com zinco na evolução da resistência à insulina induzida por dieta hiperlipídica em camundongos.

Prof. Dr. Fernando Rodrigues de Moraes Abdulkader.

A Comissão Julgadora dos trabalhos de Defesa da Dissertação de Mestrado, em sessão pública realizada a .... considerou
( ) Aprovado(a)
( ) Reprovado(a)

Examinador(a): Assinatura:

Nome:

Instituição:

Examinador(a): Assinatura:

Nome:

Instituição:

Examinador(a): Assinatura:

Nome:

Instituição: 


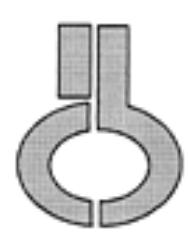

UNIVERSIDADE DE SÃO PAULO

INSTITUTO DE CIËNCIAS BIOMÉDICAS

Cidade Universitária "Armando de Salles Oliveira"

Av. Prof. Lineu Prestes, 2415 - CEP. 05508-000 Såo Paulo, SP Brasil

Telefone :(55) (011) 3091.7733 - e-mail: cep@icb.usp.br

\section{Certificado}

Certificamos que o protocolo registrado sob $n^{\circ} 09$ nas fls. 15 do livro 03 para uso de animais em experimentação, sob a responsabilidade do $\operatorname{Prof(a)} \operatorname{Dr}(a)$ ) Fernando Rodrigues de Moraes Abdulkader, Coordenador (a) da Linha de pesquisa "Efeito da suplementação com zinco sobre a função de ilhotas pancreáticas e resposta à insulina de camundongos C57BL/6 submetidos à dieta hiperlipídica" do qual participam o(s) aluno(s) Vinicius Cooper Capetini, está de acordo com os Princípios Éticos de Experimentação Animal adotado pela Sociedade Brasileira de Ciência de Animais de Laboratório (SBCAL) e foi aprovado pela COMISSÃO DE ÉTICA NO USO DE ANIMAIS (CEUA) em 25.02.2014, com validade de 4 anos.

São Paulo, 27 de fevereiro de 2014.
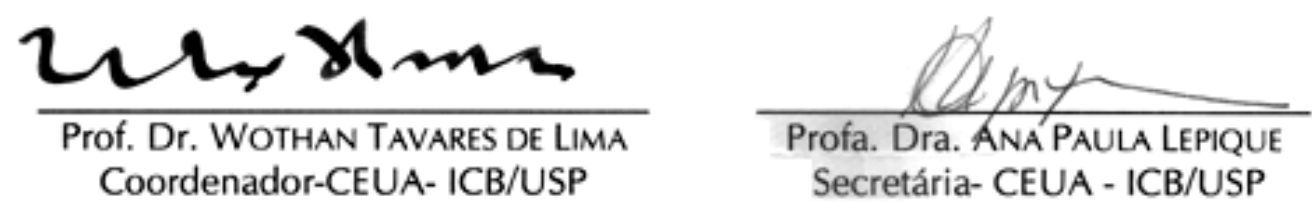
Aos meus pais, por todo o trabalho, a honestidade e o carinho com que me educaram, não medindo esforços para que eu chegasse até aqui e conquistasse os meus sonhos. 


\section{AGRADECIMENTOS}

A Deus por ter me dado à oportunidade de chegar até aqui e me sustentado desde o início desse sonho, se mostrando sempre presente em todos os momentos.

À Luiza Liparizi, Dr. Sebastião Fosse, Dr. Daniel Lidoino e Maria Aparecida Giri que me concederam a licença do meu cargo de nutricionista para cursar o mestrado.

Ao professor Dr. Fernando Abdulkader, por ter aberto as portas do seu laboratório e por sua orientação, me fazendo sempre pensar e não me conter com respostas prontas, o que em muito contribuiu para o meu conhecimento científico e a construção deste trabalho.

Á todos os integrantes, ou que fizeram parte, do Laboratório de Biofísica de Membranas: Andressa Costa, Daniel Blanc, Juan Herts, Eduardo Rebelato, Pedro Modena e Amanda Gomes, que me ajudaram durante o decorrer do curso, me ensinando técnicas e/ou colaborando com o desenvolvimento do meu projeto.

Aos professores Dr. Angelo Carpinelli e Dr. Rui Curi, por terem permitido à realização de muitos dos meus experimentos em seus respectivos laboratórios, disponibilizando apoio técnico e o uso de equipamentos e reagentes, além de todo o conhecimento compartilhado.

Aos integrantes, ou que fizeram parte, do Laboratório de Fisiologia Celular: Diogo Vasconcelos, Sandro Hirabara e Amanda Martins, que realizaram grande parte dos experimentos com o músculo sóleo e por terem compatilhado os seus conhecimentos. Ao técnico Gilson Murata pelo auxílio no uso dos equipamentos e a disponibilização dos reagentes necessários para a realização desses experimentos.

Aos integrantes, ou que fizeram parte, do Laboratório de Secreção de Insulina: Maíra Valle, Patrícia Riva, Daniel Simões, Katherine Veras, Camila Lucena e Hilton Kenji, por terem cada um com sua experiência me auxiliado em muitos dos meus experimentos no decorrer do curso.

Aos integrantes, ou que fizeram parte, do Laboratório de Metabolismo e Endocrinologia: Bruna Lins, Helayne de Freitas e Maristela Mitiko, por terem me apresentado inicialmente a técnica de Wersten Blot. E Lucinana Tocci e Aline David que me ensinaram passo-a-passo o teste intraperitoneal de tolerância à insulina.

À professora Dra. Carla Oliveira por ter permitido por muitas vezes o preparo das rações em seu laboratório, ter disponibilizado a balança e o polytron sempre que preciso e ter compatilhado seu conhecimento. 
À professora Dra. Andréia Torrão e Dra. Fernanda Ortis por ter permitido a revelação de muitas membranas em seus respectivos laboratórios e pela disponibilização de reagentes quando necessário.

Ao professor Dr. Ubiratan Machado por ter permetido à utilização da centrifuga e do espectrofotômetro.

Ao professor Dr. Willian Festuccia pela ajuda na solução das dúvidas em relação à ração ofertada aos animais.

À professora Dra. Luciana Rossoni pelas sugestões que também contribuíram para realização dos experimentos.

Aos integrantes da banca do exame de qualificação: Dr. Ubiratan Machado, Dra. Fernanda Ortis e Dra. Silvana Bordin, por toda a correção necessária e pelas sugestões que em muito contribuíram para a conclusão desse trabalho e principalmente o meu crescimento profissifional.

A todos os funcináios do ICB, principalmente da secretaria e da bilbioteca, por toda a colaboração e disposição em ajudar sempre que necesário. E aos demais funcionários do departamento que também nos prestam serviços com gentileza, facilitando nossas atividades diárias.

À Suliana e Regiane, pela amizade e companherismo.

Àqueles que, involuntariamente, foram esquecidos de serem citados, mas que também contribuíram para a realização desse trabalho.

À CAPES pelo apoio finaceira.

A todos, MUITO OBRIGADO! 
"Mesmo quando um pássaro está caminhando, ele pode sentir que tem asas" 


\section{RESUMO}

CAPETINI, V. C. Efeito da suplementação com zinco na evolução da resistência à insulina induzida por dieta hiperlipídica em camundongos. 2016. 75 f. Dissertação (Mestrado em Fisiologia Humana) - Instituto de Ciências Biomédicas, Universidade de São Paulo, São Paulo, 2016.

O aumento da prevalência do diabete melito do tipo 2 (DM2) é intenso e implica ampla busca pela prevenção e tratamento da doença, que se caracteriza por uma resistência a insulina e por defeitos na secreção da mesma. Estudos têm mostrado a participação do zinco na síntese, secreção e via de sinalização da insulina. Este trabalho objetivou analisar o mecanismo de ação do zinco no controle da secreção de insulina e no controle glicêmico, de modo a entender se a suplementação com o zinco previne ou retarda a manifestação do DM2. O protocolo de experimentação animal foi aprovado pela CEUA-ICB (USP). Camundongos machos $\mathrm{C} 57 \mathrm{BL} / 6$ foram divididos em 4 grupos experimentais: ração controle (NFD); ração controle suplementada com $\mathrm{ZnCl}_{2}$ (NFDZ); ração hiperlipídica (HFD); e ração hiperlipídica suplementada com $\mathrm{ZnCl}_{2}$ (HFDZ). A massa corporal, a ingestão de ração e água e a glicemia foram acompanhadas semanalmente. Testes intraperitoneais de tolerância à glicose (ipGTT) e à insulina (ipITT) foram realizados na 14a semana de tratamento. Completadas as 15 semanas de tratamento a glicemia, a insulinemia e a zincemia foram analisadas, sendo a resistência à insulina e a atividade da célula $\beta$ avaliadas pelos métodos HOMA-IR e HOMA- $\beta$, respectivamente. Ilhotas pancreáticas foram isoladas e incubadas em diferentes concentrações de glicose para avaliar a secreção de insulina. Parte dos animais tiveram o músculo sóleo incubado com e sem insulina $(10 \mathrm{mU} / \mathrm{mL})$ para o teste de captação e metabolismo de glicose e outra parte para a análise do conteúdo e fosforilação das proteínas AKT e GSK3- $\beta$, que também foram avaliadas no fígado. Os dados (média \pm SEM) foram analisados por Two way ANOVA com pós-teste de Bonferroni ou por teste $\mathrm{t}$ de Student $(P \leq 0,05)$. Os grupos HFD e HFDZ apresentaram um ganho de massa corporal (g) maior do que os grupos NFD e NFDZ, mas a suplementação com $\mathrm{ZnCl}_{2}$ não alterou o ganho de massa corporal, a constante de decaimento de glicose $\left(\% \mathrm{~min}^{-1}\right)$, o índice HOMA-IR (UA), a captação e o metabolismo de glicose no músculo e o conteúdo e a fosforilação (\%) de AKT e GSK3- $\beta$ no músculo e no fígado. Entretanto, em comparação ao grupo HFD, o grupo HFDZ apresentou menor glicemia (mg/dL) e menor área sob a curva no ipGTT (min.mg/dL) e um aumento parcial do índice $H O M A-\beta(\%)$, apesar de não melhorar a secreção de insulina em ilhotas isoladas e estimuladas com glicose (ng/ilhota/h). Portanto, a suplementação com zinco melhorou a disfunção glicêmica induzida por ração hiperlipídica, sem no entanto afetar a resistência à insulina ou a secreção de insulina por ilhotas isoladas.

Palavras chaves: Zinco. Diabete melito. Insulina. Resistência à insulina. 


\section{ABSTRACT}

CAPETINI, V. C. Effects of zinc supplementation on the development of insulin resistance induced by high fat diet in mice. 2016. 75 p. Masters Thesis (Human Physiology). - Instituto de Ciências Biomédicas, Universidade de São Paulo, São Paulo, 2016.

The increase in prevalence of type 2 diabetes mellitus (DM2) is intense and implies broad quest for prevention and treatment of disease, characterized by insulin resistance and defects in secretion thereof. Studies have shown a role of zinc in the synthesis, secretion and insulin signaling pathway. This study aimed to analyze the mechanism of action of zinc in the control of insulin secretion and glucose control in order to understand whether supplementation with zinc prevents or delays the manifestation of DM2. The protocol of animal experimentation it was approved by CEUA-ICB (USP). Male mice C57BL/6 were divided en 4 groups: control diet (NFD); control diet supplemented with $\mathrm{ZnCl}_{2}$ (NFDZ); high fat diet (HFD); and high fat diet supplemented with $\mathrm{ZnCl}_{2}$ (HFDZ). Body weight, feed intake and water and the glucose levels were monitored weekly. Intraperitoneal glucose tolerance test (ipGTT) and insulin (ipITT) were performed at the 14th week of treatment. Completing the 15 weeks of the treatment glycemia, insulinemia and zincemia were analyzed, being insulin resistance and beta cell activity was evaluated by HOMA-IR methods and HOMA- $\beta$, respectively. Pancreatic islets were isolated and incubated with different glucose concentrations to assess insulin secretion. Some of the animals had the soleus muscle incubated with and without insulin $(10 \mathrm{mU} / \mathrm{mL})$ for the uptake and metabolism of glucose and other part to analyze the content and the phosphorylation of AKT and GSK3- $\beta$ proteins, which were also assessed in the liver. The data (mean \pm SEM) were analyzed by Two way ANOVA with Bonferoni post-test or Student's t test $(P \leq 0,05)$. The HFD and HFDZ groups had a body mass gain (g) greater than NFD and NFDZ groups, but supplementation with $\mathrm{ZnCl}_{2}$ didn't alter body weight, glucose decay constant $\left(\% \mathrm{~min}^{-1}\right)$, the HOMA-IR index (AU), the uptake and metabolism of glucose in muscle and the content and phosphorylation (\%) AKT and GSK3- $\beta$ in muscle and liver. However in comparison to the HFD group, the HFDZ group showed lower blood glucose $(\mathrm{mg} / \mathrm{dL})$ and lower area under the curve in the ipGTT (min.mg/dL) and a partial increase in index HOMA- $\beta$ (\%), despite not enhance insulin secretion in islets isolated and stimulated with glucose (ng/islet/h). Therefore, zinc supplementation improves glucose dysfunction induced by high fat diet, without nonetheless affecting insulin resistance and insulin secretion by isolated islets.

Keywords: Zinc. Diabetes mellitus. Insulin. Insulin resistance. 


\section{LISTA DE ILUSTRAÇÕES}

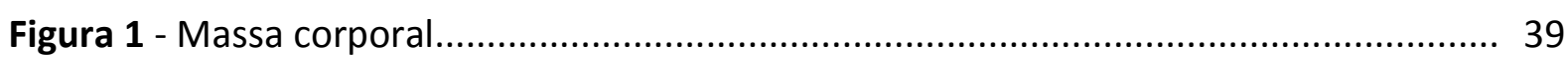

Figura 2 - Área sob a curva (AUC) do ganho de massa corporal..................................... 40

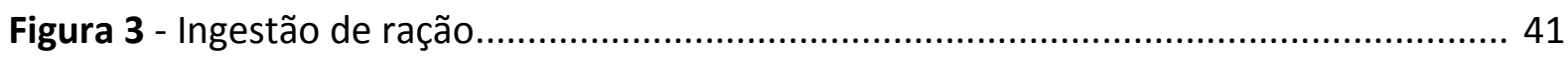

Figura 4 - Evolução da glicemia dos animais medida entre 8 e 9 horas durante as 15 semanas de tratamento.

Figura 5 - Glicemia e insulinemia após privação alimentar de 8 horas ao final do tratamento.

Figura 6 - Homeostasis Model Assessment (HOMA) ao final do tratamento

Figura 7 - Teste intraperitoneal de tolerância à glicose (ipGTT)

Figura 8 - Teste intraperitoneal de tolerância à insulina (ipITT)

Figura 9 - Ensaio estático de secreção de insulina por ilhotas isoladas estimuladas por glicose

Figura 10 - Efeito da suplementação com $\mathrm{ZnCl}_{2}$ sobre o conteúdo e a fosforilação de AKT e GSK3- $\beta$ no fígado de animais controles e suplementados com $\mathrm{ZnCl}_{2}$

Figura 11 - Efeito da suplementação com $\mathrm{ZnCl}_{2}$ sobre o conteúdo e a fosforilação de AKT e GSK3- $\beta$ no músculo sóleo, com (+Ins) e sem (-Ins) estímulo de insulina, de animais controles e suplementados com $\mathrm{ZnCl}_{2}$

Figura 12 - Captação e metabolismo de glicose com (+ins) e sem (-ins) estímulo de insulina em músculo sóleo isolado de animais controles e suplementados com $\mathrm{ZnCl}_{2}$ 


\section{LISTA DE TABELAS}

Tabela 1 - Composição e valor calórico das rações normolipídica e hiperlipídica, adaptado de Reeves, Nielsen e Fahey (1993).

Tabela 2 - Massa corporal, ingestão de ração, ingestão hídrica, ingestão de zinco presente na ração, suplementação com $\mathrm{ZnCl}_{2}$ e ingestão calórica dos animais dos grupos NFD e HFD controle e suplementados com $\mathrm{ZnCl}_{2}$.

Tabela 3 - Glicemia, insulinemia e zincemia após privação alimentar, índices HOMA-IR e $\beta$, constante de decaimento de glicose no ipITT e área sob a curva da glicemia no ipGTT dos animais dos grupos NFD e HFD controle e suplementados com $\mathrm{ZnCl}_{2}$ 


\section{LISTA DE ABREVIATURAS E SIGLAS}

\begin{tabular}{|c|c|}
\hline AKT & Serine/threonine-specific protein kinase / Proteína quinase B (PKB) \\
\hline$A / N$ & American Institute of Nutrition \\
\hline CRIP & Proteína intestinal rica em cisteína \\
\hline Cu-Zn SOD & Cobre-zinco superóxido dismutase \\
\hline DM & Diabete melito \\
\hline DM1 & Diabete melito do tipo 1 \\
\hline DM2 & Diabete melito do tipo 2 \\
\hline DNA & Deoxyribonucleic Acid \\
\hline Glis3 & GLIS family zinc finger 3 \\
\hline GLUT4 & Transportador de glicose do tipo 4 \\
\hline GSK3- $\beta$ & Glicogênio sintase quinase $3 \beta$ \\
\hline HDL & High Density Lipoprotein \\
\hline HEK-293 & Células humanas embrionárias de rim \\
\hline HFD & High Fat Diet \\
\hline HFDZ & High Fat Diet Zinc \\
\hline HOMA-IR & Homeostasis model assessment - Insulin Resistance \\
\hline$H O M A-\beta$ & Homeostasis model assessment - $\beta$-cell \\
\hline HUT-78 & Linhagem celular de linfócito $T$ \\
\hline INS-1E & Insulin-secreting cell lines $1 E$ \\
\hline ipGTT & Teste intraperitoneal de tolerância à glicose \\
\hline iplTT & Teste intraperitoneal de tolerância à insulina \\
\hline IRS & Substrato receptor de insulina \\
\hline KITT & Constante de decaimento de glicose \\
\hline MT & Metalotioneína \\
\hline MT1 & Metalotioneína 1 \\
\hline NFD & Normal Fat Diet \\
\hline NFDZ & Normal Fat Diet Zinc \\
\hline p-AKT & Phospho-AKT \\
\hline p-GSK-3 $\beta$ & 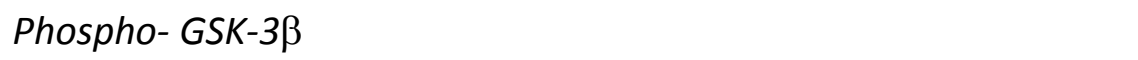 \\
\hline PI3-K & Fosfatidilinositol-3-quinase \\
\hline Rab & GTPase activating protein \\
\hline RNA & Ribonucleic Acid \\
\hline $\mathrm{SH} 2$ & Homologia Src2 \\
\hline ST18 & Suppression of Tumorigenicity 18 \\
\hline TBS & Tris-buffered saline \\
\hline TBST & Tris-buffered saline with tween \\
\hline TNF- $\alpha$ & Fator de Necrose Tumoral alfa \\
\hline Tshz1 & Transcription factor teashirt zinc finger \\
\hline ZIP & Zrt-, Irt-like proteins \\
\hline
\end{tabular}


$\mathrm{ZnCl}$

Cloreto de Zinco

$\mathrm{ZnF}$

Zinc finger

$\mathrm{ZnT}$

Zinc tranporter 


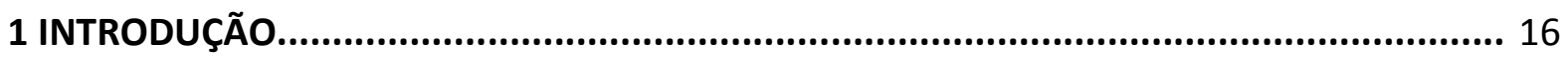

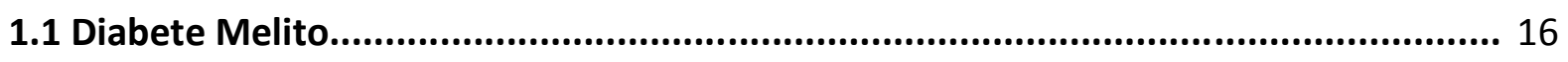

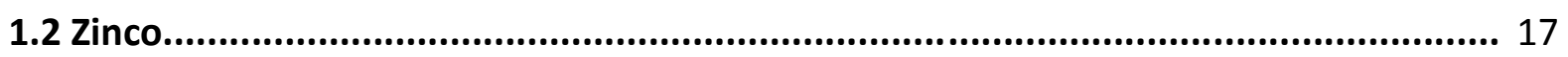

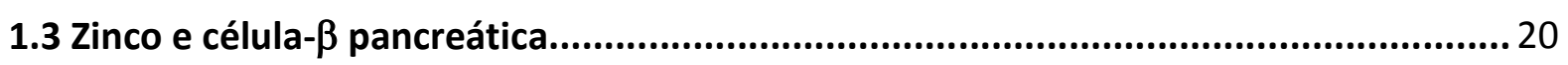

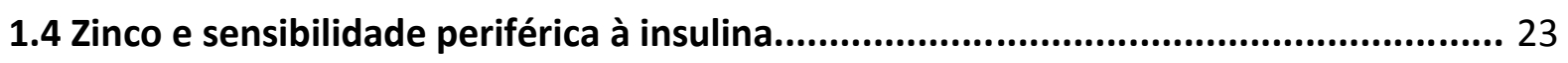

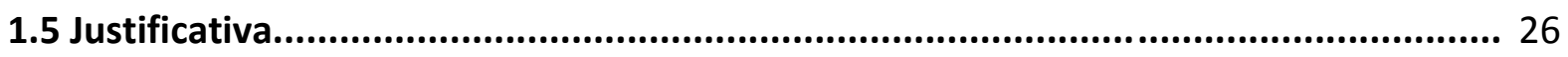

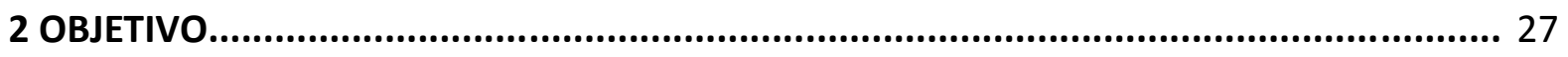

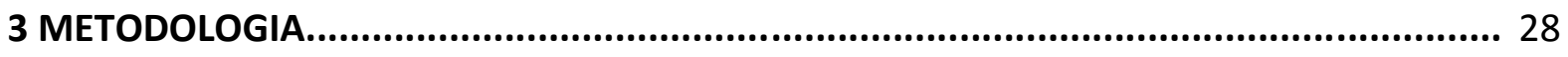

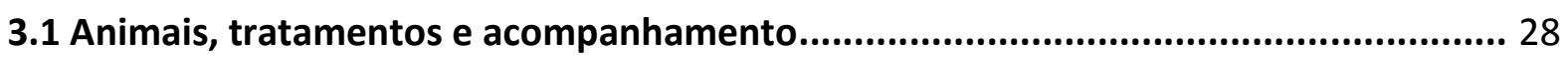

3.2 Teste intraperitoneal de tolerância à glicose........................................................ 31

3.3 Teste intraperitoneal de tolerância à insulina................................................... 31

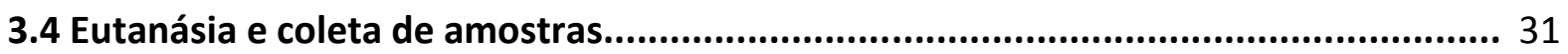

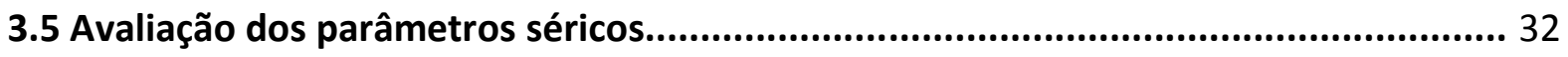

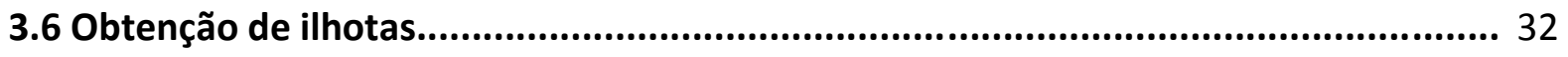

3.7 Secreção estática de insulina por ilhotas isoladas................................................. 33

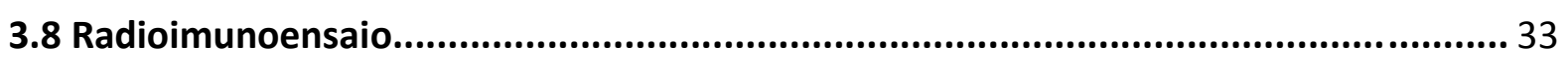

3.9 Incubação do músculo sóleo com e sem insulina.................................................... 34

3.10 Homogeneização do músculo sóleo e extração de proteínas................................... 34

3.11 Homogeneização do fígado e extração de proteínas............................................... 35

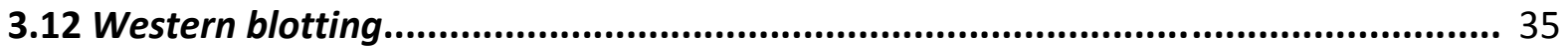

3.13 Captação e metabolismo da glicose no músculo sóleo isolado................................ 36

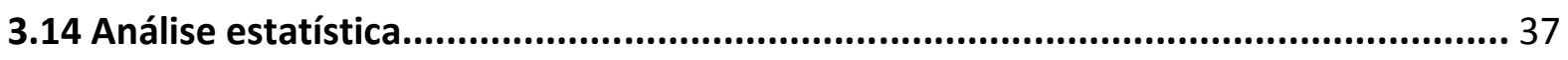

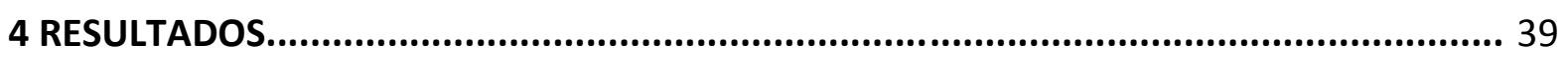

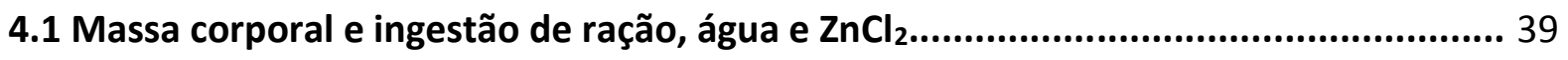

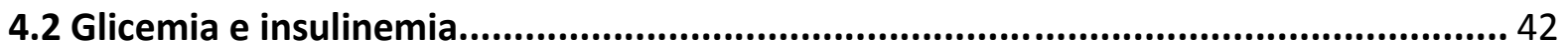

4.3 Homeostasis Model Assessment (HOMA).............................................................. 45

4.4 Teste intraperitoneal de tolerância à glicose.......................................................... 45

4.5 Teste intraperitoneal de tolerância à insulina................................................... 46

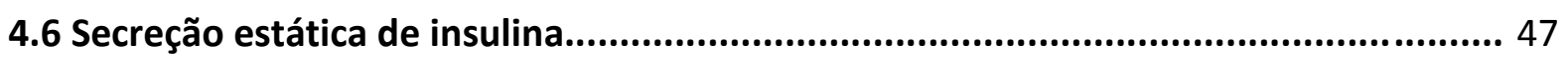

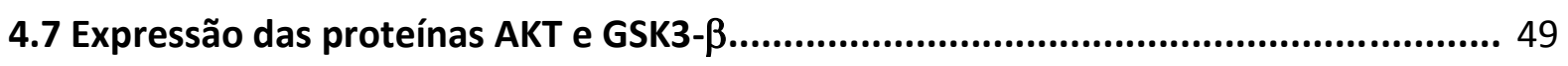

4.8 Captação e metabolismo de glicose.................................................................. 51

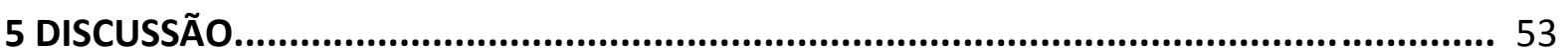

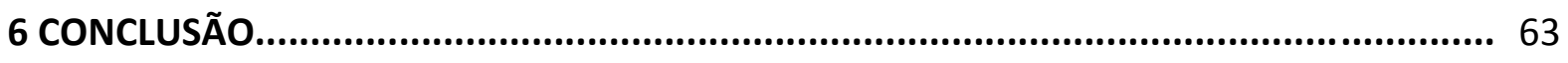

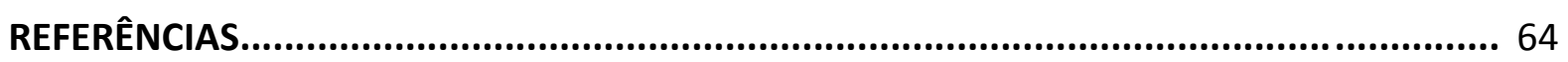




\section{INTRODUÇÃO}

\subsection{Diabete Melito}

O diabete melito (DM) continua a ser um crescente problema de saúde pública em países como a China, a Índia, os Estados Unidos, o Brasil e a Rússia. Em 2015 o número de diabéticos no Brasil foi estimado em 14,3 milhões entre a faixa etária de 20 e 79 anos e esse número pode chegar a 23,3 milhões até 2040 (INTERNATIONAL DIABETES FEDERATION, 2015). Apesar do DM ser uma doença de origem e classificação múltipla, destacam-se como os principais responsáveis pelo aumento de sua prevalência, o aumento do sedentarismo, da obesidade, do envelhecimento e da urbanização em países em desenvolvimento, onde os recursos são ainda mais escassos para combater os problemas clínicos associados à doença. As buscas por ações preventivas e medidas que contrariem a tendência de aumento dessa prevalência são de grande relevância para a saúde pública e a economia em países como o Brasil (GUARIGUATA et al., 2014).

É possível que o DM tenha causado 5 milhões de mortes no mundo em 2015, sendo responsável por $5 \%$ a $20 \%$ do gasto total com a saúde na maioria dos países, com um custo mundial estimado em 673 bilhões de dólares (INTERNATIONAL DIABETES FEDERATION, 2015). No Brasil, essa doença foi responsável por 57,8 mil óbitos em 2011, representando 5,3\% do total de óbitos e uma taxa de mortalidade de 30,1 óbitos por 100 mil habitantes (MALTA et al., 2014; BRASIL, 2012), estando entre as principais causas de mortalidade e de hospitalizações no Sistema Único de Saúde (SUS) (SCHMIDT et al., 2011), sendo responsável por 7,3\% do total de internações no Brasil em 2012 (BRASIL, 2013). Estima-se que o Brasil tenha gastado 21,8 bilhões de dólares com o DM em 2015 (INTERNATIONAL DIABETES FEDERATION, 2015).

O DM ocorre quando há hiperglicemia devido à falta de insulina, um hormônio peptídico secretado pelas células $\beta$ pancreáticas presentes nas ilhotas de Langerhans, e/ou quando há uma resistência à ação desse hormônio em tecidos periféricos, como no músculo, fígado e no tecido adiposo, havendo uma diminuição na captação de glicose. De modo geral, essa enfermidade é classificada em dois tipos: Diabete melito tipo 1 (DM1) e Diabete melito tipo 2 (DM2). O DM1 representa de 7 a 12\% dos casos da doença (AMERICAN DIABETES ASSOCIATION, 2015; INTERNATIONAL DIABETES FEDERATION, 2015), o qual resulta de uma 
predominante destruição autoimune das células $\beta$ resultando em pouca ou nenhuma síntese de insulina (DANEMAN, 2006; DEVENDRA; LIU; EISENBARTH, 2004). Por outro lado, o DM2 é responsável por mais de 90\% dos casos de DM (AMERICAN DIABETES ASSOCIATION, 2015; INTERNATIONAL DIABETES FEDERATION, 2015), sua patogênese é complexa e envolve a interação de fatores genéticos e ambientais, mas não apresenta um componente autoimune e desenvolve-se predominantemente devido a resistência ao efeito da insulina em algumas células alvo (HALBAN et al., 2014) e pode desencadear a destruição progressiva das células $\beta$ (BERGMANet al., 2002). Com a intolerância à glicose resultante, em longo prazo, ambos os tipos de DM podem ocasionar complicações tardias em diversos sistemas incluindo doenças macrovasculares (dislipidemia e hipertenção) e microvasculares (nefropatia, retinopatia e neuropatia) (BROWNLEE et al., 2010). Portanto, o DM é considerado uma das principais causas de doenças cardiovasculares, cegueira, insuficiência renal e amputações de membros inferiores, sendo responsável por gastos significativos em saúde no Brasil e em outros países, além de causar importante redução da capacidade de trabalho e da expectativa de vida entre as populações (INTERNATIONAL DIABETES FEDERATION, 2015).

Atualmente, o tratamento do DM é baseado na modificação do estilo de vida, incluindo alterações dietéticas, redução da massa corporal e prática de exercício físico, além da administração de antihiperglicemiantes orais ou insulina. Estudos com várias drogas no tratamento dessa doença e suas complicações vêm sendo realizados, assim como é explorado o efeito terapêutico da suplementação com o zinco em algumas pesquisas (GUPTA et al., 1998; JAYAWARDENA et al., 2012).

\subsection{Zinco}

O zinco é um microelemento essencial para a saúde humana e está envolvido com o crescimento, o sistema imunológico e a cognição, sendo necessário para um vasto número de reações celulares. Existem mais de 2.000 fatores de transcrição dependentes de zinco e esse mineral atua como cofator em processos antioxidantes, antinflamatórios e antiapoptóticos, além de participar do metabolismo de carboidratos, proteínas e lipídios e, da síntese ou degradação de ácidos nucléicos (MIAO et al., 2013; STEFANIDOU et al., 2006), assim como tem sido evidenciado sua participação na síntese, secreção e/ou ação de alguns hormônios, como a insulina (DODSON; STEINER, 1998) e a leptina (CHEN et al., 2001). De 
modo geral suas funções são agrupadas em: (1) estrutural, auxiliando na manutenção da forma e disposição espacial de proteínas e enzimas; (2) enzimática, contribuindo com a atividade catalítica das enzimas e do balanço acidobásico sanguíneo; e (3) reguladora, atuando na atividade dos neurônios e na memória (CHASAPIS et al., 2012).

As principais fontes dietéticas de zinco são as de origem animal, como ostras, fígado, carnes, caranguejo e ovos (GALLAGHER, 2010; SANDSTRÖM, 1997). Os cereais integrais têm um alto teor de zinco, mas a presença de fitato (ácido fítico ou hexafosfato de mio-inositol) diminui a biodisponibilidade dessas fontes, devido à sua propriedade de associar-se ao mineral diminuindo sua absorção (SANDSTRÖM, 1997; SILVA; SILVA, 1999). A ingestão diária recomendada de zinco para crianças maiores, adolescentes e adultos é de 8 a $11 \mathrm{mg} / \mathrm{dia}$ dependendo do gênero, o limite superior tolerável de ingestão estabelecido é de $40 \mathrm{mg} / \mathrm{dia}$ para adultos (GALLAGHER, 2010).

A dieta deficiente em zinco, comum em países em desenvolvimento, está associada com o retardo no crescimento, falta de apetite, dermatites, alopecia, hipogonadismo, baixa atividade imunológica (PRASAD, 1985) e prejuízos no metabolismo da glicose (ARQUILLA et al., 1978; QUARTERMAN; MILLS; HUMPHRIES, 1966). Por outro lado, o zinco alimentar não apresenta efeitos tóxicos e sua ingestão acima dos limites estabelecidos não é comum. Apesar do potencial tóxico desse mineral ser baixo, devido à eficiência dos mecanismos homeostáticos que controlam o seu metabolismo (PLUM; RINK; HAASE, 2010), a toxicidade aguda por ingestão de zinco está relacionada ao surgimento de náuseas, paladar metálico, vômitos, cólicas abdominais e diarreia (SAPER; RASH, 2009).

O zinco é absorvido preferencialmente no jejuno e sua captação pelas células da superfície do epitélio intestinal é regulada homeostaticamente por proteínas especializadas responsáveis pelo influxo e efluxo desse mineral, bem como por sua distribuição intracelular. O transporte ativo é saturável em altas concentrações desse mineral no lúmen intestinal e se torna mais eficiente durante períodos de baixa ingestão. Por outro lado, o transporte passivo é um mecanismo de difusão proporcional à concentração de zinco no lúmen (SALGUEIRO et al., 2000).

Dentre os transportadores duas classes de proteínas já foram identificadas. Os transportadores de zinco da família ZIP (Zrt-, Irt-like proteins) são responsáveis pelo influxo desse mineral para o citoplasma e os ZnT (Zinc tranporter), pela extrusão do cátion para fora do citoplasma ou dos compartimentos intracelulares (FUKADA et al., 2011). Nas células 
intestinais já foram identificados os ZIP4, ZIP5, ZNT1, ZNT2, ZNT4, ZNT5, ZNT6 e ZNT7 (DUFNER-BEATTIE et al., 2003; DUFNER-BEATTIE et al., 2004; LIUZZI et al., 2003; MCMAHON; COUSINS, 1998; YU; KIRSCHKE; HUANG, 2007).

A compartimentalização do zinco na célula intestinal depende da regulação de metalotioneínas (MT) e de proteínas intestinais ricas em cisteína (CRIP) (HEMPE; COUSINS, 1992). As MT são proteínas de baixo peso molecular que se ligam ao zinco e a outros metais, como o cobre e o selênio. Elas controlam o reservatório de zinco para uso em atividades celulares e simultaneamente protegem a célula contra a toxicidade desse mineral (VASAK et al., 2011). O zinco está presente em mais de 300 metaloproteínas (MIAO et al., 2013). A CRIP funciona como uma proteína de transporte intracelular que direciona o zinco até a membrana basolateral onde o mineral será transportado para o plasma. Após o zinco ser transportado para o interior da célula intestinal a MT liga-se transitoriamente a esse metal e o libera gradativamente no citoplasma, podendo então associar-se a CRIP, de modo a regular a ligação do zinco a essa proteína (HEMPE; COUSINS, 1992). Após o processo de absorção, o zinco é liberado dos enterócitos na circulação mesentérica e captado da circulação portal pelo fígado, sendo a maior parte redistribuída para outros tecidos (COUSINS, 1985).

O transporte de zinco no plasma ocorre principalmente pela albumina, mas também ocorre em menor quantidade pela transferrina e a $\alpha 2$-macroglobulina (CHASAPIS et al., 2012). O zinco plasmático é metabolicamente ativo e varia principalmente em resposta à sua ingestão dietética. A excreção desse mineral em indivíduos normais dá-se quase que totalmente através das secreções pancreáticas e intestinais (COUSINS, 1985).

O zinco é encontrado em todos os tecidos do corpo humano, sendo o microelemento intracelular mais abundante do organismo depois do ferro (KING; SHAMES; WOODHOUSE, 2000). O corpo possui apenas aproximadamente 2 a 4 g de zinco (JANSEN; KARGES; RINK, 2009), sendo que $85 \%$ do seu total são encontrados nos músculos e ossos (KING; SHAMES; WOODHOUSE, 2000). A concentração desse mineral por grama de peso é mais elevada na próstata com aproximadamente $200 \mu \mathrm{g} / \mathrm{g}$, em seguida, no pâncreas com aproximadamente $140 \mu \mathrm{g} / \mathrm{g}$, e no músculo com cerca de $50 \mu \mathrm{g} / \mathrm{g}$, enquanto que no plasma é de cerca de $14 \mathrm{a}$ $16 \mu \mathrm{M}$ de zinco total que é distribuído para as células (JANSEN; KARGES; RINK, 2009). A nível celular, as concentrações de zinco total em células humanas são 200 a $300 \mu \mathrm{M}$ (MARET, 2015), sendo que $40 \%$ está localizado no núcleo, $50 \%$ no citoplasma, organelas e vesículas especializadas e o restante na membrana celular (TAPIERO; TEW, 2003). 
Curiosamente, pacientes com DM2 apresentam uma diminuição na concentração de zinco no plasma, em conjunto com a hiperzincúria (KINLAW et al., 1983). Interessantemente, a suplementação com o zinco foi associada a uma melhora do controle glicêmico no DM1 e 2 (JANSEN; KARGES; RINK, 2009; TAYLOR, 2005) e alta concentração de zinco na ração também foi associada a uma redução dos níveis plasmáticos de glicose em ratos diabéticos (OKAMOTO et al., 2011).

\subsection{Zinco e célula- $\beta$ pancreática}

No pâncreas, o zinco está envolvido na síntese, armazenamento e secreção de insulina (DODSON; STEINER, 1998). Essa compreensão nasceu quando Scott (1934) descobriu que a adição do zinco em uma solução tampão de fosfato contendo insulina induziu a formação de cristais de insulina. Mais tarde, Scott e Fisher (1938) observaram que a concentração de zinco no pâncreas de indivíduos diabéticos era menor do que em indivíduos saudáveis, mas que não havia diferença quanto à concentração de zinco encontrado no fígado, levantando à possibilidade de que, pelo menos, uma fração do zinco pancreático poderia estar relacionada com o processamento da insulina nas células $\beta$

Atualmente é sabido que um desequilíbrio no controle homeostático de zinco parece causar um importante prejuízo na secreção da insulina (NYGAARD et al., 2014). A hipozincemia está associada com a redução no teor de insulina em células $\beta$ (SONDERGAARD et al., 2003). A deficiência desse mineral em ratos foi relacionada com a deficiência na secreção de insulina e menor sensibilidade periférica a esse hormônio (ARQUILLA et al., 1978; QUARTERMAN; MILLS; HUMPHRIES, 1966). Entretanto, um aumento local na concentração desse mineral pode ter um efeito citotóxico sobre as células $\beta$, causando a morte celular por apoptose (NYGAARD et al., 2014).

Nos grânulos secretórios, a insulina está associada ao zinco em uma estequiometria de 2 íons de zinco para 6 moléculas de insulina, formando um complexo que no meio extracelular será dissolvido em moléculas de insulina e zinco após ser secretado e ao longo da circulação sanguínea. É sugerido que a associação da insulina ao zinco estabiliza e evita a degradação dos hexâmeros de insulina, reduzindo a taxa de proteólise e protegendo esse hormônio da ação de enzimas proteolíticas (EMDIN et al., 1980; DUNN, 2005). Pesquisas a respeito do zinco demonstram que os grânulos secretórios contêm um terço do zinco da 
ilhota (FIGLEWICZ et al., 1984), sendo sua concentração no grânulo de aproximadamente 20 mM (FOSTER et al., 1993). Após a estimulação com glicose, a concentração de zinco cosecretado para o espaço extracelular pode atingir $475 \mu \mathrm{M}$ (KIM et al., 1995). Desse modo, durante a exocitose, o zinco é secretado junto à insulina, causando um aumento deste mineral no espaço extracelular, podendo ser transportado de volta para o interior da célula que o secretou ou de células vizinhas (FRANKLIN et al., 2005).

A concentração de zinco citoplasmática em células $\beta$ parece ser fortemente regulada, sendo mantida por volta de pouco menos de 400 pM (BELLOMO; MEUR; RUTTER, 2011). Nas células $\beta$ o nível de zinco livre parece mediar várias vias de sinalização, incluindo cascatas de sinalização apoptótica, sugerindo que esse mineral possa atuar com uma molécula de sinalização e regulação do metabolismo celular e em outras atividades funcionais (SENSI et al., 2009). Estudos recentes mostram que a estimulação por glicose aumenta a concentração e o tráfego de zinco livre em células $\beta$, indicando que essas alterações na concentração de zinco livre em resposta a estímulos externos possam ser um mecanismo para o reestabelecimento da concentração de zinco nos grânulos secretórios de insulina e um mecanismo importante na regulação da disponibilidade de insulina na célula $\beta$ ou sua secreção (BELLOMO; MEUR; RUTTER, 2011; SENSI et al., 2009; SLEPCHENKO, 2012).

A homeostase do zinco em célula $\beta$ pancreática também é dependente dos transportadores ZIP e ZnT. Os principais transportadores da família ZIP encontrados no pâncreas são ZIP1, 3, 4, 5, 7, 10 e 14 (BOSCO et al., 2010). Nas células $\beta$, apesar do limitado conhecimento sobre a função desses transportadores, é sabido que o ZIP4 é expresso na membrana plasmática, desempenhando importante função na homeostase do zinco, permitindo a captação desse mineral pela célula (DUFNER-BEATTIE et al., 2009). Além do ZIP4, o ZIP6, 8 e 14 também foram localizados na membrana plasmática de células $\beta$. Já o ZIP7 foi encontrado na membrana do retículo endoplasmático e de lisossomos (HUANG, 2014).

Os ZnT1, 2, 3, 4, 5, 7, 8, 9, e 10 são os principais transportadores da família ZnT encontrados em diferentes células pancreáticas (BOSCO et al., 2010). O ZnT3, 4 e 5 são expressos em células $\beta$. No entanto, a localização celular do ZnT4 é desconhecida. O ZnT3 e 5 foram localizados em vesículas citoplasmáticas e o ZnT5 também foi encontrado nos grânulos secretórios (HUANG, 2014). O ZnT8 é especificamente expresso nesses grânulos 
secretórios, tendo sido identificados anticorpos que atacam esse transportador no início do desenvolvimento do DM do tipo 1 (SCOTTO et al., 2012). Associada ao DM2 foi também relatada à ocorrência de um polimorfismo de um único nucleotídio (Arg325Trp) desse transportador (HUANG, 2014; SCOTTO et al., 2012; XU et al., 2012). Estudos recentes têm mostrado que esse polimorfismo em seres humanos está relacionado com a diminuição da secreção de insulina (BOESGAARD et al., 2008; PASCOE et al., 2008) e que camundongos diabéticos, db/db e Akita, apresentaram menor expressão do ZnT8 em relação aos camundongos controle (TAMAKI et al., 2009). O ZnT7 está envolvido no transporte de zinco citoplasmático para o complexo de Golgi onde esse mineral pode ser armazenado ou incorporado em proteínas recém-sintetizadas. Em camundongos C57BL/6J a superexpressão do ZnT7 em células $\beta$ aumentou significativamente a concentração e a secreção basal de insulina (HUANG; YAN; KIRSCHKE, 2010).

As MT desempenham um importante controle homeostático do zinco intracelular em células $\beta$ e auxiliam na regulação do estado redox celular (MARET, 2008). As MT liberam o zinco em resposta ao dano oxidativo, uma condição frequentemente encontrada nos tecidos de indivíduos com DM2 (LEE et al., 2003). As principais isoformas dessas proteínas encontradas no pâncreas são as MT1 e MT2 (CAl, 2004). As ilhotas de camundongos transgênicos que não expressavam MT apresentavam um teor semelhante de insulina em comparação com ilhotas de camundongos controle, entretanto, a secreção de insulina basal e estimulada por glicose em ilhotas dos animais que não expressavam as MT foi significativamente menor, sugerindo que as MT são necessárias na modulação da secreção de insulina a partir das células $\beta$ (LAYCHOCK; DUZEN; SIMPKINS, 2000). A síntese de MT foi aumentada com o tratamento de zinco em células $\beta$ e protegeu significativamente contra o DM induzido por estreptozotocina, o que pode estar relacionado com os efeitos protetores das MT no estresse oxidativo muitas vezes presente no DM (CAI, 2004; YANG et al., 1994).

O aumento da expressão da MT e a inibição de caspases e da xantina-oxidase exercendo efeitos antioxidantes e antiapoptóticos, respectivamente, é sugerido estar relacionado com o aumento da concentração de zinco intracelular (BOSCO et al., 2010). Além disso, o zinco desempenha um papel importante na manutenção da integridade estrutural da enzima cobre-zinco superóxido-dismutase (Cu-Zn SOD) presente no citoplasma de células eucarióticas, sendo que a suplementação com zinco aumentou a atividade dessa 
enzima antioxidante in vitro, enquanto que a sua atividade foi diminuída em ratos com deficiência desse mineral (COUDRAY et al., 1992).

Além de estar presente em MT e nas CRIP (HEMPE; COUSINS, 1992), o zinco é um metal fundamental para garantir a estabilidade dos Zinc fingers (ZnF), pequenos domínios proteicos que fazem parte de fatores de transcrição eucarióticos, desempenhando um importante papel no ciclo celular ao se ligarem no DNA e no RNA, regulando a expressão de genes, o metabolismo, a apoptose e outros mecanismos celulares (KRISHNA; MAJUMDAR; GRISHIN, 2003; LAITY; LEE; WRIGHT, 2001). Um estudo recente mostrou que o aumento da expressão de ST18 (Suppressionof Tumorigenicity 18), um ZnF que no pâncreas é expresso apenas nas células endócrinas, induz a apoptose e restringe a replicação de células $\beta$, prejudicando a secreção de insulina (HENRY; CLOSE; BUTEAU, 2014). Por outro lado, a deficiência de outros ZnF, como o transcription factor teashirt zinc finger 1 (Tshz1) pode está envolvida com o surgimento do DM2 (RAUM et al., 2015) e a deficiência de GLIS family zinc finger 3 (Glis3), com o surgimento do DM1, 2 e neonatal (YANG et al., 2009).

\subsection{Zinco e sensibilidade periférica à insulina}

O efeito do zinco na sensibilidade periférica à insulina tem despertado o interesse de muitos pesquisadores. Este mineral possui uma relação com os sinais de membrana na regulação hormonal, que parece melhorar a interação entre hormônios e seus receptores, como no caso da ligação da insulina e seu receptor de membrana em células-alvo (CUNNINGHAM et al., 1990; HAASE; MARET, 2005).

A insulina é o principal regulador do metabolismo e do armazenamento de energia de todo o organismo (POLOZ; STAMBOLIC, 2015). Sua ligação à subunidade $\alpha$ do seu receptor de membrana, composto por duas subunidades $\alpha$ e duas subunidades $\beta$, leva à alteração conformacional e autofosforilação, ativando a atividade tirosina cinase intrínseca do receptor, que fosforila vários substratos proteicos intracelulares, como os substratos do receptor de insulina (IRSs) em tirosina, criando sítios de reconhecimento para moléculas contendo domínios com homologia a $\mathrm{Src2}(\mathrm{SH} 2)$, como a fosfatidilinositol-3-quinase (PI3-K) que é a mediadora das principais ações metabólicas da insulina via efetores "downstream" como a proteína quinase B (AKT) (BOURA-HALFON; ZICK, 2005). Por fosforilação, a AKT inibe a proteína AS160, permitindo que as proteínas Rab (GTPase activating protein) operem 
sobre o tráfego de vesículas que contêm transportadores de glicose do tipo 4 (GLUT4), dependentes de insulina (WATSON; PESSIN, 2007). Após estímulo com insulina a AKT também fosforila e inativa a glicogênio sintase quinase-3 $\beta$ (GSK3- $\beta$ ), o que diminui a taxa de fosforilação da glicogêniosintetase aumentando sua atividade (CROSS et al., 1995). Independente da AKT, a PI3-K ativa a proteína fosfatase 1 que também desfosforila a glicogênio sintetase (BRADY; NAIRN; SALTIEL, 1997). Desfosforilada, a glicogênio sintetase inicia a síntese de glicogênio (BRADY; NAIRN; SALTIEL, 1997; CROSS et al., 1995).

A insulina também diminui a expressão de algumas enzimas hepáticas necessárias para o processo de gliconeogênese e glicogenólise, como a diminuição da expressão do fosfoenolpiruvato carboxicinase (PEPCK) e da glicose-6-fosfatase (G6Pase), respectivamente (PILKIS et al., 1986). Esse hormônio ainda reduz o fornecimento de precursores metabólicos para a gliconeogênese devido a sua ação antilipolítica, controlando o fornecimento de ácidos graxos livres e glicerol a partir de tecidos periféricos para o fígado (COPPACK; JENSEN; MILES, 1994) e no músculo impede a degradação proteica reduzindo a liberação de aminoácidos gliconeogênicos (FREYSE et al., 1987). Além disso, a insulina inibe a secreção de glucagon (STEVENSON et al., 1987), proporcionando outro possível mecanismo indireto para a diminuição da produção de glicose hepática. Portanto, a insulina aumenta a captação de glicose via transportadores GLUT4 em músculo e tecido adiposo, estimula o acúmulo de glicogênio através do aumento do transporte de glicose no músculo e síntese de glicogênio no fígado, inibe a produção e liberação de glicose no fígado através do bloqueio da gliconeogênese e glicogenólise, reduz a lipólise e inibe a degradação proteica.

Quando há alterações funcionais na via de sinalização da insulina, desencadeando a diminuição do transporte e do metabolismo da glicose estimulado por esse hormônio em adipócitos, hepatócitos e células musculares esqueléticas, bem como o aumento da liberação da glicose hepática, ocorre o estado de resistência à insulina (KAHN; FLIER, 2000). Essa desordem metabólica ocasiona um processo crônico de hiperglicemia e hiperinsulinemia, os quais colaboram para o surgimento do DM2, da hipertensão e de doenças renais e cardiovasculares (BUSE, 2006; KOPELMAN, 2000).

A obesidade é considerada um dos principais fatores para o desenvolvimento da resistência à insulina e o DM2 (POLOZ; STAMBOLIC, 2015). A ração hiperlipídica demonstrou causar resistência à insulina no fígado (LIU et al., 2015), músculo (KEWALRAMANI et al., 2010) e tecido adiposo (LAVAU et al., 1979). É sugerido que a resistência à insulina seja 
causada pela exposição prolongada de células insulino dependentes a níveis elevados de ácidos graxos circulantes (POLOZ; STAMBOLIC, 2015), tais como o ácido palmítico e o ácido esteárico. Há várias hipóteses sobre com o excesso de ácidos graxos pode resultar em resistência à insulina, como: a relação inversa entre a disponibilidade de ácidos graxos e a utilização de glicose apresentada pelo ciclo de Randle; o acúmulo celular de derivados lipídicos (diacilglicerol e ceramidas); o estresse oxidativo; a modulação da expressão gênica; a inflamação; e a disfunção mitocondrial. Por outro lado, a expansão do tecido adiposo durante o desenvolvimento da obesidade leva há um aumento na secreção de citocinas próinflamatórias (TNF- $\alpha$ e IL-6) que causam prejuízos na via de sinalização da insulina (MARTINS, et al., 2012).

No músculo esquelético e no tecido adiposo a ligação da insulina ao seu receptor de membrana, bem como a fosforilação e a atividade cinase deste receptor, estão reduzidas em indivíduos com resistência à insulina (KAHN; FLIER, 2000). No tecido adiposo a fosforilação de IRS 1 está reduzida em indivíduos diabéticos e obesos com resistência à insulina (RONDINONE et al., 1997), bem como a atividade da PI3-K associada ao IRS 1 e 2 no músculo esquelético (KIM et al., 1999). Além disso, há uma diminuição da proteína GLUT 4 no músculo de ratos com diabetes induzida por estreptozotocina (RICHARDSON et al., 1991) e em adipócitos de indivíduos com DM2 (GARVEY et al., 1991).

É sugerido que o zinco esteja envolvido com a transdução de sinal do receptor de insulina auxiliando no controle glicêmico (HAASE; MARET, 2005; TANG; SHAY, 2001; YOSHIKAWA et al., 2004). Evidências demonstram que a suplementação com zinco possa melhorar a resistência à insulina em adipócitos através da via de sinalização desse hormônio, mostrando que esse mineral possui um efeito insulinomimético (BASUKI; HIROMURA; SAKURAI, 2007; NAITO; YOSHIKAWA; YASUI, 2011; NAKAYAMAet al., 2008; YOSHIKAWA et al., 2004) estimulando a atividade tirosina cinase do receptor de insulina, ativando a via da PI3-K e da AKT e consequentemente estimulando a translocação de vesículas que contêm GLUT4 dos seus sítios intracelulares para a membrana plasmática (TANG; SHAY, 2001).

O zinco mimetizou o efeito da insulina em adipócitos de ratos Wistar, diminuindo a liberação de ácidos graxos e atuando diretamente sobre os receptores de insulina e o PI3-K, aumentando a translocação de GLUT4 para a membrana (YOSHIKAWA et al., 2004) e induziu a fosforilação da GSK3- $\beta$ (NAITO; YOSHIKAWA; YASUI, 2011). Em adipócitos de ratos é possível que o zinco tenha um efeito estimulatório sobre a lipogênese similar à insulina e 
esse efeito é somado quando os dois são incubados juntos (COULSTON; DANDONA, 1980). Também em adipócitos de ratos, o tratamento com zinco mimetizou o efeito da insulina reduzindo a lipólise e melhorando o transporte de 3-O-metil-D-glicose (C7H14O6) (MAIO; CONTOREGGI, 1982). Em outras linhagens de célula, esse mineral ainda parece aumentar a fosforilação induzida por insulina da AKT em Células HUT-78 (linhagem celular de linfócito T) (JANSEN et al., 2012). Além disso, llouzet al. (2002) demonstraram que células humanas embrionárias de rim (HEK-293) tratadas com zinco apresentaram maior fosforilação da GSK3- $\beta$, permitindo a ativação da glicogênio sintase e a síntese de glicogênio, o que sugere um aumento na captação de glicose e uma ação semelhante à insulina. No entanto, há falta de informação a respeito dos efeitos do zinco sobre a via de sinalização da insulina no fígado e no músculo.

\subsection{Justificativa}

Embora os trabalhos supracitados relatem a participação do zinco na síntese e secreção da insulina, assim como sobre o controle da insulinemia e glicemia (ARQUILLA et al., 1978; BASUKI; HIROMURA; SAKURAI, 2007; ILOUZ et al., 2002; JANSEN et al., 2012; NAITO; YOSHIKAWA; YASUI, 2011; NYGAARD et al., 2014; OKAMOTO et al., 2011; QUARTERMAN; MILLS; HUMPHRIES, 1966; TANG; SHAY, 2001; YOSHIKAWA et al., 2004), não está claro se os aparentes benefícios da suplementação com esse mineral sobre o controle glicêmico de pacientes diabéticos poderiam estar associados a uma melhora nos mecanismos de secreção de insulina ou na sensibilidade dos tecidos responsivos à insulina. Dessa forma, novos estudos sobre o mecanismo de interação do zinco com a secreção de insulina, o controle glicêmico e sua ação antioxidante poderão fornecer bases para o entendimento bioquímico do possível papel desse mineral em prevenir a progressão para o DM2 e gerar novos conhecimentos acerca dos mecanismos envolvidos.

Nesse contexto, hipotetizamos que a suplementação com zinco deve prevenir, ao menos em parte, a progressão para o DM2 induzido por ração hiperlipídica por impedir a perda de sensibilidade da resposta secretória das células $\beta$ à glicose associada à ração e/ou por melhorar a sensibilidade dos tecidos periféricos à insulina. Ademais, é possível que parte desses efeitos putativos da suplementação com zinco se devam à sua ação antioxidante sobre as ilhotas pancreáticas. 


\section{OBJETIVOS}

O presente trabalho tem como proposta analisar o efeito do zinco no controle da secreção de insulina e no controle glicêmico, de modo a entender se a suplementação com o zinco previne ou retarda a manifestação do DM2 em modelo de camundongo em que a doença é induzida por ração hiperlipídica. 


\section{METODOLOGIA}

\subsection{Animais, tratamentos e acompanhamento}

O protocolo de experimentação animal foi submetido à apreciação prévia pela Comissão de Ética no Uso de Animais (CEUA) do Instituto de Ciências Biomédicas (ICB) da USP antes do início de qualquer experimento (Protocolo número 9, folha 15, livro 3), sendo utilizado como modelo experimental 120 camundongos, isogênicos, machos da linhagem C57BL/6, divididos em 6 lotes ao longo do estudo. Essa linhagem foi escolhida por ter as características metabólicas que favorecem o desenvolvimento da obesidade, resistência à insulina e DM2 a partir da ingestão de ração hiperlipídica (GALLOU-KABANI et al., 2007).

Os animais foram fornecidos pelo Biotério do Departamento de Anatomia (ICB 3 USP) e mantidos em número de 5 em gaiolas próprias para a criação de camundongos (Miniisoladores da linha Ventilife ${ }^{\circledR}$ - Alesco, Monte Mor, SP., Brasil), com saídas para ventilação e grade metálica inoxidável para a disposição da ração e do bebedouro. A liga metálica usada para a fabricação da grade e do bico do bebedouro era isenta de zinco na composição. 0 interior da gaiola era ambientado com maravalha autoclavada e enriquecimento ambiental no formato de iglu (Alesco, Monte Mor, SP., Brasil). As gaiolas eram higienizadas semanalmente e alocadas em estantes equipadas com ventilação mecânica (Alesco, Monte Mor, SP., Brasil) organizadas no biotério de criação específico para camundongos do Departamento de Fisiologia e Biofísica (ICB 1 - USP), sob condições ambientais controladas, temperatura de $22 \pm 2^{\circ} \mathrm{C}$, umidade relativa de $55 \pm 10 \%$ e ciclo de iluminação de 12 horas claro (6 às 18 horas) e 12 horas escuro (18 às 6 horas).

Após 11 dias do desmame, os camundongos foram identificados com traços que representavam a numeração de 1 a 5, feitos na parte proximal da cauda com pincel marcador permanente preto não tóxico (Sharpie, Oak Brook, IL., EUA). Após a identificação, os animais foram pesados através da Balança digital XP-1500 ${ }^{\circledR}$ (Denver instrument, Bohemia, NY., EUA) e tiveram a glicemia mensurada usando um glicosímetro FreeStyle Lite ${ }^{\circledR}$ (Abbott, Alameda, CA., EUA). Os animais foram divididos em 4 grupos experimentais, que receberam os seguintes tratamentos por 15 semanas:

- Grupo Controle Normal Fat Diet (NFD): os animais receberam água (pH 5.0) e ração normolipídica ad libitum; 
- Grupo Experimental Normal Fat Diet Zinc (NFDZ): os animais receberam ração normolipídica e água (pH 5.0) ad libitum suplementada com 20 mM de $\mathrm{ZnCl}_{2}$;

- Grupo Controle High Fat Diet (HFD): os animais receberam água (pH 5.0) e ração hiperlipídica ad libitum;

- Grupo Experimental High Fat Diet Zinc (HFDZ): os animais receberam ração hiperlipídica e água ( $\mathrm{pH}$ 5.0) ad libitum suplementada com $20 \mathrm{mM}$ de $\mathrm{ZnCl}_{2}$.

A ração foi elaborada segundo o American Institute of Nutrition (AIN) (REEVES; NIELSEN; FAHEY, 1993). A ração hiperlipídica ofertada foi acrescida de banha de porco em substituição ao amido de milho. A ração normolipídica era composta por $69,9 \%$ de carboidratos, $10 \%$ de gorduras e $20,1 \%$ de proteínas. Ao contrário, a ração hiperlipídica apresentava $60 \%$ do seu valor energético composto por gorduras, 19,9\% de carboidratos e 20,1\% de proteínas (Tabela 1 ).

$\mathrm{O} \mathrm{pH}$ da água foi ajustado com $\mathrm{HCl} 1 \mathrm{~N}$ para a diluição do $\mathrm{ZnCl}_{2}$. Para não haver diferenças entre o grupo experimental e o controle, exceto a ração e a suplementação, todos os grupos tiveram a água fornecida com o pH de 5.0, o que permitiu a completa diluição do $\mathrm{ZnCl}_{2}$.

Ao longo das 15 semanas de tratamento os animais eram semanalmente monitorados. Durante o acompanhamento a glicemia era mensurada por um glicosímetro FreeStyle Lite ${ }^{\circledR}$ (Abbott, Alameda, CA., EUA) entre 8 e 9 horas. A massa corporal, o resto e a reposição da ração foram pesados através da Balança digital XP-1500 ${ }^{\circledR}$ (Denver instrument, Bohemia, NY., EUA). O registro da ingestão de água foi feito através da quantificação do resto e da reposição de água através de proveta com capacidade para $500 \mathrm{~mL}$. Ambas, a ingestão de ração e água, foram determinadas pelo cálculo de resto-ingesta, uma relação entre o resto da ração e da água que sobrou no período de uma semana, subtraído pela quantidade de ração e da água oferecida, respectivamente. 
Tabela 1 - Composição e valor calórico das rações normolipídica e hiperlipídica, adaptado de Reeves, Nielsen e Fahey (1993).

\begin{tabular}{|c|c|c|c|c|}
\hline INGREDIENTES & NFD & KCAL & HFD & KCAL \\
\hline Caseína* $^{*}$ & $189,6 \mathrm{~g}$ & 606,6 & $258,4 \mathrm{~g}$ & 1034,7 \\
\hline L-Cistina* & $2,8 \mathrm{~g}$ & 9,0 & $3,8 \mathrm{~g}$ & 15,5 \\
\hline Amido de milho* & $413,1 \mathrm{~g}$ & 1321,8 & - & - \\
\hline Amido dextrinizado* & $161,5 \mathrm{~g}$ & 516,8 & $161,5 \mathrm{~g}$ & 646,0 \\
\hline Sacarose ${ }^{*}$ & $88,9 \mathrm{~g}$ & 284,5 & $88,9 \mathrm{~g}$ & 356,6 \\
\hline Celulose $^{*}$ & $54,6 \mathrm{~g}$ & - & $74,1 \mathrm{~g}$ & - \\
\hline Óleo de Soja* & $23,7 \mathrm{~mL}$ & 170,6 & $32,3 \mathrm{~mL}$ & 291,7 \\
\hline Banha* & $19,0 \mathrm{~g}$ & 136,4 & $316,6 \mathrm{~g}$ & 2849,4 \\
\hline Mix Mineral ${ }^{*}$ & $35,0 \mathrm{~g}$ & 29,4 & $47,95 \mathrm{~g}$ & 40,2 \\
\hline Boro & $0,5 \mathrm{mg}$ & - & $0,68 \mathrm{mg}$ & - \\
\hline Cálcio & $5,0 \mathrm{~g}$ & - & $6,8 \mathrm{~g}$ & - \\
\hline Cloro & $1,6 \mathrm{~g}$ & - & $2,1 \mathrm{~g}$ & - \\
\hline Cobre & $6,0 \mathrm{mg}$ & - & $8,2 \mathrm{mg}$ & - \\
\hline Cromo & $1,0 \mathrm{mg}$ & - & $1,3 \mathrm{mg}$ & - \\
\hline Enxofre & $0,3 \mathrm{~g}$ & - & $0,4 \mathrm{~g}$ & - \\
\hline Ferro & $35,0 \mathrm{mg}$ & - & $47,9 \mathrm{mg}$ & - \\
\hline Flúor & $1,0 \mathrm{mg}$ & - & $1,3 \mathrm{mg}$ & - \\
\hline Fósforo & $1,6 \mathrm{~g}$ & - & $2,1 \mathrm{~g}$ & - \\
\hline Iodo & $0,2 \mathrm{mg}$ & - & $0,28 \mathrm{mg}$ & - \\
\hline Lítio & $0,1 \mathrm{mg}$ & - & $0,13 \mathrm{mg}$ & - \\
\hline Magnésio & $0,5 \mathrm{~g}$ & - & $0,6 \mathrm{~g}$ & - \\
\hline Manganês & $10,5 \mathrm{mg}$ & - & $14,3 \mathrm{mg}$ & - \\
\hline Molibdênio & $0,2 \mathrm{mg}$ & - & $0,2 \mathrm{mg}$ & - \\
\hline Níquel & $0,5 \mathrm{mg}$ & - & $0,6 \mathrm{mg}$ & - \\
\hline Potássio & $3,6 \mathrm{~g}$ & - & $4,9 \mathrm{~g}$ & - \\
\hline Selênio & $0,1 \mathrm{mg}$ & - & $0,2 \mathrm{mg}$ & - \\
\hline Silício & $5,0 \mathrm{mg}$ & - & $6,8 \mathrm{mg}$ & - \\
\hline Sódio & $1,0 \mathrm{~g}$ & - & $1,4 \mathrm{~g}$ & - \\
\hline Vanádio & $0,1 \mathrm{mg}$ & - & $0,13 \mathrm{mg}$ & - \\
\hline Zinco & $30,1 \mathrm{mg}$ & - & $41,2 \mathrm{mg}$ & - \\
\hline Mix Vitamínico* & $10,0 \mathrm{~g}$ & - & $13,7 \mathrm{~g}$ & - \\
\hline Ácido fólico & $2,0 \mathrm{mg}$ & - & $2,7 \mathrm{mg}$ & - \\
\hline Ácido nicotínico & $30,0 \mathrm{mg}$ & - & $41,2 \mathrm{mg}$ & - \\
\hline Biotina & $0,2 \mathrm{mg}$ & - & $0,27 \mathrm{mg}$ & - \\
\hline Pantonato de cálcio & $16,0 \mathrm{mg}$ & - & $22 \mathrm{mg}$ & - \\
\hline Piridoxina. $\mathrm{HCl}$ & $7,0 \mathrm{mg}$ & - & $9,6 \mathrm{mg}$ & - \\
\hline Riboflavina & $6,0 \mathrm{mg}$ & - & $8,2 \mathrm{mg}$ & - \\
\hline Tiamina. $\mathrm{HCl}$ & $6,0 \mathrm{mg}$ & - & $8,2 \mathrm{mg}$ & - \\
\hline Vitamina A & $4000 \mathrm{UI}$ & - & $5500 \mathrm{UI}$ & - \\
\hline Vitamina B12 & $25,0 \mathrm{mcg}$ & - & $34,3 \mathrm{mcg}$ & - \\
\hline Vitamina D3 & $1000 \mathrm{UI}$ & - & 1375 UI & - \\
\hline Vitamina E & 75 UI & - & $103,1 \mathrm{UI}$ & - \\
\hline Vitamina K1 & $0,8 \mathrm{mg}$ & - & $1 \mathrm{mg}$ & - \\
\hline Bitartarato de Colina* & $1,9 \mathrm{~g}$ & - & $2,6 \mathrm{~g}$ & - \\
\hline Total & $1000 \mathrm{~g}$ & 3075 & $1000 \mathrm{~g}$ & 5231 \\
\hline
\end{tabular}

\footnotetext{
*Ingredientes usados para a elaboração da ração.
} 


\subsection{Teste intraperitoneal de tolerância à glicose}

Na décima quarta semana de tratamento, os animais foram submetidos ao teste intraperitoneal de tolerância à glicose (ipGTT). Após privação alimentar de 6 horas (7 às 13 horas) os animais tiveram a glicemia mensurada pelo glicosímetro FreeStyle Lite ${ }^{\circledR}$ (Abbott, Alameda, CA., EUA) através da coleta de amostras de sangue pela cauda, antes e após a administração intraperitoneal de soro ( $\mathrm{NaCl}$ 0,9\%) glicosado a 2\% (1 ml por 100 gramas de massa corporal) (Sigma-Aldrich, Saint Louis, MO., EUA), nos tempos 15, 30, 60, 90 e 120 minutos, sendo em seguida calculada a área sob a curva (AUC) (BOWE et al., 2004; VERAS et al., 2014).

\subsection{Teste de intraperitoneal tolerância à insulina}

Os animais também foram submetidos ao teste intraperitoneal de tolerância à insulina (iplTT) na décima quarta semana de tratamento com intervalo de 48 horas após o ipGTT. Após privação alimentar de 4 horas (7 às 11 horas) os animais tiveram a glicemia mensurada usando o mesmo glicosímetro, através da coleta de amostras de sangue pela cauda, antes e após a administração de insulina Humulin ${ }^{\circledR}$ (LILLY FRANCE, Fegersheim, Alsace, FRA) intraperitoneal (0,75 U/kg de massa corporal) nos tempos 5, 10, 15, 20, 30, 40 e 60 minutos(B ONORA et al., 1989; BONARA et al., 2000; BOWE et al., 2004; VERAS et al., 2014). A constante de decaimento de glicose (KITT) foi calculada entre os tempos 5 e 15 minutos a partir da regressão linear do logaritmo neperiano dos valores glicêmicos obtidos no teste (BONORA et al., 1989).

\subsection{Eutanásia e coleta de amostras}

Concluídas as 15 semanas de tratamento, os animais foram eutanasiados por deslocamento cervical seguido de decapitação, após privação alimentar de 8 horas (1 às 9 horas). O sangue torácico foi coletado e centrifugado a $425 \mathrm{~g}$, por 20 minutos, a $4^{\circ} \mathrm{C}$ para obtenção do soro que foi mantido a $-20^{\circ} \mathrm{C}$ para posteriores dosagens de glicose e insulina. Os músculos sóleos direito e esquerdo foram imediatamente removido para o estudo da sensibilidade dos tecidos periféricos à insulina em um lote de animais e para o estudo da captação e do metabolismo de glicose em outro lote. Uma amostra de fígado foi removida 
para o estudo da sensibilidade dos tecidos periféricos à insulina. E o pâncreas foi insuflado com solução de colagenase do tipo $\mathrm{V}$, isolado e digerido para a obtenção de ilhotas que serviram para o estudo da secreção estática de insulina.

\subsection{Avaliação dos parâmetros séricos}

As amostras de soro obtidas foram dosadas para avaliação da concentração de glicose $(\mathrm{mg} / \mathrm{dL})$ pelo método enzimático-calorimétrico de glicose oxidase Glicose Liquiform ${ }^{\circledR}$ (Labtest, Lagoa Santa, MG., Brasil) conforme a orientação do fabricante. A leitura fotométrica da absorbância das amostras e do padrão foi feita em espectrofotômetro SB 190 (CELM, São Caetano do Sul, SP., Brasil). A concentração de insulina $(\mu \mathrm{U} / \mathrm{mL}$ ) foi determinada por radioimunoensaio (ver 3.8) e por meio do ELISA Kit ${ }^{\circledast}$ (Rat/Mouse InsulinAssay EZRMI-13K, Millipore Corporation, Billerica, MA., EUA), de acordo com as especificações do fabricante. A determinação da concentração sérica de zinco $(\mathrm{ng} / \mathrm{mL})$ foi realizada por meio do método enzimático-calorimétrico pelo Zinc Assay $\mathrm{Kit}^{\circledR}$ (Sigma, Saint Louis, MO., EUA), também conforme a orientação do fabricante. A leitura fotométrica da absorbância das amostras e dos padrões, das análises de insulina e zinco, foram feitas no Synergy $\mathrm{H} 1^{\circledR}$ (Biotek, Winooski, VT., EUA).

A sensibilidade tecidual à ação da insulina e capacidade funcional das células $\beta$ pancreáticas em secretar insulina foram avaliadas pelo método HOMA (Homeostasis model assessment), um modelo matemático que prediz indiretamente a sensibilidade à insulina e a capacidade funcional das células $\beta$ pela medida da glicemia e insulinemia após privação alimentar. O resultado da glicemia e insulinemia após privação alimentar forneceram os índices de sensibilidade à insulina (HOMA-IR) e a capacidade secretória da célula $\beta$ (HOMA$\beta$ ) pelas seguintes equações: (a) HOMA-IR = Glicemia $x$ Insulina $\div 22,5$; e (b) $H O M A-\beta=20 x$ Insulina $\div$ (Glicemia - 3,5), respectivamente (MATTHEWS et al., 1985).

\subsection{Obtenção de ilhotas}

Após a eutanásia foi feita a laparotomia medial, a saída do ducto biliar comum para o duodeno foi ocluída e de 3 a $5 \mathrm{~mL}$ de solução de colagenase de Clostridium histolyticum, tipo V, (Sigma, Saint Louis, MO., EUA) em tampão Hanks ( $\mathrm{NaCl} 137$ mM, KCl 5 mM, CaCl 1 mM, 
$\mathrm{MgSO}_{4} 1 \mathrm{mM}, \mathrm{Na}_{2} \mathrm{HPO}_{4}$ 0,3 mM, $\mathrm{KH}_{2} \mathrm{PO}_{4}$ 0,4 mM, NaHCO $34 \mathrm{mM}, \mathrm{pH} 7.4$ equilibrado com carbogênio - mistura de $95 \%$ de $\mathrm{O}_{2}$ e $5 \%$ de $\mathrm{CO}_{2}$ ) foram injetados no ducto. Com este procedimento a solução flui através dos ductos pancreáticos, provocando a divulsão do tecido acinar. O pâncreas assim insuflado foi dissecado e posteriormente digerido a $37^{\circ} \mathrm{C}$ por 25 minutos. Em seguida, os tubos contendo o produto da digestão foram agitados manualmente, sendo completados com tampão Hanks e deixados no gelo por 7 minutos. Após esse período, o sobrenadante foi removido e completado com o mesmo tampão e deixados no gelo novamente. No total, esse procedimento de lavagem se repetiu por três vezes, para então, as ilhotas isoladas serem coletadas sob lupa estereoscópica.

\subsection{Secreção estática de insulina por ilhotas isoladas}

Grupos de 5 ilhotas foram pré-incubadas em tubos cônicos plásticos contendo $0,5 \mathrm{~mL}$ de tampão Krebs Henseleit ( $\mathrm{NaCl} 115$ mM; $\mathrm{CaCl}_{2} 1$ mM; $\mathrm{NaHCO}_{3} 24$ mM; KCl 5 mM; MgCl 2 $1 \mathrm{mM})$, pH 7.4 equilibrado com carbogênio $\left(95 \% \mathrm{O}_{2}\right.$ e $5 \%$ de $\left.\mathrm{CO}_{2}\right)$, suplementado com $0,2 \%$ de albumina sérica bovina (BSA) e 5,6 mM de glicose a $37{ }^{\circ} \mathrm{C}$ por 30 minutos. Após a préincubação estática, a solução de pré-incubação foi descartada e as ilhotas foram incubadas por 1 hora a $37^{\circ} \mathrm{C}$ com $0,5 \mathrm{~mL}$ do mesmo tampão, porém com diferentes concentrações de glicose (2,8 mM e 16,7 mM), sendo as secreções estáticas realizadas em triplicata para cada uma dessas condições experimentais. Ao final da incubação o sobrenadante foi transferido para tubos cônicos correspondentes e as ilhotas foram homogeneizadas na presença de 0,5 $\mathrm{mL}$ de solução álcool-ácido. Ambas as amostras foram então congeladas a $-20^{\circ} \mathrm{C}$ para posterior ensaio para insulina por meio de radioimunoensaio.

\subsection{Radioimunoensaio}

A insulinemia e a quantidade de insulina secretada foram determinadas por radioimunoensaio. Esse método é baseado na competição entre a insulina com radioisótopo ${ }^{125}$ I (insulina marcada com iodo - ${ }^{125}$ I) (Perkin Elmer, Waltham, MA., EUA) e uma quantidade desconhecida de insulina presente na amostra não-radioativa, baseando-se em uma reação do tipo antígeno-anticorpo. As duas formas de hormônios, radioativo e não-radioativo, competem por um mesmo número de locais de ligação ao anticorpo, quanto mais hormônio 
não-radioativo estiver presente, menos o hormônio radioativo irá se ligar. É mantida constante a quantidade de hormônio radioativo e do anticorpo, com isso a formação do complexo insulina marcada-anticorpo dependerá da quantidade de insulina não-radioativa presente na amostra. O complexo insulina-anticorpo pode ser facilmente precipitado pela absorção do hormônio ao polietilenoglicol (PM 6000) e dosado em contador tipo gama Wizard $1470^{\circledR}$ (Perkin Elmer, Turku, Finlândia), uma adaptação do método original que utiliza uma anti-gamaglobulina como cobaia produzida em coelho como precipitante (MORGAN; LAZAROW, 1963). Para a determinação da concentração de insulina em cada amostra, uma curva padrão foi preparada, na qual a relação insulina marcada ligada ao anticorpo e insulina marcada livre é expressa em função da insulina não-radioativa.

\subsection{Incubação do músculo sóleo com e sem insulina}

Os músculos sóleos, direito e esquerdo, dos animais foram rápida e cuidadosamente removidos após a eutanásia, pesados (8 a $10 \mathrm{mg}$ ), fixados em grampos de aço inoxidável mantendo a tensão de repouso e pré-incubados durante 30 minutos, a $35^{\circ} \mathrm{C}$, em tampão de bicarbonato Krebs-Ringer $\left(\mathrm{NaCl}\right.$ 118,5 mM, $\mathrm{NaHCO}_{3} 24 \mathrm{mM}, \mathrm{KCl} 3,6$ mM, MgSO $4.7 \mathrm{H}_{2} \mathrm{O}$ 0,5 $\mathrm{mM}, \mathrm{CaCl}_{2} .7 \mathrm{H}_{2} \mathrm{O}$ 1,5 mM), pré-gaseificado com carbogênio $\left(95 \% \mathrm{O}_{2}\right.$ e $5 \%$ de $\left.\mathrm{CO}_{2}\right)$ durante 30 segundos com escape de gases e 30 segundos sem escape de gases, contendo 5,6 mM de glicose, $1 \%$ de albumina de soro bovino (BSA), pH 7,4, em uma agitação a tensão de 0,2 g. Após esse período, os músculos foram transferidos para outros frascos contendo 200 ? do mesmo tampão, na presença ou não de $7 \mathrm{nmol} / \mathrm{l}$ de insulina. Desse modo, cada animal teve um músculo estimulado e outro não por insulina durante a incubação sob condições idênticas por 20 minutos em frascos tampados com atmosfera de $95 \%$ de $\mathrm{O}_{2}$ e $5 \%$ de $\mathrm{CO}_{2}$. Após o período de incubação, os músculos foram lavados brevemente em tampão de bicarbonato Krebs-Ringer a $4^{\circ} \mathrm{C}$, secos em papel filtro e congelados em nitrogênio líquido.

\subsection{Homogeneização do músculo sóleo e extração de proteínas}

Os músculos foram homogeneizados no macerador em tampão adequado para o mesmo (Tris 100 mM, EDTA $1 \mathrm{mM}$ ) suplementado com inibidores de fosfatase (Pirofosfato de $\mathrm{Na}^{+} 10 \mathrm{mM}$; Fluoreto de $\mathrm{Na}^{+} 100 \mathrm{mM}$ e Ortovanadato de $\mathrm{Na}^{+} 10 \mathrm{mM}$ ) e protease (PMSF 2 
mM e Protease Inhibitor Cocktail $^{\circledR}$ - Thermo Fisher, Chicago, IL., EUA). Após a homogeneização, foi adicionado Triton X-100 ao homogeneizado final na concentração de $1 \%$ e as amostras foram incubadas por 30 minutos a $4^{\circ} \mathrm{C}$. As amostras foram centrifugadas por 20 minutos, a $340 \mathrm{~g}$, para remoção do material insolúvel. O sobrenadante teve o seu conteúdo proteico determinado com o reagente de Bradford (BioRad, Hercules, CA., EUA), tratados com tampão de Laemmli acrescido de DTT $200 \mathrm{mM}$ na proporção de 5:1 (v/v). As amostras de proteína assim extraídas foram fervidas por 5 minutos em Banho-Maria e em seguida mantidas a $-80^{\circ} \mathrm{C}$ até posterior análise.

\subsection{Homogeneização do fígado e extração de proteínas}

A amostra do fígado removida foi colocada em um microtubo de $2 \mathrm{~mL}$ com um orifício na tampa e deixada em nitrogênio líquido até a momento da homogeneização, que foi feita com o auxílio do Polytron ${ }^{\circledR}$ (Kinematica AG, Lucerna, LU., SUI) em tampão próprio para esse tecido (Tris $100 \mathrm{mM}$, EDTA $1 \mathrm{mM}$, sacarose $250 \mathrm{mM}$ e pH 7,4). O tampão foi suplementado com inibidores de fosfatase (Pirofosfato de $\mathrm{Na}^{+} 10 \mathrm{mM}$; Fluoreto de $\mathrm{Na}^{+} 100$ mM e Ortovanadato de $\mathrm{Na}^{+} 10 \mathrm{mM}$ ) e protease (PMSF 2 mM e Protease Inhibitor Cocktail ${ }^{\circledR}$ Thermo Fisher, Chicago, IL., EUA). Durante a homogeneização o microtubo com a amostra se manteve imerso no gelo. O homogeneizado do fígado foi centrifugado por 40 minutos, a 290 g, para remoção do material insolúvel. O sobrenadante teve seu conteúdo proteico determinado com o reagente de Bradford (BioRad, Hercules, CA., EUA), tratado com tampão de Laemmli acrescido de DTT $200 \mathrm{mM}$ na proporção de 5:1 (v/v). As amostras de proteína assim extraídas foram fervidas por 5 minutos em Banho-Maria e em seguida mantidas a $80^{\circ} \mathrm{C}$ até posterior análise.

\subsection{Western blotting}

$30 \mu \mathrm{g}$ de proteínas totais de músculo e fígado foram submetidas à separação eletroforética em gel de poliacrilamida $12 \%$ contendo dodecilsulfato de sódio (SDS-PAGE 10\%) em aparelho para minigel Mini-Protean (BioRad, Hercules, CA., EUA). Após a eletroforese, as proteínas separadas no gel foram transferidas eletricamente para membranas de nitrocelulose por 1 hora a $15 \mathrm{~V}$ em aparelho Semi-dry (BioRad, Hercules, CA., 
EUA). Após a transferência, as membranas foram coradas com solução vermelho ponceau (0,1\% Ponceau S; 5\% ácido acético) e digitalizadas para posterior determinação da intensidade das bandas de proteínas, seguida da lavagem das membranas em água nanopura até a completa descoloração das mesmas.

A ligação inespecífica de anticorpos às membranas foi bloqueada pela incubação dessas com solução bloqueadora de gelatina 1\% ou Albumina Bovina Sérica (BSA) 5\% diluída em TBS (Tris $10 \mathrm{mM}$ e NaCl $1.5 \mathrm{mM}$ e pH 7,6) ao longo da noite a $4^{\circ} \mathrm{C}$, sob agitação, seguida de três lavagens com TBS-T (Tris 10 mM, NaCl 1.5 mM, Tween e pH 7,6). As membranas das amostras foram incubadas com os anticorpos contra as proteínas Akt (\#9272), p-AKT ser473 (\#5473), GSK3- $\beta$ (\#2710) e p-GSK3- $\beta$ ser9 (\#9336), fornecidos por Cell Signaling Technology (Danvers, MA., EUA). Os anticorpos foram diluídos (1:1000) em tampão TBS com 3\% de BSA conforme a orientação do fabricante. A incubação ocorreu por agitação durante 4 horas em temperatura ambiente ou ao longo da noite a $4^{\circ} \mathrm{C}$.

Após a incubação, as membranas foram incubadas por agitação com anticorpo secundário adequado conjugado com peroxidase (Millipore, Billerica, MA., EUA), durante 1 hora em temperatura ambiente e, em seguida, incubadas com solução contendo reagentes de quimiluminescência. As membranas foram então imediatamente expostas a filmes fotográficos e/ou reveladas em fotodocumentador Image Studio Digits $3.1^{\circledR}$ (LI-COR Biosciences, Lincoln, NE., EUA) onde também foi possível determinar a intensidade das bandas reveladas. A intensidade das bandas de autorradiografia reveladas foram determinadas por densitometria óptica usando o programa ImageJ 1.33u (Wayne Rasband, Bethesda, MD., EUA) e o Image Studio Digits $3.1^{\circledR}$ (LI-COR Biosciences, Lincoln, NE., EUA).

A determinação da expressão das proteínas foi normalizada por quantificação da membrana corada com a solução vermelho ponceau (RIVERO-GUTIÉRREZ et al., 2014; ROMERO-CALVO et al., 2010).

\subsection{Captação e metabolismo da glicose no músculo sóleo isolado}

Os músculos sóleos foram rápida e cuidadosamente isolados após a eutanásia, pesados (8 a $10 \mathrm{mg}$ ), fixados em grampos de aço inoxidável mantendo a tensão de repouso e pré-incubados durante 30 minutos, a $35^{\circ} \mathrm{C}$, em tampão de bicarbonato Krebs-Ringer $(\mathrm{NaCl}$ 118,5 mM, $\mathrm{NaHCO}_{3} 24 \mathrm{mM}, \mathrm{KCl} 3,6$ mM, $\mathrm{MgSO}_{4} .7 \mathrm{H}_{2} \mathrm{O}$ 0,5 mM, $\mathrm{CaCl}_{2} .7 \mathrm{H}_{2} \mathrm{O}$ 1,5 mM), pH 7,4, 
contendo 5,6 mM de glicose e 1\% de albumina de soro bovino (BSA), pré-gaseificado com mistura carbogênica $\left(95 \% \mathrm{O}_{2}\right.$ e $5 \%$ de $\left.\mathrm{CO}_{2}\right)$ durante 30 minutos antes do início do experimento. Ao iniciar a pré-incubação, com o músculo isolado já imerso no tampão, 1 minuto antes, o meio foi gaseificado com mistura carbogênica por 30 segundos com escape de gases e 30 segundos sem escape de gases. Os músculos foram então pré-incubados durante 30 minutos sob uma agitação e tensão de 0,2 g.

Após esse período, os músculos foram transferidos para outros frascos contendo 2 $\mathrm{mL}$ do mesmo tampão em que foram mantidas as mesmas condições da pré-incubação, porém agora na presença ou não de $7 \mathrm{nmol} / \mathrm{I}$ de insulina e acrecidos de $0,2 \mu \mathrm{Ci} / \mathrm{mL}$ de 2 deoxi-[2,6- $\left.{ }^{3} \mathrm{H}\right]-\mathrm{D}$-glicose, $0,3 \mu \mathrm{Ci} / \mathrm{mL}$ de $\left[\mathrm{U}-{ }^{14} \mathrm{C}\right]-\mathrm{D}$-glicose (Perkin Elmer, Waltham, MA., EUA) e um microtubo com $200 \mathrm{~mL}$ de $\mathrm{NaOH} 2 \mathrm{M}$. Os músculos foram incubados nessa condição por 1 hora. Ao final da incubação, os músculos foram lavados brevemente em tampão de bicarbonato Krebs-Ringer a $4^{\circ} \mathrm{C}$, secos em papel filtro e congelados em nitrogênio líquido.

Após congelamento dos músculos, o meio de incubação foi acidificado e mantido a $35^{\circ} \mathrm{C}$ e sob agitação constante por mais 1 hora. Então, os $200 \mathrm{~mL}$ da solução de $\mathrm{NaOH} 2 \mathrm{M}$ foi removida para a quantificação do ${ }^{14} \mathrm{CO}_{2}$ liberado pelo metabolismo muscular e incorporado nessa solução. Em seguida os tecidos congelados foram digeridos em solução de $\mathrm{KOH} 1 \mathrm{M}$, a $70^{\circ} \mathrm{C}$, por 20 minutos e $100 \mathrm{~mL}$ foi reservado para a quantificação da captação de 2-deoxi[2,6- $\left.{ }^{3} \mathrm{H}\right]-\mathrm{D}$-glicose, ao restante foi adicionada solução saturada de $\mathrm{Na}_{2} \mathrm{SO}_{4}$ e etanol absoluto e, em seguida, centrifugado a $4^{\circ} \mathrm{C}$ por 15 minutos a $425 \mathrm{~g}$. O sobrenadante foi desprezado e o pellet ressuspendido para então quantificar a síntese de glicogênio e a incorporação de [U${ }^{14} \mathrm{C}$ ]-D-glicose ao músculo (CHALLISS et al., 1986; CRETTAZ et al, 1980). A radiação foi quantificada em Tri-Carb ${ }^{\circledR}$ 2810TR (Perkin Elmer, Waltham, MA., EUA).

\subsection{Análise estatística}

Os dados obtidos foram inicialmente organizados em Excel $^{\circledR}$, sendo que os dados da massa corporal, glicemia e insulinemia de privação alimentar, HOMA-IR e $\beta$ e secreção estática de insulina foram testados quanto aos perfis das distribuições das médias e das variâncias, sendo os dados aberrantes excluídos quando eram maiores que o resultado da média mais o desvio padrão e menores que o resultado da média menos o desvio padrão. Os dados remanescentes foram então organizados no Graph Pad Prism $6^{\circledR}$ (Graph Pad Software, 
Inc., La Jolla, CA., EUA) sendo analisados por Two way ANOVA com pós-teste de Bonferroni com múltiplas comparações ou por teste $\mathrm{t}$ de Student. $P \leq 0,05$ foi considerado estatisticamente significativo. 


\section{RESULTADOS}

\subsection{Massa corporal e ingestão de ração, água e $\mathrm{ZnCl}_{2}$}

A Figura 1 mostra a evolução da massa corporal dos animais durante (Fig. 1, A) e no final do tratamento (Fig. 1, B). É possível observar que no final do tratamento os animais dos grupos HFD e HFDZ apresentaram maior ganho de massa corporal em relação aos animais dos grupos NFD e NFDZ $(P<0,001)$. No entanto, o mesmo não aconteceu com os grupos NFDZ e HFDZ em relação aos grupos NFD e HFD, respectivamente, sugerindo que apenas a ração hiperlipídica foi responsável pelo ganho de massa corporal e que não houve interferência da suplementação com o $\mathrm{ZnCl}_{2}$.

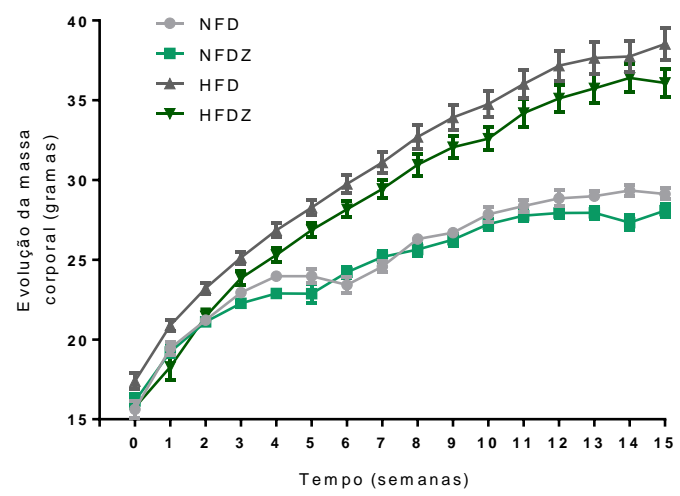

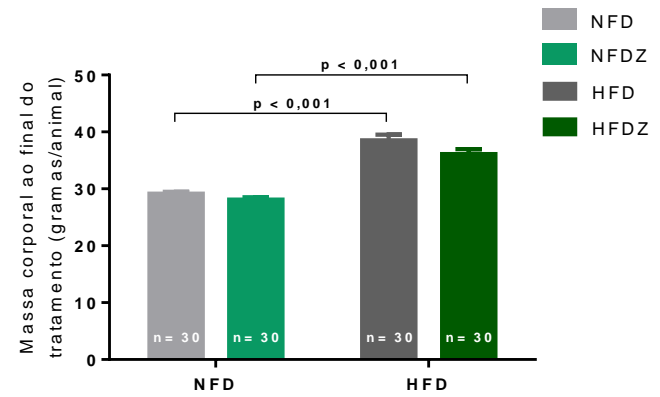

Figura 1. Massa corporal. Evolução da massa corporal (A) e massa corporal ao final do tratamento (B), dos animais dos grupos NFD e HFD controle e suplementados com $\mathrm{ZnCl}_{2}$. Os valores são médias \pm EPM e $n=30$ animais. Massa corporal ao final do tratamento: interação, $P>0,05$; ração, $P<0,001$ e zinco, $P>0,05$. Outras comparações irrelevantes não são mostradas. Analisado por Two way ANOVA com pós-teste de Bonferroni.

A análise da evolução da massa corporal também foi feita através da determinação da área sob a curva (AUC) conforme apresentado na Figura 2, sendo possível observar que a AUC do ganho de massa corporal ao longo de todo o tratamento (Fig. 2, A) foi maior no grupo HFD em relação ao grupo NFD e $\operatorname{NFDZ~}(P<0,05)$ e, no grupo HFDZ em relação ao grupo NFDZ $(P<0,05)$. Os grupos que receberam a suplementação com o $\mathrm{ZnCl}_{2}$ não apresentaram menor AUC em relação aos grupos que não receberam. 
A

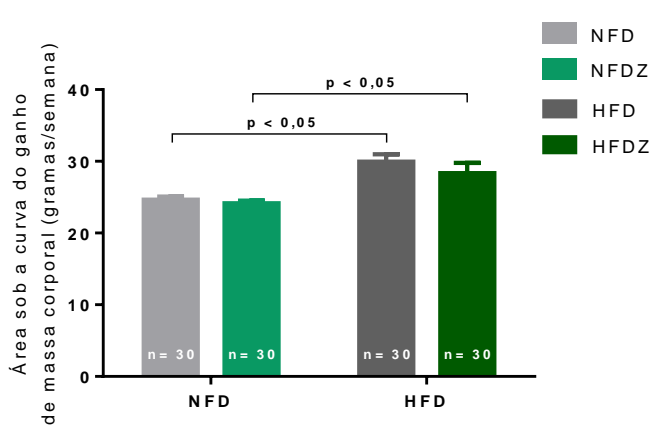

C

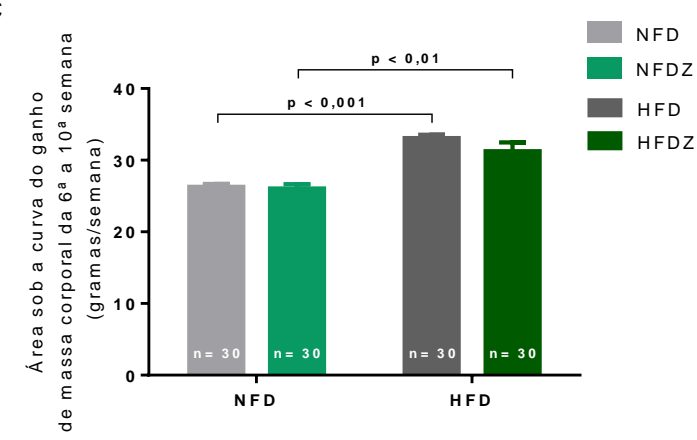

B

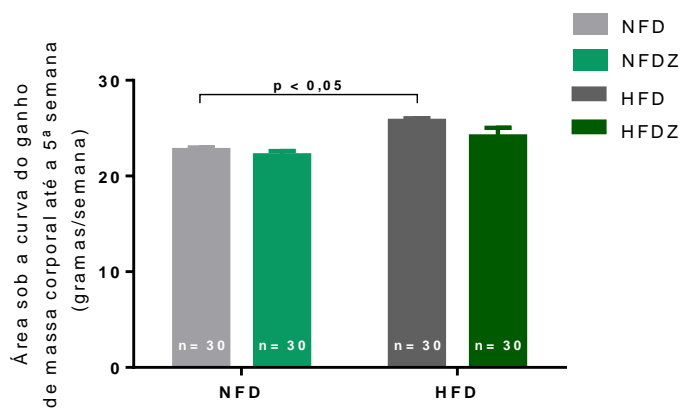

D

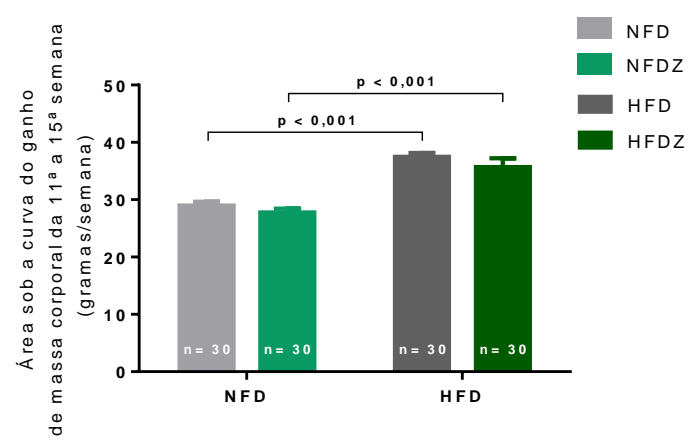

Figura 2. Área sob a curva (AUC) do ganho de massa corporal. Área sob a curva (AUC) do ganho de massa corporal total (A), AUC do ganho de massa corporal até a 5a semana (B), AUC do ganho de massa corporal da 6a a 10a semana (C) e AUC do ganho de massa corporal da 11 a a 15a semana (C), dos animais dos grupos NFD e HFD controle e suplementados com $\mathrm{ZnCl}_{2}$. Os valores são médias $\pm \mathrm{EPM}$ e $\mathrm{n}=30$ animais. AUC do ganho de massa corporal total: interação, $P>0,05$; ração, $P<0,001$ e zinco, $P>0,05$. AUC do ganho de massa corporal até a 5 a semana: interação, $P>0,05$; ração, $P<0,01$ e zinco $P>0,05$. AUC do ganho de massa corporal da 6 a a 10 a semana e da 11a a 15a semana: interação, $P>0,05$; ração, $P<0,001$ e zinco, $P>0,05$. Outras comparações irrelevantes não são mostradas. Analisado por Two way ANOVA com pós-teste de Bonferroni.

Nos primeiros cinco dias de tratamento (Fig. 2, B) é possível notar que o grupo HFD começa a apresentar uma maior AUC em relação aos grupos NFD e NFDZ $(P<0,05)$, no entanto, os animais do grupo HFDZ, alimentados com a mesma ração hiperlipídica, mas suplementados com o $\mathrm{ZnCl}_{2}$, ainda não apresentavam na mesma época essa diferença estatística quanto a massa corporal em relação aos animais alimentos com uma ração normolipídica. Entretanto, o aumento da AUC do grupo HFDZ torna-se estaticamente maior em relação aos grupos NFD e NFDZ $(P<0,01)$ e se manteve até o final do tratamento a partir da sexta semana, assim como no grupo HFD em relação ao grupo NFD e NFDZ $(P<0,001)$ (Fig. 2, C e D).

A ingestão das rações normolipídica e hiperlipídica nas quinze semanas de tratamento é apresentada na Figura 3. Ao analisá-la, é evidente observar a menor ingestão de ração hiperlipídica em relação à normolipídica ao longo do tratamento, o que é 
confirmado pela determinação da AUC da ingestão de ração (Fig. 3, B), que se apresentou estatisticamente menor entre os grupos HFD e HFDZ em relação aos grupos NFD e NFDZ, respectivamente, conforme apresentado por parte da analise estatística aplicada, confirmando assim a influência da composição da ração hiperlípidica sobre a menor ingestão da mesma nos grupos HFD e HFDZ.

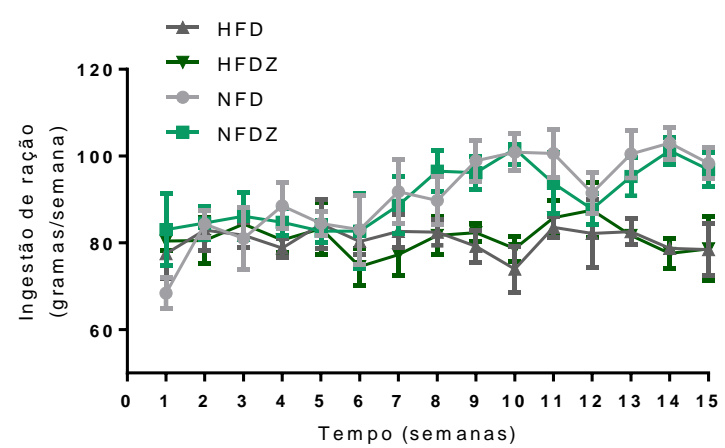

B

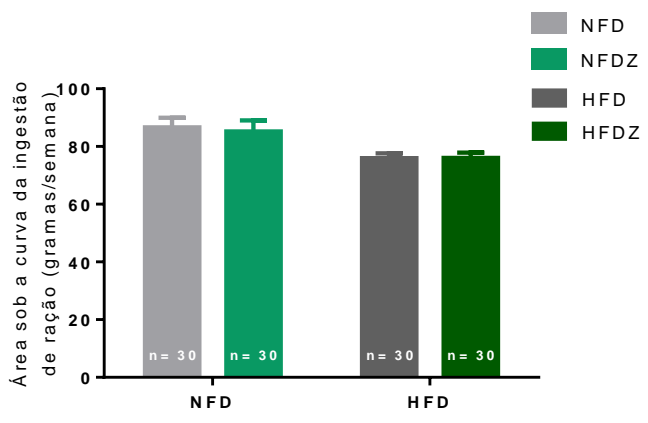

Figura 3. Ingestão de ração. Ingestão de ração ao longo do tratamento (A) área sob a curva (AUC) da ingestão de ração ao longo do tratamento (B), dos animais dos grupos NFD e HFD controle e suplementados $\operatorname{com~} \mathrm{ZnCl}_{2}$. Os valores são médias \pm EPM. AUC da ingestão de ração ao longo do tratamento: interação, $P>0,05 ;$ ração, $P<$ 0,05 e zinco, $P>0,05$. Analisado por Two way ANOVA com pós-teste de Bonferroni.

A Tabela 2 apresenta a massa corporal final dos animais após o tratamento com ração NFD e HFD, controle e suplementados com $\mathrm{ZnCl}_{2}$, sendo observado que os animais dos grupos HFD e HFDZ apresentaram maior massa corporal final e ingeriram menos ração que os animais do grupo NFD e NFDZ $(P<0,001)$, respectivamente. Do mesmo modo, foram avaliadas a ingestão hídrica $(\mathrm{mL})$ e a ingestão de $\mathrm{ZnCl}_{2}(\mathrm{mg})$ diária por animal, sendo observado que ao longo do tratamento os grupos NFDZ e HFDZ ingeriram menos água que os grupo NFD $(P<0,01)$ e HFD $(P<0,05)$, respectivamente. É possível que o $\mathrm{ZnCl}_{2}$ dissolvido na água tenha prejudicado a sua palatabilidade devido à menor ingestão hídrica diária nos grupos suplementados, já que a composição e o pH da água em ambos os grupos, controle e experimental, eram iguais, sendo acrescentando apenas o $\mathrm{ZnCl}_{2}$ na água dos grupos NFDZ e HFDZ. No entanto, entre os respectivos grupos não houve diferença estatística da ingestão do $\mathrm{ZnCl}_{2}$ suplementado e a ingestão diário de zinco por animal presente na composição das rações foi muito pequena se comparada ao valor suplementado, apesar de ter se apresentado maior nos grupos HFD e HFDZ em relação aos grupos NFD e NFDZ $(P<0,05)$, respectivamente, devido a maior quantidade de minerais apresentes na ração hiperlipídica (Tabela 1). 
Tabela 2 - Massa corporal, ingestão de ração, ingestão hídrica, ingestão de zinco presente na ração, suplementação com $\mathrm{ZnCl}_{2}$ e ingestão calórica dos animais dos grupos NFD e HFD controle e suplementados com $\mathrm{ZnCl}_{2}$.

\begin{tabular}{|c|c|c|c|c|}
\hline Parâmetro & NFD & NFDZ & HFD & HFDZ \\
\hline Massa corporal final (g) & $29,1 \pm 0,3$ & $28,0 \pm 0,4$ & $38,5 \pm 1,0 \S \S \S$ & $36,0 \pm 0,8^{\square \square \square}$ \\
\hline Ingestão diário de ração por animal (g/dia) & $2,6 \pm 0,1$ & $2,5 \pm 0,1$ & $2,3 \pm 0,0$ & $2,3 \pm 0,0$ \\
\hline $\begin{array}{l}\text { Ingestão calórica diária por animal } \\
\text { (Kcal/dia) }\end{array}$ & $9,9 \pm 0,4$ & $9,8 \pm 0,4$ & $12,0 \pm 0,2^{\S}$ & $12,1 \pm 0,3^{\square}$ \\
\hline $\begin{array}{l}\text { Ingestão diária de zinco presente na ração } \\
\text { por animal (mg/dia) }\end{array}$ & $0,06 \pm 0,0$ & $0,06 \pm 0,0$ & $0,09 \pm 0,0^{\S \S \S}$ & $0,09 \pm 0,0^{\square \square \square}$ \\
\hline Ingestão hídrica diária por animal (mL/dia) & $3,9 \pm 0,1$ & $3,0 \pm 0,1^{\Delta \Delta}$ & $3,6 \pm 0,1$ & $2,9 \pm 0,0^{*}$ \\
\hline $\begin{array}{l}\text { Ingestão diária de } \mathrm{ZnCl}_{2} \text { por animal } \\
\text { (mg/dia) }\end{array}$ & - & $8,3 \pm 0,3$ & - & $8,0 \pm 0,2$ \\
\hline $\begin{array}{l}\text { Ingestão de } \mathrm{ZnCl}_{2} \text { por massa corporal } \\
\text { (mg/g/dia) }\end{array}$ & - & $0,33 \pm 0,0$ & - & $0,28 \pm 0,0^{\square}$ \\
\hline \multicolumn{5}{|c|}{$\begin{array}{l}\text { Valores são médias } \pm \text { EPM e } \mathrm{n}=30 \text { animais. Massa corporal final: interação, } P>0,05 ; \text { ração, } P<0,001 \text { e } \\
\text { zinco, } P>0,05 \text {. Ingestão diário de ração: interação, } P>0,05 ; \text { ração, } P<0,05 \text { e zinco, } P>0,05 \text {. Ingestão } \\
\text { calórica diária por animal: interação, } P>0,05 ; \text { ração, } P<0,001 \text { e zinco, } P>0,05 \text {. Ingestão diária de zinco } \\
\text { presente na ração: interação, } P>0,05 ; \text { ração, } P<0,001 \text { e zinco, } P>0,05 \text {. Ingestão hídrica diária: interação, } P \\
>0,05 ; \text { ração, } P>0,05 \text { e zinco, } P<0,001 \text {. } \S \S \S P<0,001 \text { vs NFD; } \S P<0,05 \text { vs NFD; } \square \square \square P<0,001 \text { vs NFDZ; } \square \\
P<0,05 \text { vs NFDZ; }{ }^{*} P<0,05 \text { vs HFD; } \Delta \Delta P<0,001 \text { vs NFD. Outras comparações irrelevantes não são } \\
\text { mostradas. Analisado por Two way ANOVA com pós-teste de Bonferroni. A ingestão diária de } \mathrm{ZnCl}_{2} \text { e a } \\
\text { ingestão de } \mathrm{ZnCl}_{2} \text { por massa corporal foram analisadas por teste t de Student. }\end{array}$} \\
\hline
\end{tabular}

A ingestão de $\mathrm{ZnCl}_{2}(\mathrm{mg})$ por grama de massa corporal foi menor entre os animais do grupo HFDZ em relação ao grupo NFDZ $(P<0,05)$, isso devido a maior massa corporal dos animais do grupo HFDZ. E quanto à ingestão calórica, essa foi maior entre os animais dos grupos HFD e HFDZ em relação aos animais dos grupos NFD e NFDZ $(P<0,05)$, respectivamente.

\subsection{Glicemia e insulinemia}

Os valores dos níveis de glicemia basal dos animais, mensurados antes e durante o tratamento e a determinação da AUC dos valores de glicemia são apresentados a seguir na Figura 4. A determinação da AUC para os valores de glicemia mensurados durante todo o tratamento mostra que os animais dos grupos HFD e HFDZ, apresentaram maior AUC em relação aos animais dos grupos NFD e NFDZ $(P<0,001)$, respectivamente, e que o resultado da AUC do grupo HFDZ mostrou-se menor em relação ao grupo HFD $(P<0,001)$, indicando uma possível relação entre suplementação com o $\mathrm{ZnCl}_{2}$ e a diminuição da glicemia, apesar desse efeito não ter sido observado na determinação da AUC da glicemia do grupo NFDZ em relação ao grupo NFD (Fig. 4, B). 
A

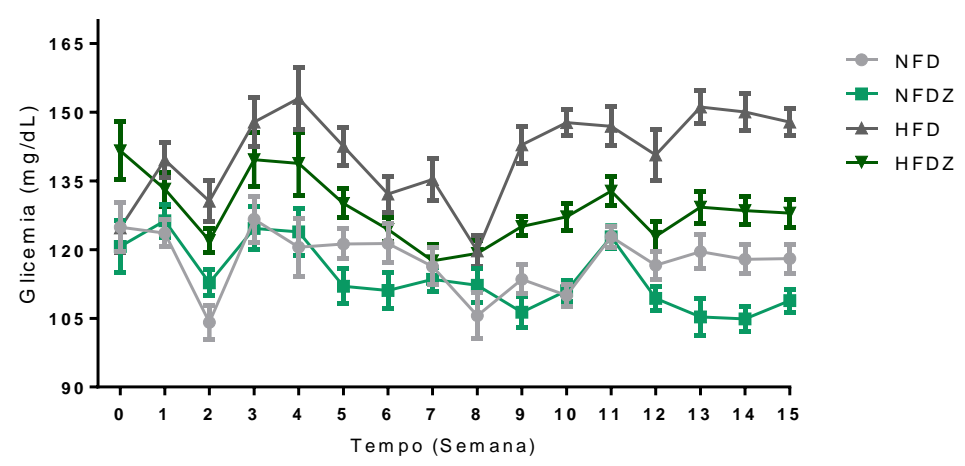

B

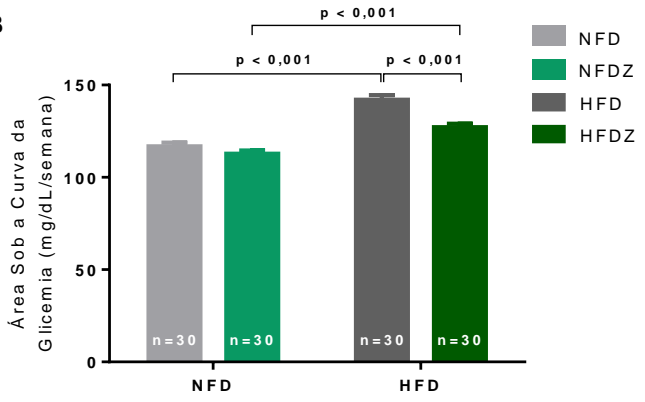

D

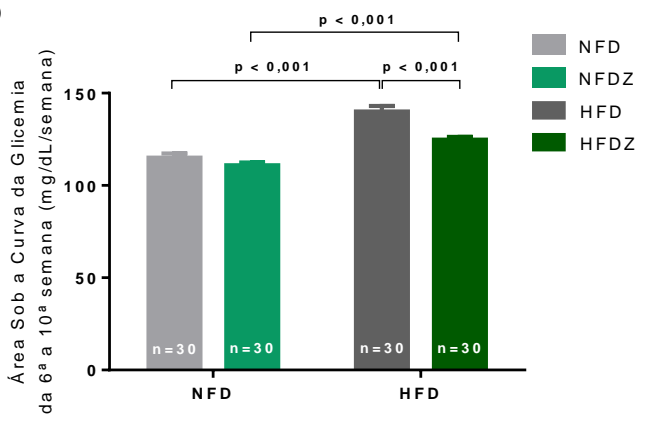

C

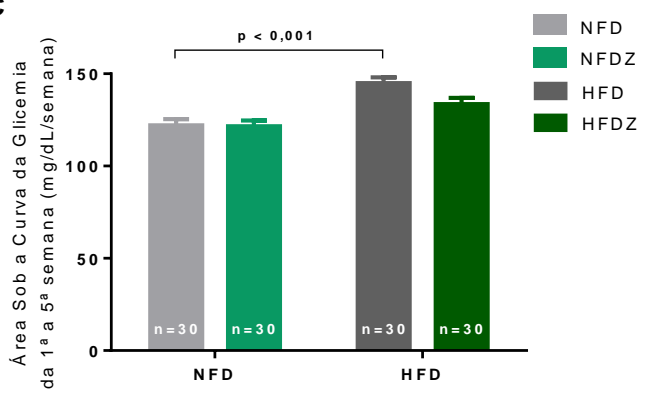

E

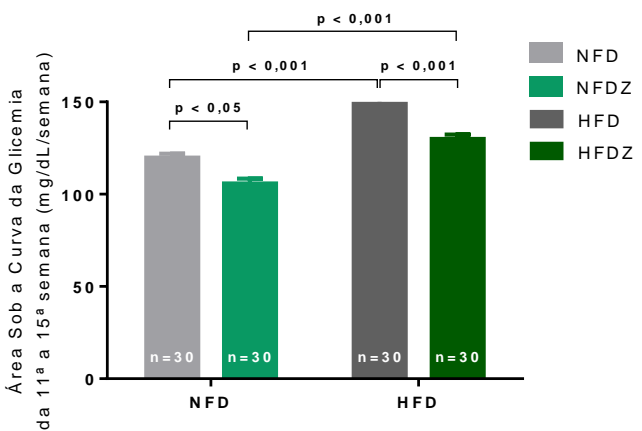

Figura 4. Evolução da glicemia dos animais medida entre 8 e 9 horas durante as $\mathbf{1 5}$ semanas de tratamento. Registro semanal dos valores de glicemia dos animais $(A)$, área sob a curva (AUC) da glicemia ao longo do tratamento (B), AUC da glicemia 1a a 5a semana (C), AUC da glicemia 6a a 10a semana (D) e AUC da glicemia 11a a 15a semana (E), dos grupos NFD e HFD controle e suplementados com $\mathrm{ZnCl}_{2}$. Valores são médias $\pm \mathrm{EPM}$ e $\mathrm{n}=$ 30 animais. AUC da glicemia ao longo do tratamento: interação, $P<0,05$, ração e zinco $P<0,001$. AUC da glicemia $1^{\text {a }}$ a $5^{\text {a }}$ semana: interação, $P<0,05$, ração, $P<0,001$ e zinco $P>0,05$.AUC da 6a a 10a semana: interação, $P<0,05$; ração e zinco $P<0,001$; AUC da 11a a 15a semana: interação, $P<0,05$; ração e zinco $P<$ 0,001 . Outras comparações irrelevantes não são mostradas. Analisado por Two way ANOVA com pós-teste de Bonferroni.

Analisando a AUC da glicemia em períodos separados, é possível observar que a determinação da AUC até a quinta semana de tratamento (Fig. 4, C) está maior entre os grupos HFD e HFDZ em relação aos grupos NFD $(P<0,001)$ e NFDZ $(P<0,05)$, respectivamente, sugerindo maior glicemia devido à ingestão de ração hiperlipídica nesse período. No entanto, nesses primeiros dias de tratamento a suplementação com o $\mathrm{ZnCl}_{2}$ não 
apresentou efeito favorável sobre o controle glicêmico. Por outro lado, a partir da sexta semana de tratamento (Fig. 4, D) a AUC dos grupos HFD $(P<0,001)$ e HFDZ $(P<0,001)$ mantiveram-se maiores em relação aos grupos NFD e NFDZ, respectivamente. Nota-se agora uma diminuição significativa da AUC do grupo HFDZ quando o mesmo é comparado ao grupo HFD $(P<0,001)$, sugerindo que a suplementação com o $\mathrm{ZnCl}_{2}$, a única variável entre esses grupos, pode ser a responsável pela diminuição da glicemia. Apenas nas últimas semanas de tratamento (Fig. 4, E) que a AUC do grupo NFDZ $(P<0,05)$ esteve menor em relação ao grupo NFD, sugerindo um efeito mais tardio da suplementação com o $\mathrm{ZnCl}_{2}$ nos animais eutróficos alimentados com ração normolipídica.

A Figura 5 apresenta o resultado da glicemia (Fig. 5, A) e insulinemia (Fig. 5, B) após oito horas de privação alimentar. Confirmando os resultados de glicemia mensurados durante todo o tratamento, ao final das quinze semanas de tratamento, o grupo HFD apresentou maior glicemia após privação alimentar em relação aos grupos NFD, NFDZ e HFDZ $(P<0,05)$, mas não foi encontrada diferença estatística entre o grupo NFDZ e NFD. Por outro lado, apesar de haver uma menor glicemia plasmática entre os animais do grupo HFDZ em relação ao grupo HFD $(P<0,05)$, a insulinemia entre esses grupos, não apresentou diferença estatística quando analisada, mas a suplementação com o $\mathrm{ZnCl}_{2}$ foi responsável pela maior média de insulinemia no grupo $\operatorname{HFDZ}(19,1 \pm 1,0)$ em relação ao grupo $\operatorname{HFD}(17,8$ $\pm 0,8$ ) (Tabela 3). Entretanto, a insulinemia do grupo HFDZ se apresentou significativamente maior em relação ao grupo NFD $(P<0,05)$, mas esse aumento não foi relacionado ao zinco e sim à ração conforme a análise estatística.

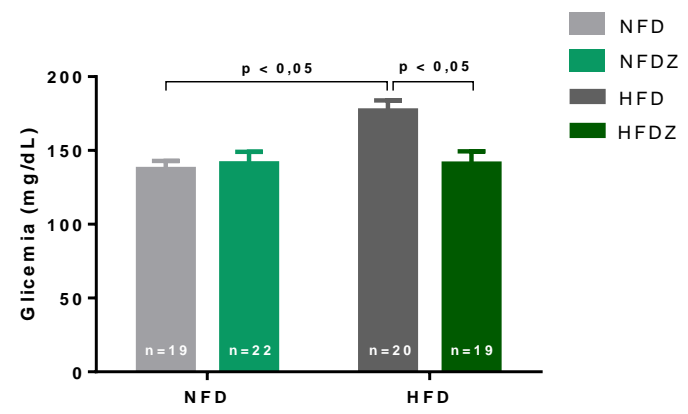

B

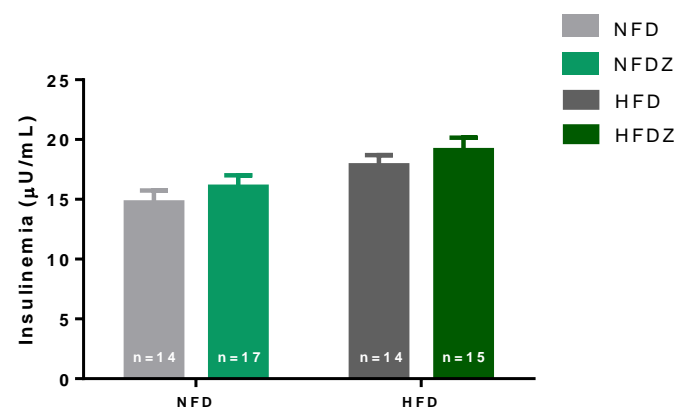

Figura 5. Glicemia e insulinemia após privação alimentar de $\mathbf{8}$ horas ao final do tratamento. Glicemia (A) e insulinemia (B) após privação alimentar dos animais dos grupos NFD e HFD controle e suplementados com $\mathrm{ZnCl}_{2}$. A coleta de sangue foi feita às 9 horas. Valores são médias \pm EPM. Glicemia: interação, $P<0,05 ;$ ração, $P$ $<0,05$ e zinco, $P<0,05$. Insulinemia: interação, $P>0,05$; ração, $P<0,05$ e zinco, $P>0,05$. Outras comparações irrelevantes não são mostradas. Analisado por Two way ANOVA com pós-teste de Bonferroni. 


\subsection{HOMA}

Os índices HOMA-IR e HOMA- $\beta$ dos animais avaliados são apresentados na Figura 6. Entre os grupos estudados apenas os animais dos grupos HFD mostraram-se mais resistentes à insulina em relação aos grupos NFD e NFDZ $(P<0,05)$, mostrando que possivelmente apenas a composição da ração favoreceu o surgimento da resistência e que a suplementação com $\mathrm{ZnCl}_{2}$ não foi capaz de afetar a resistência induzida pela ração (Fig. 6, A). Por outro lado, no HOMA- $\beta$, apesar de não haver diferença estatística entre os grupos pelo pós-teste de Bonferoni, a análise estatística por Two way ANOVA sugere que a suplementação com o $\mathrm{ZnCl}_{2}$ melhorou a capacidade funcional das células $\beta(P<0,05)$ (Fig. 6, B).

A

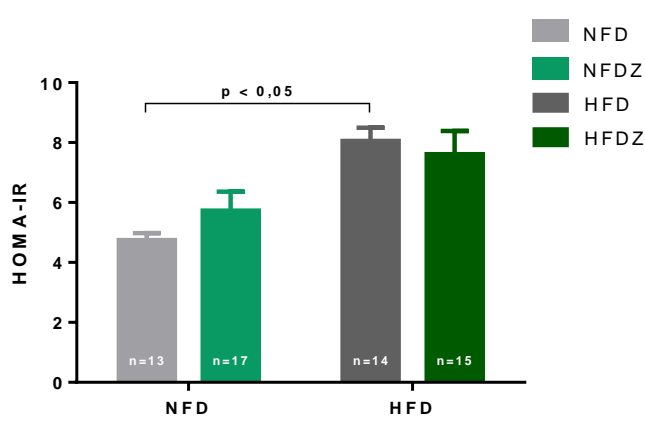

B

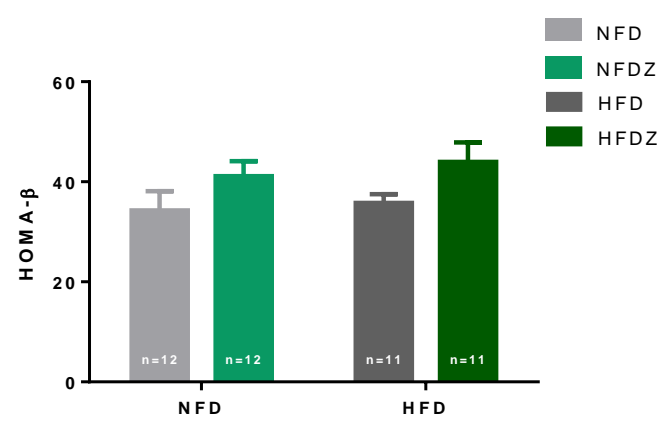

Figura 6. Homeostasis Model Assessment (HOMA) ao final do tratamento. Índice de insulina-resistência (HOMA-IR) (A) e o índice de funcionamento da célula $\beta$ (HOMA- $\beta$ ) (B) dos animais dos grupos NFD e HFD controle e suplementados com $\mathrm{ZnCl}_{2}$. HOMA-IR: interação, $P>0,05$; ração, $P<0,001$ e zinco, $P>0,05$. HOMA$\beta$ : interação, $P>0,05$; ração, $P>0,05$ e zinco $P<0,05$. Valores são médias \pm EPM. Outras comparações irrelevantes não são mostradas. Analisado por Two way ANOVA com pós-teste de Bonferroni.

\subsection{Teste intraperitoneal de tolerância à glicose}

A Figura 7 apresentas alterações dos níveis glicêmicos dos grupos avaliados durante o teste intraperitoneal de tolerância à glicose (ipGTT) (Fig. 7, A) e a área sob a curva (AUC) calculada a partir do ipGTT (Fig. 7, B). A AUC foi maior no grupo HFD em relação aos grupos NFD e NFDZ $(P<0,001)$, e os grupos suplementados com $\mathrm{ZnCl}_{2}, \mathrm{NFDZ}$ e HFDZ apresentaram uma AUC menor que os grupos controle, NFD $(P<0,05)$ e HFD $(P<0,001)$, respectivamente. Sugerindo que a ração hiperlipídica e a suplementação com $\mathrm{ZnCl}_{2}$ foram responsáveis pelo aumento e diminuição da AUC de glicemia, respectivamente. 
A

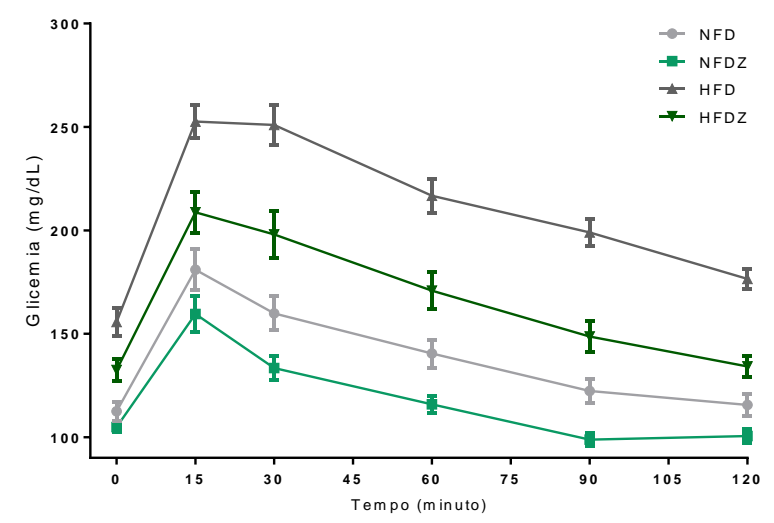

B

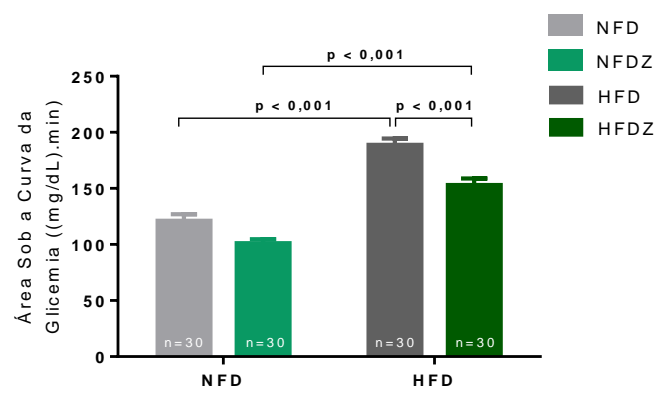

Figura 7. Teste intraperitoneal de tolerância à glicose (ipGTT). Alterações da glicemia durante o teste intraperitoneal de tolerância à glicose (ipGTT) (A) e área sob a curva (AUC) do teste aplicado calculado a partir dos valores brutos de glicemia, e não em relação à concentração no tempo 0 minuto (B) dos animais dos grupos NFD e HFD controle e suplementados com $\mathrm{ZnCl}_{2}$. Valores são médias \pm EPM. Interação, $P>0,05 ;$ ração, $P<0,001$ e zinco $P<0,001$. Outras comparações irrelevantes não são mostradas. Analisado por Two way ANOVA com pós-teste de Bonferroni.

\subsection{Teste intraperitoneal de tolerância à insulina}

As alterações dos níveis de glicemia durante o teste intraperitoneal de tolerância à insulina (iplTT) e a constante de decaimento de glicose (KITT \% $\mathrm{min}^{-1}$ ) dos grupos estudos são mostrados na Figura 8. A oferta da ração hiperlipídica foi responsável pelo surgimento da ressitência à insulina nos grupos HFD e HFDZ, mas a suplementação paralela com o $\mathrm{ZnCl}_{2}$ não impediu a instalação da resistência a esse hormônio entre os animanis do grupo HFDZ.

A

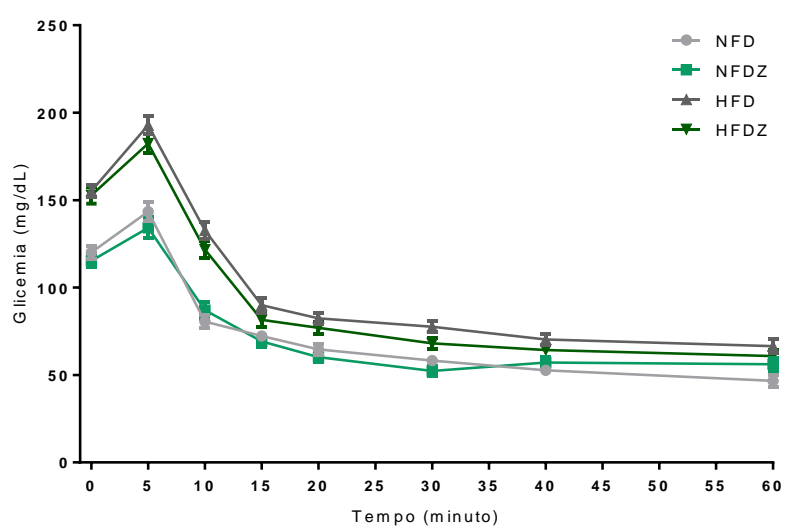

B

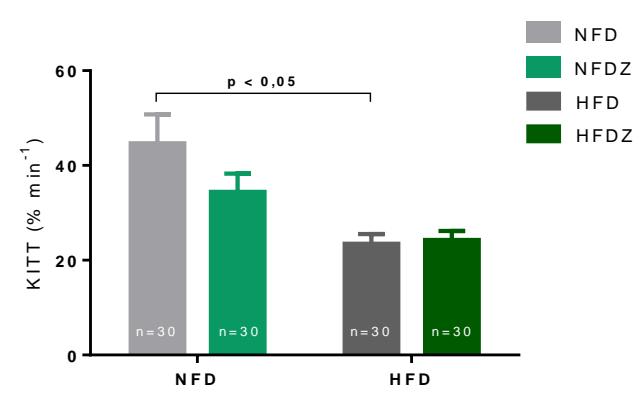

Figura 8. Teste intraperitoneal de tolerância à insulina (ipITT). Alterações dos níveis de glicemia durante o Teste intraperitoneal de tolerância à insulina (ipITT) (A) e Constante de decaimento da glicemia (KITT) durante o ipITT entre 5 e 15 minutos (B) dos animais dos grupos NFD e HFD controle e suplementados com $\mathrm{ZnCl}_{2}$. Interação, $P>0,05$; ração, $P<0,001$ e zinco, $P>0,05$. Valores são médias \pm EPM. Ração, $P<0,05$. Outras comparações irrelevantes não são mostradas. Analisado por Two way ANOVA com pós-teste de Bonferroni. 
O grupo HFD apresentou maior glicemia ao longo do teste se comparado ao grupo NFD $(P<0,05)$, antes e após a administração de insulina (Fig. 8, A). Além disso, a constante de decaimento de glicose (Fig. 8, B) mostra que o grupo HFD estava mais resistente à insulina que o grupo NFD $(P<0,05)$, sugerindo que apenas a composição da ração teve efeito sobre esse resultado.

Conforme apresentado nas figuras anteriores, a Tabela $\mathbf{3}$ apresenta a seguir os valores médios de alguns dos parâmetros já abordados e as concentrações de zinco sérico, que conforme a suplementação de $\mathrm{ZnCl}_{2}$, se mostrou maior entre os grupos NFDZ e HFDZ, em relação aos grupos NFD e HFD $(P<0,05)$, respectivamente.

Tabela 3 - Glicemia, insulinemia e zincemia após privação alimentar, índices HOMA-IR e $\beta$, constante de decaimento de glicose no ipITT e área sob a curva da glicemia no ipGTT dos animais dos grupos NFD e HFD controle e suplementados com $\mathrm{ZnCl}_{2}$.

\begin{tabular}{lcccc}
\hline \multicolumn{1}{c}{ Parâmetro } & NFD & NFDZ & HFD & HFDZ \\
\hline Glicemia $(\mathrm{mg} / \mathrm{dL})$ & $137,4 \pm 5,4$ & $141,1 \pm 7,9$ & $177,7 \pm 6,8^{\S \S \S}$ & $141,0 \pm 8,3^{*}$ \\
Insulinemia $(\mu \mathrm{U} / \mathrm{dL})$ & $14,7 \pm 1,0$ & $16,0 \pm 0,9$ & $17,8 \pm 0,8$ & $19,1 \pm 1,0$ \\
Zincemia $(\mathrm{ng} / \mu \mathrm{L})(\mathrm{n}=5)$ & $1,38 \pm 0,0$ & $2,82 \pm 0,1^{\Delta}$ & $1,56 \pm 0,2$ & $2,82 \pm 0,4^{*}$ \\
HOMA-IR & $4,7 \pm 0,2$ & $5,7 \pm 0,6$ & $8,0 \pm 0,4^{\S}$ & $7,6 \pm 0,7$ \\
HOMA- $\beta$ & $34,2 \pm 3,8$ & $41,0 \pm 3,0$ & $35,7 \pm 1,7$ & $43,9 \pm 3,8$ \\
Constate de decaimento da glicemia & $44,6 \pm 6,1$ & $34,4 \pm 3,8$ & $23,4 \pm 2,0^{\S}$ & $24,2 \pm 1,8$ \\
(KITT \% min ${ }^{-1}$ ) & & & $188,8 \pm$ & $153,1 \pm 5,8^{* * *}$ \\
AUC da glicemia do ipGTT & $121,4 \pm 5,7$ & $101,2 \pm 3,5$ & $5,6^{\S \S \S}$ & \\
((mg/dL).min) & & & & \\
\hline
\end{tabular}

Valores são médias \pm EPM e $\mathrm{n}=11$ a 30 animais. Glicemia: interação, $P<0,05$; ração, $P<0,05$ e zinco, $P<$ 0,05 . Insulinemia: interação, $P>0,05$; ração, $P<0,05$ e zinco, $P>0,05$. Zincemia: interação, $P>0,05$; ração, $P>0,05$ e zinco, $P<0,01$. HOMA-IR: interação, $P>0,05$; ração, $P<0,001$ e zinco, $P>0,05$. HOMA- $\beta$ : interação, $P>0,05$; ração, $P>0,05$ e zinco $P<0,05$. KITT: Interação, $P>0,05$; ração, $P<0,001$ e zinco, $P>$ 0,05. AUC da glicemia do ipGTT: interação, $P>0,05$; ração, $P<0,001$ e zinco $P<0,001$. $\S \S \S P<0,001$ vs NFD; $\S \S P<0,001$ vs NFD; ${ }^{* *} P<0,001$ vs HFD; ${ }^{*} P<0,05$ vs HFD; $\Delta P<0,05$ vs NFD. Outras comparações irrelevantes não são mostradas. Analisado por Two way ANOVA com pós-teste de Bonferroni.

\subsection{Secreção estática de insulina}

Os resultados dos ensaios de secreção estática de insulina em 2,8 e 16,7 mM de glicose são apresentados na Figura 9. Na análise da secreção de insulina por ilhotas foi observado que as ilhotas dos grupos NFD, NFDZ e HFDZ incubadas com 16,7 mM de glicose apresentaram como esperado aumento significativo na secreção se comparadas com as ilhotas dos mesmos grupos quando incubadas com $2,8 \mathrm{mM}$ de glicose $(P<0,05)$. No entanto, 
o grupo HFD quando incubado com 16,7 mM de glicose não apresentou aumento estatístico em relação às ilhotas do mesmo grupo incubadas com 2,8 mM de glicose (Fig. 9, A). Contudo, ao analisar o percentual de secreção de insulina em relação ao conteúdo (Fig. 4, C) observa-se que apenas os grupos NFD e NFDZ apresentaram aumento significativo na secreção das ilhotas incubadas em 16,7 mM de glicose em relação as que foram incubadas em $2,8 \mathrm{mM}(P<0,05)$. Além disso, as ilhotas do grupo NFDZ e HFDZ não apresentaram aumento significativo na secreção e no percentual de secreção de insulina em relação às ilhotas do grupo NFD e HFD, respectivamente. Apesar de não haver diferença estatística, a média da secreção de insulina e do percentual de secreção de insulina por ilhota em 16,7 mM de glicose se encontra maior no grupo HFDZ em relação ao grupo HFD. O conteúdo de insulina por ilhota (Fig. 4, B) não apresentou diferença estatística entre os grupos estudados.

A

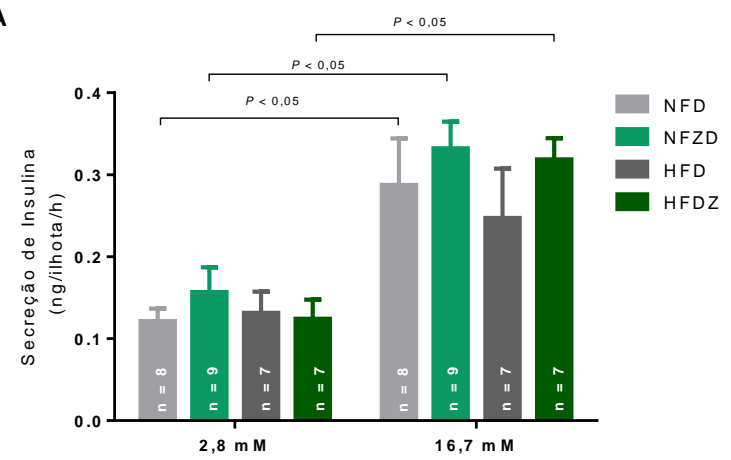

C

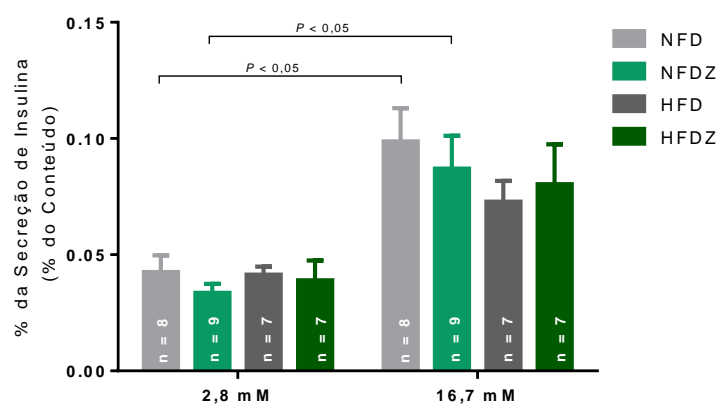

B

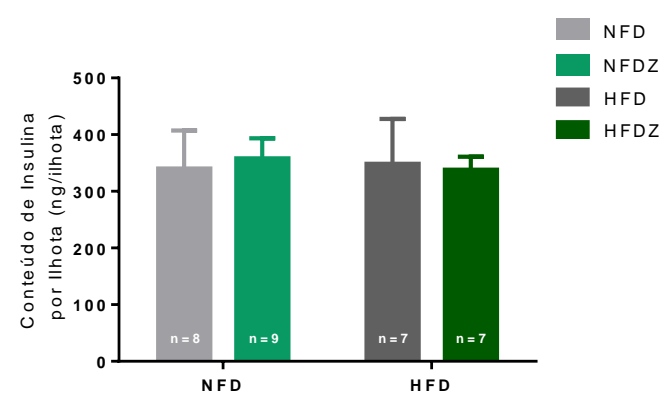

Figura 9. Ensaio estático de secreção de insulina por ilhotas isoladas estimuladas por glicose. Efeito de baixa $(2,8 \mathrm{mM})$ e alta $(16,7 \mathrm{mM})$ concentração de glicose na secreção de Insulina por llhota (ng/ilhota) (A), no conteúdo de insulina por ilhota (B) no \% da secreção de insulina (\% do Conteúdo) (C). Valores são médias \pm EPM. Secreção de Insulina por llhota: interação e ração, $P>0,05$; concentração de glicose, $P<0,001$. Conteúdo de insulina por ilhota: interação, ração e concentração de glicose, $P>0,05$. \% da secreção de insulina: interação e ração, $P>0,05$; concentração de glicose, $P<0,001$. Analisado por Two way ANOVA com pós-teste de Bonferroni. 


\subsection{Expressão das proteínas AKT e GSK3- $\beta$}

A análise da expressão proteica e da fosforilação das proteínas da via de sinalização da insulina, AKT e GSK3- $\beta$, avaliadas no tecido hepático e no músculo sóleo com e sem estímulo de insulina e as imagens do controle de caregamento das membranas coradas com vermelho de Ponceau, são mostradas na Figura 10 e 11. Em ambos os tecidos não foram encontradas diferenças estatísticas nos grupos estudados e a suplementação com o $\mathrm{ZnCl}_{2}$ não apresentou efeito favorável sobre a expressão dessas proteínas.
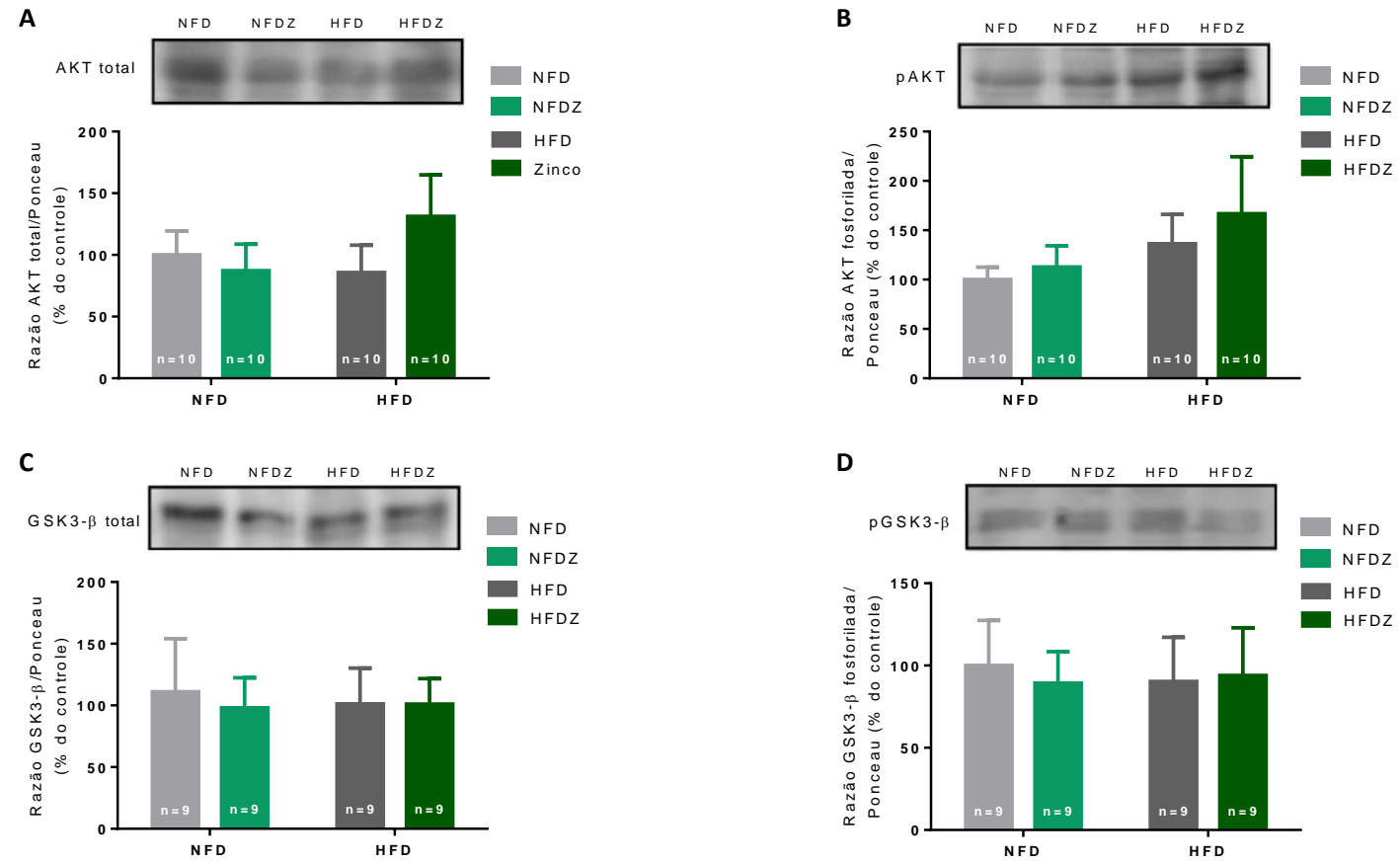

E

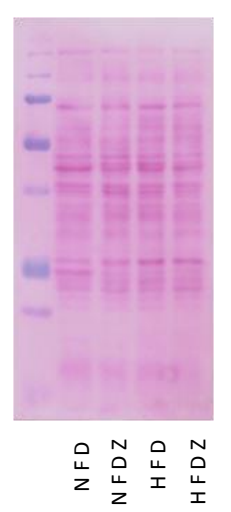

Figura 10. Efeito da suplementação com $\mathrm{ZnCl}_{2}$ sobre o conteúdo e a fosforilação de AKT e GSK3- $\beta$ no fígado de animais controles e suplementados com $\mathbf{Z n C l}_{2}$. Imagens e análise quantitativa da expressão da AKT total (A), fosfo-AKT (ser 473) (B), GSK3- $\beta$ total (C), fosfo-GSK3- $\beta$ (ser 9) (D), e imagem representativa da marcação proteica pelo ponceau em uma membrana (E). A expressão das proteínas foi normalizada por quantificação da membrana corada com ponceau. Os valores são médias \pm EPM. Interação, $P>0,05$; ração, $P>0,05$ e zinco $P>$ 0,05. Analisado por Two way ANOVA com pós-teste de Bonferroni. 
A

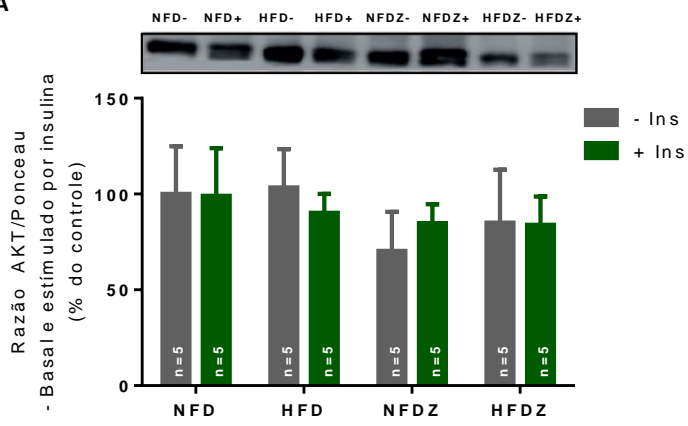

B
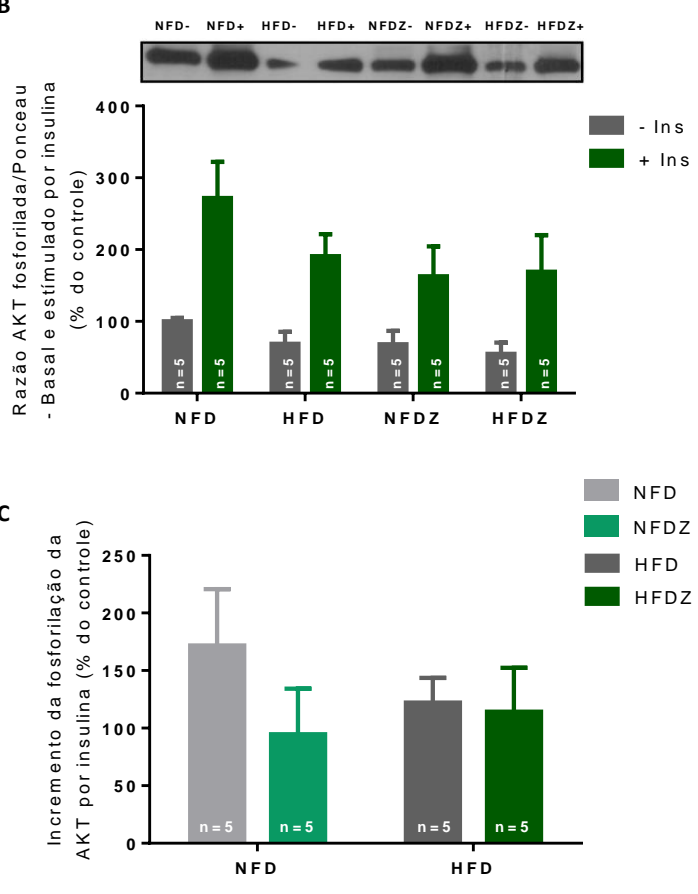

D

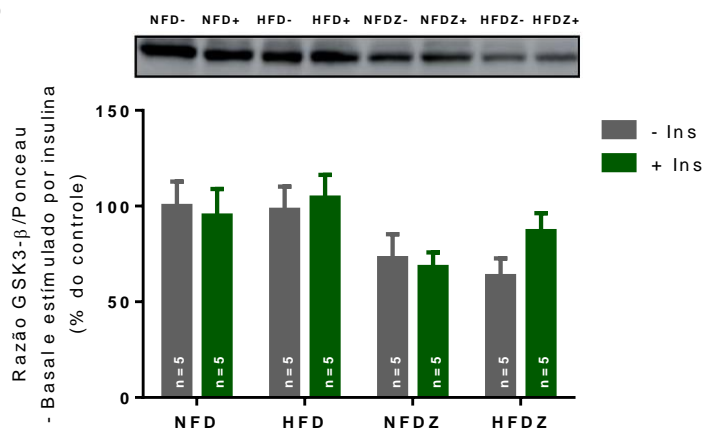

E
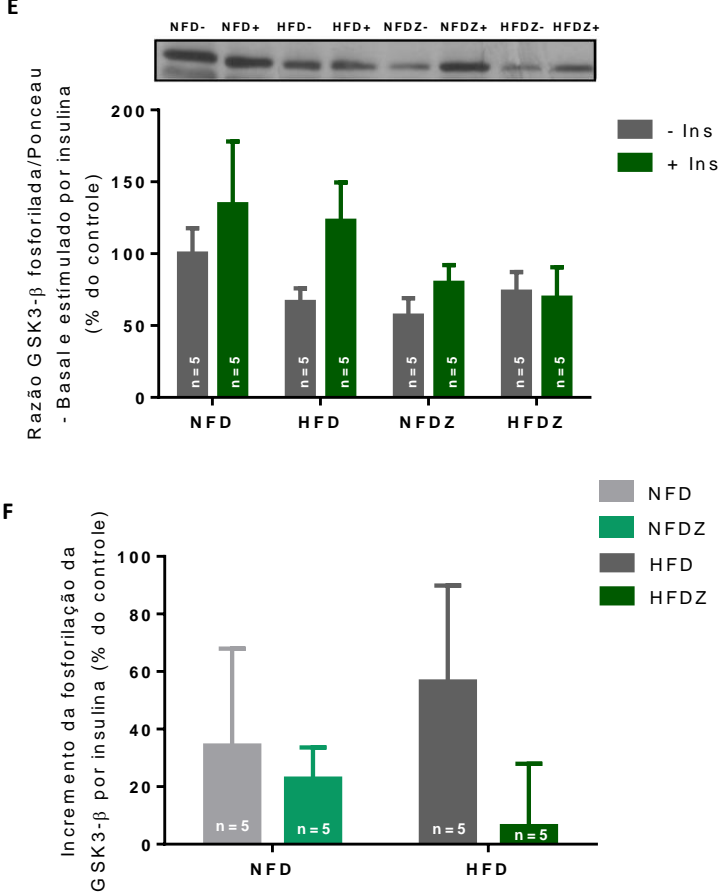

G

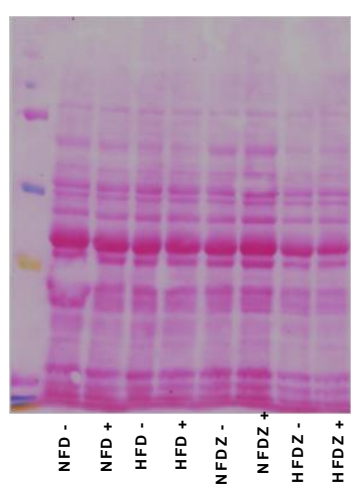

Figura 11. Efeito da suplementação com $\mathrm{ZnCl}_{2}$ sobre o conteúdo e a fosforilação de AKT e GSK3- $\beta$ no músculo sóleo, com (+Ins) e sem (-Ins) estímulo de insulina por 20 minutos, de animais controles e suplementados com $\mathrm{ZnCl}_{2}$. Quantificação da expressão da AKT total (A), fosfo-AKT (ser 473) (B), GSK3- $\beta$ total (D), fosfo-GSK3- $\beta$ (ser 9) (E) em razão da marcação proteica pelo ponceau. Quantificação do incremento na forforilação causado pelo estímulo insulínico na AKT (C) e GSK3- $\beta$ (F). Imagem representativa da marcação proteica pelo ponceau em uma membrana (G). A expressão das proteínas foi normalizada por quantificação da membrana corada com ponceau. Os valores são médias \pm EPM. Razão entre a expressão das proteinais e o ponceau (A) (B) (D) (E): Interação, ração e insulina $P>0,05$. Incremento causado pela insulina (C) (F): Interação, ração e zinco $P>0,05$. Analisado por Two way ANOVA com pós-teste de Bonferroni. 


\subsection{Captação e metabolismo de glicose}

A Figura 12 apresenta a captação de 2-deoxi-[2,6- $\left.{ }^{3} \mathrm{H}\right]$-D-glicose (Fig. 12, A), a incorporação de [U- $\left.{ }^{14} \mathrm{C}\right]$-D-glicose (Fig. 12, B), a síntese de glicogênio (Fig. 12, C) e a oxidação da glicose no músculo sóleo (Fig. 12, D) com e sem estímulo de insulina. É possível observar que houve um aumento na captação de 2-deoxi-[2,6- $\left.{ }^{3} \mathrm{H}\right]-\mathrm{D}$-glicose, na incorporação de [U${ }^{14} \mathrm{C}$ ]-D-glicose e na síntese de glicogênio nos músculos estimulados com insulina dos grupos NFD $(P>0,05)$ e NFDZ $(P>0,05)$ em relação aos músculos dos respectivos grupos que não foram incubados com esse hormônio. Por outro lado, os músculos incubados com insulina dos grupos HFD e HFDZ não apresentaram aumento significativo na captação, incorporação ou oxidação em relação aos que não foram estimulados, exceto a síntese de glicogênio no grupo HFD $(P>0,05)$, que se mostrou maior com o estímulo desse hormônio. Dessa forma, os dados obtidos sugerem que a ração hiperlipídica favoreceu o surgimento da resistência à insulina e que a suplementação com o $\mathrm{ZnCl}_{2}$ não foi eficaz na melhora desse quadro. 
A

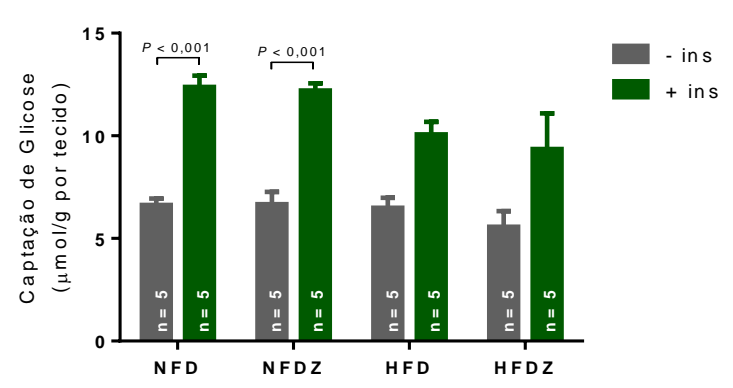

C

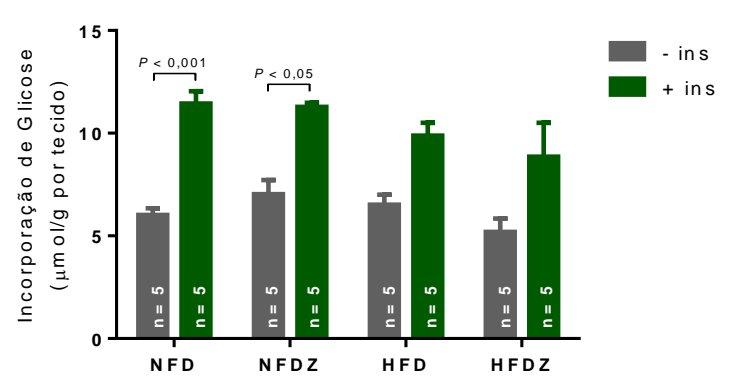

E

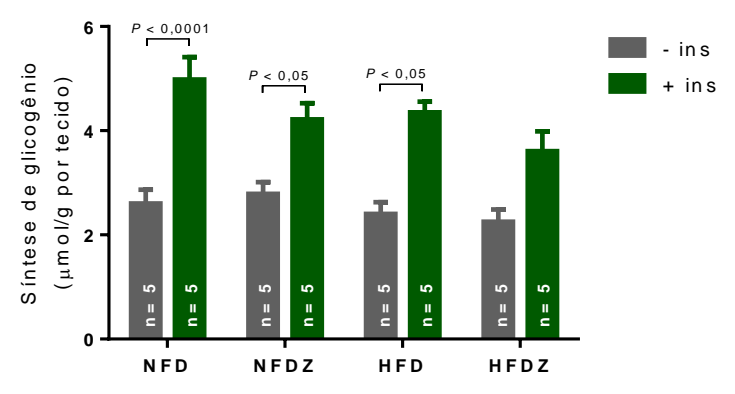

G

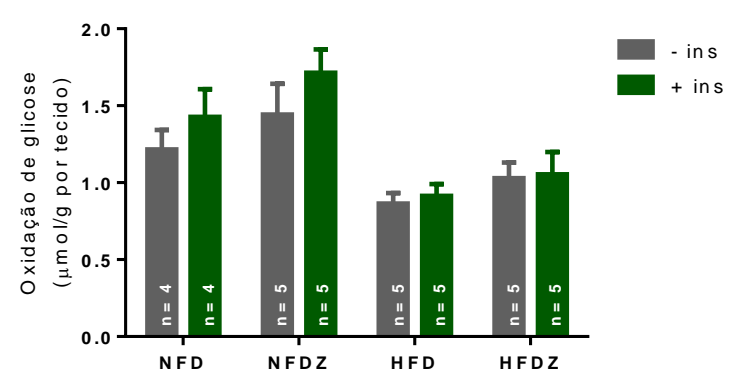

B

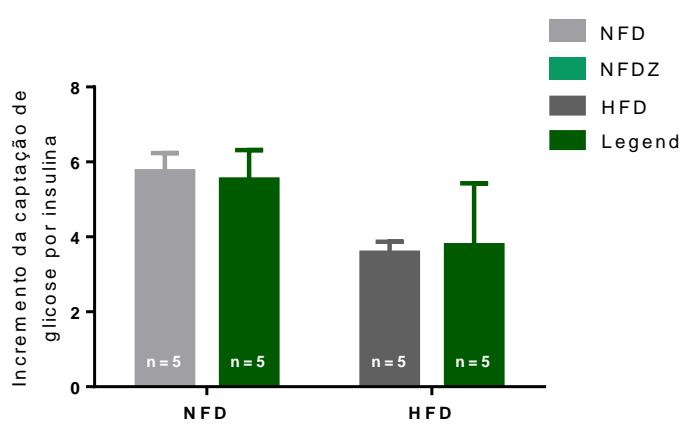

D

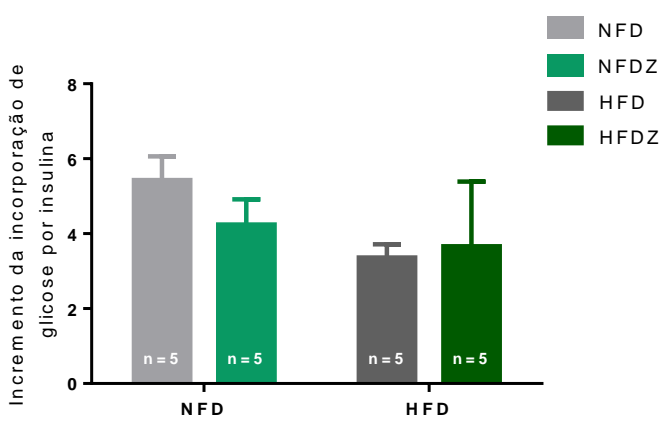

F

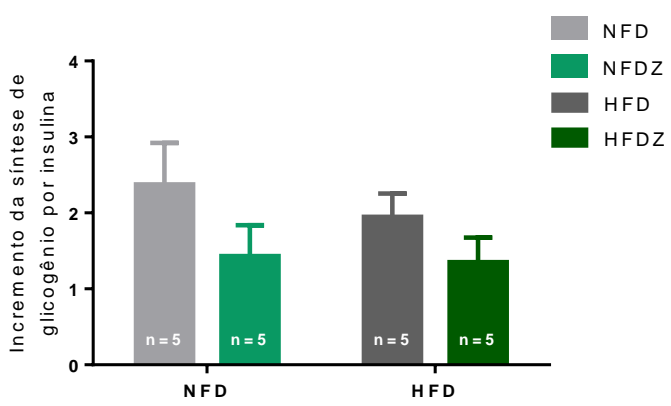

H

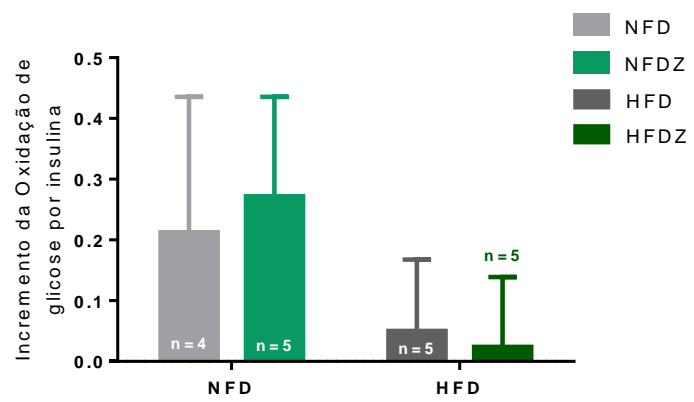

Figura 12. Captação e metabolismo de glicose com (+ins) e sem (-ins) estímulo de insulina por 60 minutos em músculo sóleo isolado de animais controles e suplementados com $\mathrm{ZnCl}_{2}$. A captação de glicose $(A)$, a incorporação de glicose total (C), e a síntese de glicogênio (E) foram avaliados no músculo sóleo e a oxidação de glicose (G) foi avaliada a partir da produção de ${ }^{14} \mathrm{CO}_{2}$. Incremento da captação de glicose (B), da incorporação de glicose (D), da síntese de glicogênio (F) e da oxidação de glicose $(H)$ causado pelo estímulo insulínico. Os valores são médias \pm EPM. Captação de glicose: interação, $P>0,05$; ração, $P<0,05$; e insulina, $P<$ 0,001 . Incorporação de glicose: interação e ração, $P>0,05$; e insulina, $P<0,001$. Síntese de glicogênio: interação, $P>0,05$; ração, $P<0,05$; e insulina, $P<0,001$. Oxidação de glicose: interação e insulina $P>0,05$; e ração, $P<0,001$. Incremento causado pela insulina (B) (D) (F) (H): interação, ração e zinco $P>0,05$. Analisado por Two way ANOVA com pós-teste de Bonferroni. 


\section{DISCUSSÃO}

A ração hiperlipídica foi capaz de gerar um modelo válido de roedor obeso, com resistência à insulina e hiperglicemia, características típicas do DM2. Por outro lado, a suplementação com $\mathrm{ZnCl}_{2}$ mostrou-se, ao longo do tratamento, eficiente no aumento da concentração plasmática de zinco e na melhora do quadro de disfunção glicêmica induzido por ração hiperlipídica em camundongos, aparentemente por um efeito positivo sobre as células $\beta$, sem no entanto afetar o ganho de massa corporal, a secreção de insulina por ilhotas isoladas, a sensibilidade periférica a esse hormônio no fígado e no músculo sóleo e a captação e o metabolismo de glicose no músculo sóleo.

O aumento da concentração plasmática de zinco entre os animais dos grupos NFDZ e HFDZ foi devido a suplementação com $\mathrm{ZnCl}_{2}$, que aumentou consideravelmente a ingestão de zinco entre os animais que receberam a suplementação em relação aos que não receberam. A ingestão excessiva de zinco por longos períodos pode interferir com o metabolismo do ferro e do cobre, comprometer o sistema imune e reduzir as concentrações de HDL-colesterol (SAPER; RASH, 2009; FOSMIRE, 1980). Entretanto, nesse estudo não foram avaliadas marcadores bioquímicos válidos para a avaliação nutricional do ferro e do cobre, da concentração de HDL-colesterol ou outros parâmetros, não sendo possível saber se a suplementação com o $\mathrm{ZnCl}_{2}$ provocou efeitos adversos. Além disso, não foram relatados indícios de intoxicação ou efeitos adversos entre os camundongos C57BL/6J (ob/ob) que receberam a suplementação com o $\mathrm{ZnCl}_{2}$ a $20 \mathrm{mM}$ na água ad libitum por oito semanas (CHEN et al., 1998). A toxicidade oral por $\mathrm{ZnCl}_{2}$, em ratos, foi relatada a partir da ingestão de $350 \mathrm{mg} / \mathrm{Kg}(0,35 \mathrm{mg} / \mathrm{g})$ (LEWIS, 1996), mas nenhum dos grupos suplementados atingiu esse valor.

Embora alguns trabalhos relatem a deficiência de zinco no soro e no plasma de indivíduos com DM2 (GARG; GUPTA; GOYAL, 1994; KINLAW et al., 1983; SOINIO et al., 2007; VIKTORÍNOVÁ et al., 2009), os resultados mostram que os animais do grupo HFD que apresentaram características típicas do DM2, tinham uma concentração de zinco semelhante à do grupo NFD. A concentração de zinco no soro reflete o status desse mineral em curto período de tempo e é dependente da ingestão do mesmo (LOWE, FEKETE, DECSI, 2009), sendo sugerido que a análise da concentração de zinco eritrocitária seja mais adequada que a do plasma ou do soro para avaliar o estado nutricional desse mineral, por refletir um 
estado nutricional de períodos mais longos (KRUSE-JARRES; RÜKGAUER, 2000). Dessa forma, caso a análise da concentração de zinco eritrocitária fosse realizada, é possível que essa mostrasse um estado de deficiência desse mineral entre os animais do grupo HFD, já que o zinco eritrocitário reflete um estado nutricional do zinco por períodos mais longos e a deficiência desse mineral em DM2 é relatada por outros trabalhos conforme citado.

O tratamento com a ração hiperlipídica foi responsável pela maior massa corporal entre os animais do grupo HFD e HFDZ em relação aos animais dos grupos NFD e NFDZ, confirmando ser eficiente na geração de um modelo válido de roedor obeso. $\mathrm{O}$ ganho de massa corporal entre os animais alimentados com HFD é explicado, ao menos em parte, pela maior densidade energética da ração hiperlipídica à qual foram expostos durante o tratamento. Ao mesmo tempo, a alta densidade energética da ração é responsável pela menor ingestão da mesma (HERBERG et al., 1974). Isso justifica a menor ingestão diária de ração entre os animais do grupo HFD e HFDZ, em comparação com os animais do grupo NFD e NFDZ, respectivamente. Embora a ingestão diária, em gramas, da ração hiperlipídica tenha se apresentado um pouco menor que a ração normolipídica, a ingestão calórica foi maior nos grupos alimentados com ração hiperlipídica. É sabido que as gorduras oferecem mais quilocalorias (kcal) por grama de peso que carboidratos e proteínas. Segundo Gallagher (2010), cada grama ingerida de carboidrato ou proteína proporciona ao organismo aproximadamente $4 \mathrm{kcal}$ e cada grama de gordura fornece por volta de $9 \mathrm{kcal}$, o que explica a maior densidade calórica da ração hiperlipídica, que apresentava $60 \%$ de sua composição em gorduras.

O tipo de gordura usada na composição da ração, independente de uma maior ingestão calórica, também contribui para a maior adiposidade entre animais alimentados com HFD. Segundo Buettner et al. (2006), as gorduras saturadas e monoinsaturadas promovem a obesidade e a resistência à insulina de modo mais eficiente que as gorduras poli-insaturadas e outros macronutrientes. Indo ao encontro da metodologia empregada em nosso trabalho, os autores ainda afirmam que a banha de porco, uma mistura de gordura saturada e monoinsaturada, é a mais eficiente na geração de um modelo válido de roedor obeso e com alterações metabólicas, como a resistência à insulina e o DM2.

Apesar de a ração hiperlipídica ter sido responsável pela obesidade entre os animais dos grupos HFD e HFDZ, é possível observar que a suplementação com o $\mathrm{ZnCl}_{2}$ não apresentou efeito sobre o controle do ganho de massa corporal, visto que os grupos 
controle e os suplementados com $\mathrm{ZnCl}_{2}$ apresentaram ganho de massa corporal semelhante no final do tratamento. Por outro lado, é sugerido que o zinco auxilie no controle da massa corporal aumentando a secreção de leptina. Foi mostrado que em camundongos C57BL/6J a suplementação com o zinco está envolvida com o aumento na secreção de leptina (CHEN et al., 2001). Em humanos, a suplementação com zinco também aumentou a secreção de leptina e as concentrações de interleucina-2 (IL-2) e Fator de Necrose tumoral alfa (TNF- $\alpha$ ), mas não ficou claramente definido se esse mineral regula a expressão da leptina diretamente ou indiretamente por meio do aumento da produção dessas citocinas (MANTZOROS et al., 1998).

Apesar de não terem sido avaliadas as concentrações plasmáticas de leptina, a sua concentração plasmática está correlacionada com a quantidade de gordura corporal (KELESIDIS et al., 2010). Esse hormônio modula o funcionamento de regiões hipotalâmicas, interferindo negativamente na ingestão energética, auxiliando no controle do acúmulo de gordura corporal (ZHANG et al., 1994). Dessa forma, os estímulos que aumentam a concentração plasmática de leptina levam ao aumento dos sinais de saciedade, causando a diminuição da ingestão alimentar e o controle da massa corporal. Entretanto, não foram observados a diminuição da ingestão de ração e o consequente controle da massa corporal entre os animais do grupo HFDZ. Por outro lado, é sugerida a ressitência à leptina em camundongos C57BL/6J com obesidade induzida por ração hiperlipídica durante desesseis semanas de tratamento (MÜNZBERG; FLIER; BJØRBAEK, 2004), o que pode ter impedido a observação do efeito de um possível aumento da leptinemia nos animais do grupo HFDZ que apresetaram obesidade. Além disso, o zinco apresenta uma atividade antilipolítica em adipócitos, sendo que o tratamento com zinco e insulina causou um aumento da lipogênese em camundongos C57BL/6J (ob/ob) (CHEN et al., 1998), o que diminui a possibilidade da suplementação com esse mineral desencadear a perda de gordura corporal. Dessa forma, mesmo que exista um aumento da leptinemia, pode haver uma ressitência a esse hormônio e, ao mesmo tempo, o zinco não apresenta outro efeito que cause a diminuição da ingestão alimentar e da gordura corporal.

Para além da obesidade, a oferta de uma ração rica em gordura, principalmente gordura saturada, também está associada com a resistência à insulina e a hiperglicemia (BURCELIN et al., 2002; WEST; YORK, 1998). Os resultados do HOMA-IR, da constante de decaimento da glicose (KITT), da captação e metabolismo da glicose e da glicemia de 
privação alimentar indicam que os animais dos grupos que receberam ração hiperlipídica apresentaram considerável resistência à insulina e hiperglicemia em relação aos animais que receberam ração normolipídica, exceto os animais do grupo HFDZ, que não apresentaram hiperglicemia, apenas resistência à insulina.

Ao contrário dos animais que receberam ração hiperlipídica, os grupos que foram alimentados com ração normolipídica apresentaram uma manutenção da massa corporal saudável e valores normais de glicemia, uma vez que os animais desses grupos não apresentaram obesidade, resistência à insulina e hiperglicemia. Mesmo apresentando resistência à insulina, os animais do grupo HFDZ apresentaram menores valores de glicemia ao longo do tratamento em relação ao grupo HFD e menor glicemia de privação alimentar após o tratamento, mostrando que a suplementação com o $\mathrm{ZnCl}_{2}$ foi capaz de manter a glicemia em valores próximos aos dos animais dos grupos NFD e NFDZ, mesmo com a resistência à insulina instalada.

Chen et al. (1998) mostraram que a suplementação com 20 mM de $\mathrm{ZnCl}_{2}$ em água ad libitum durante oito semanas em camundongos C57BL/6 (ob/ob) reduziu a glicemia de jejum nos camundongos magros e obesos em 25 e 21\%, respectivamente, quando comparados ao controle, sugerindo que a suplementação com zinco pode estar associada com a melhora na atividade da insulina. No entanto, em nosso estudo, a suplementação com $\mathrm{ZnCl}_{2}$ reduziu a glicemia de jejum em 20,5\% no grupo dos animais HFDZ comparado ao HFD, mas não houve diminuição estatística da glicemia de jejum dos animais do grupo NFDZ em relação ao grupo NFD. A diferença no modelo experimental e no tempo de tratamento utilizado por Chen et al. (1998), em relação aos nossos experimentos, pode ter sido a responsável por não ter ocorrido diferença estatística entre a glicemia dos grupos NFD e NFDZ, apesar da diminuição da glicemia entre os animais obesos ter sido similar entre ambos estudos.

Apesar da participação do zinco na melhora da resistência à insulina e na via de sinalização intracelular desse hormônio ser sugerida por alguns estudos (COULSTON; DANDONA, 1980; FAURE et al., 1992; HAASE; MARET, 2015; ILOUZ et al., 2002; TANG; SHAY, 2001; YOSHIKAWA et al., 2004), os resultados apresentados pelo HOMA-RI, a constante de decaimento da glicose (KITT), a análise da expressão proteica e da fosforilação das proteínas AKT e GSK3- $\beta$ na via de sinalização da insulina no fígado e no músculo e a captação e metabolismo de glicose no músculo sóleo, não apresentaram diferenças favoráveis à suplementação com o $\mathrm{ZnCl}_{2}$ entre os grupos HFD e HFDZ. Esses resultados mostram que a 
suplementação com o $\mathrm{ZnCl}_{2}$ não melhorou a resistência periférica a esse hormônio, apesar de outros autores mostrarem que a suplementação com o zinco pode aumentar e/ou mimetizar a ação da insulina no tecido adiposo (BASUKI; HIROMURA; SAKURAI, 2007; NAITO; YOSHIKAWA; YASUI, 2011; NAKAYAMA et al., 2008; YOSHIKAWA et al., 2004).

Embora não tenha sido avaliada a via de sinalização da insulina em adipócitos neste estudo, outros grupos mostraram que nessas células o zinco mimetizou o efeito da insulina, ao aumentar a captação de glicose (TANG; SHAY, 2001; YOSHIKAWA et al., 2004). O tratamento de adipócitos com zinco apresentou um efeito semelhante à insulina, aumentando o transporte de glicose mediado por PI3-K e AKT (TANG; SHAY, 2001). Nesse mesmo tipo celular, a suplementação do meio com zinco levou ao aumento da fosforilação da GSK3- $\beta$ (NAITO; YOSHIKAWA; YASUI, 2011). Contudo, a contribuição do tecido adiposo para o metabolismo da glicose é pequena, pois no estado pós-prandial aproximadamente $80 \%$ da captação de glicose ocorre no músculo esquelético (THIEBAUD et al., 1982), que é quantitativamente o principal sítio da resistência à insulina no DM2 (DEFRONZO et al., 1985), sendo que apenas uma possível melhora da resistência à insulina no tecido adiposo contribuiria pouco para a melhora geral da resistência a esse hormônio em todo o organismo, conforme indicam os resultados aqui apresentados.

Dessa forma, apesar de não ter sido avaliada, pode ter havido uma melhora na resistência à insulina no tecido adiposo, mas provavelmente não foi suficiente para reverter o quadro geral de resistência a esse hormônio. Uma vez que a partir dos dados obtidos em fígado e músculo, através de immunoblotting para a quantificação das proteínas AKT e GSK3$\beta$, nota-se não ter ocorrido uma melhora na resistência à insulina com o aumento na fosforilação dessas proteínas nesses tecidos. Além disso, a captação e o metabolismo da glicose no músculo sóleo se mostraram resistentes à insulina nos animais dos grupos HFD e HFDZ. Entretanto, mesmo com uma ressistência à insulina instalada, o resultado do metabolismo no músculo sóleo mostra que esse hormônio conseguiu aumentar a síntese de glicogênio entre os animais do grupo HFD, mas a síntese de glicogênio estímulada por insulina foi maior entre os animais do grupo NFD.

De maneira geral, é clara a instalação da resistência à insulina nos tecidos avaliados e que a suplementação com o $\mathrm{ZnCl}_{2}$ não melhorou esse quadro. Indo ao encontro de parte dos dados apresentados, Simon e Taylor (2001) mostaram ao avaliar se o zinco desempenha um papel importante na modulação da atividade tirosina cinase do receptor da insulina no 
músculo gastrocnêmico de camundongos $\mathrm{db} / \mathrm{db}$ (um modelo genético de $\mathrm{DM} 2$ ), que não houve melhora considerável na atividade tirosina cinase desse receptor em animais suplementados com 300 ppm de zinco por seis semanas, confirmando que a resistência à insulina em músculo esquelético não é amenizada ou revertida através da suplementação com o zinco.

O efeito hipoglicemiante do zinco em camundongos C57BL/6J hiperglicêmicos também pode ser parcialmente atribuído ao aumento da leptinemia induzida por esse mineral (CHEN et al., 2001). A leptina parece atuar sobre a via de sinalização da insulina, promovendo melhor sinalização insulínica. De acordo com Kamohara et al. (1997), a infusão intravenosa de leptina em camundongos C57BL/6J estimulou a captação de glicose no músculo esquelético e tecido adiposo. Por outro lado, outros autores mostraram que esse hormônio pode antagonizar a ação da insulina, diminuindo a expressão da glicoquinase (ROSSETTI et al., 1997) e aumentando a expressão da PEPCK (LIU et al., 1998; ROSSETTI et al., 1997). No entanto, permanece controverso se essas ações da leptina são mediadas direta ou indiretamente. Apesar dessas evidências e dos resultados aqui apresentados mostrarem melhor controle glicêmico no grupo HFDZ em relação ao grupo HFD, não foram avaliados os níveis plasmáticos de leptina, impossibilitando estabelecer uma relação entre o melhor controle glicêmico dos animais do grupo HFDZ e os níveis circulantes desse hormônio.

É possível que além de ter causado obesidade, resistência à insulina e hiperglicemia, a ração hiperlipídica tenha levado a prejuízos na função das células $\beta$. O efeito de uma ração hiperlipídica sobre a função pancreática das células $\beta$ vem sendo estudado por vários grupos (GONZALEZ et al., 2013; KARASAWA et al., 2009; REIMER; AHREN, 2002; SONE; KAGAWA, 2004). Após uma ração com $60 \%$ gordura por doze semanas, camundongos fêmea C57BL/6, apresentaram hipertrofia e hiperplasia das células $\beta$, aumento na secreção de insulina, resistência à insulina e moderada intolerância à glicose (GONZALEZ et al., 2013). Contudo, os autores sugerem que esses efeitos podem estar relacionados a mecanismos compensatórios pré-diabéticos, em que alterações estruturais de células $\beta$ ocorrem, opondo-se a resistência à insulina, permitindo a normalização da glicemia. Mas com o tempo, essa adaptação pode vir a falhar e a progressão para a hiperglicemia e o DM2 pode eventualmente ocorrer. Por outro lado, Kim et al. (1995) conseguiram relatar uma deterioração funcional das células $\beta$ em ratos machos da linhagem Sprague-Dawley alimentados com uma ração hiperlipídica 
contendo apenas $40 \%$ de gordura por somente quatro semanas, sendo também observada a redução na transcrição dos genes do transportador de glicose GLUT2 e da glicoquinase.

Em nosso estudo, durante o tratamento com a ração hiperlipídica, os animais do grupo HFD apresentaram a maior média de glicemia na quarta semana de tratamento, sugerindo resistência à insulina e/ou um mau funcionamento das células $\beta$, o que nesse caso pode corroborar os resultados de deterioração funcional das células $\beta$ relatado por Kim et al. (1995) na quarta semana de tratamento com ração hiperlipídica. É possível que, com a continuidade do tratamento para além das quatro semanas, conforme observado no estudo de Gonzalez et al. (2013), ocorra uma adaptação funcional nas células $\beta$, para a normalização da glicemia, mas se a ingestão dessa ração se estender por um tempo ainda maior, ocorrerá então, conforme apresentado por Collins et al. (2010), após 15 semanas de tratamento com uma ração rica em gordura, a hiperglicemia e a hipoinsulinemia nos animais tratados.

O resultado do $H O M A-\beta$, feito a partir da glicemia e insulinemia de privação alimentar de oito horas, não mostra diferenças entre os grupos NFD e HFD, indicando que, após esse período de privação alimentar, possivelmente o tempo do tratamento e a composição da ração hiperlipídica não contribuíram para o mau funcionamento das células $\beta$, ou, se contribuíram, houve uma resposta compensatória por parte dessas células, na tentativa de reverter à hiperglicemia, mas com a continuidade do tratamento seria possível que os animais apresentassem uma falência das células $\beta$. Uma vez que, quando as ilhotas do grupo HFD foram incubadas com 16,7 mM de glicose, elas não apresentaram aumento em relação às ilhotas do mesmo grupo incubadas com 2,8 mM de glicose. Indicando um possível mau funcionamento das células $\beta$ em altas concentrações de glicose, momento no qual o aumento da secreção de insulina se faz ainda mais necessário para a captação de glicose.

Por outro lado, mesmo o grupo HFDZ não apresentando um aumento significativo no na secreção estática de insulina em relação ao grupo HFD, na análise de $H O M A-\beta$ o tratamento com o $\mathrm{ZnCl}_{2}$ foi relacionado ao aumento da eficiência dessas células por parte da análise estatística aplicada. Aliás, o melhor controle glicêmico e, principalmente, a menor AUC dos valores de glicemia durante o ipGTT, um método que prediz a secreção de insulina, dos animais do grupo HFDZ, sugerem que, em relação ao grupo HFD, houve um melhor funcionamento das células $\beta$, já que a glicemia desse grupo conseguiu se normalizar após 90 a 100 minutos da administração de glicose, ao contrário do grupo HFD. Desse modo, o 
reestabelecimento dos níveis de glicemia no grupo HFDZ ao final do ipGTT reforça a hipótese de uma melhor tolerância à glicose quando comparados ao grupo HFD, sugerindo que a suplementação com o zinco tenha exercido uma possível melhora na funcionalidade da célula $\beta$ in vivo.

O efeito da suplementação com zinco na insulinemia também foi avaliado por Chen et al. (1998), sendo demonstrado que os níveis plasmáticos de insulina no jejum foram menores em camundongos $\mathrm{C} 57 \mathrm{BL} / 6 \mathrm{~J}$ geneticamente obesos (ob/ob) após o tratamento com $\mathrm{ZnCl}_{2}$ por oito semanas. Contudo, os nossos resultados de insulinemia foram diferentes, com uma maior média de insulinemia entre os animais suplementados, apesar de não haver diferença estatística. A diferença no tempo de tratamento e, principalmente, no modelo experimental, entre o nosso estudo e o realizado por Chen et al. (1998), pode ter sido a responsável por haver disparidade entre os nossos resultados de insulinemia, pois in vitro o zinco demonstrou-se eficiente na melhora da secreção desse hormônio (NYGAARD et al., 2014). Além disso, o nosso modelo animal teve a manifestação do quadro metabólico comprometido de forma mais próxima da natural, sendo que os animais eram sedentários e consumiam uma ração hiperlipídica com baixo teor de fibras, acarretando a obesidade, a resistência à insulina e a hiperglicemia.

Embora o ensaio de secreção estática de insulina não tenha mostrado um aumento significativo na secreção desse hormônio no grupo HFDZ em relação ao HFD, usando a linhagem de células $\beta$ INS-1E, Nygaard et al. (2014) demonstraram que a suplementação do meio de cultura com $\mathrm{ZnCl}_{2}$ em diferentes concentrações afetou a secreção de insulina e, além disso, a sobrevivência das células $\beta$, sugerindo que a regulação da homeostase de zinco pode representar um alvo farmacológico para o tratamento do diabetes. Os autores observaram que a suplementação com 0,02 mM de $\mathrm{ZnCl}_{2}$ aumentou a secreção de insulina significantemente em relação ao controle. Entretanto, a expressão do gene da insulina e a viabilidade celular foi reduzida após a exposição das células INS-1E a concentrações citotóxicas de $\mathrm{ZnCl}_{2}\left(0,4\right.$ a 1,0 mM), pois observaram que o $\mathrm{ZnCl}_{2}$ em concentrações de até $0,1 \mathrm{mM}$ é bem tolerado pelas células INS-1E, mas aumentando a concentração para 0,2 a 1 $\mathrm{mM}$, ocorre morte celular. Além disso, essa suplementação interferiu na homeostase do zinco através do aumento da expressão gênica do ZnT3, ZnT8 e MT1A.

É sugerido que a suplementação com o zinco também module a expressão de proteínas ZnF (PRASAD et al., 2004). Dentre os ZnF conhecidos, o Tshz1 é um fator 
transcricional que regula a proliferação celular, diferenciação e manutenção de célulastronco durante o desenvolvimento de moscas (Drosophila). Em mamíferos, pouco é conhecido sobre o seu papel biológico, mas já é sabido que a deleção do Tshz1 resulta em defeitos no esqueleto, orelha e na formação do palato, bem como no desenvolvimento neuronal e função do bulbo olfatório (CORÉ et al., 2007). Em camundongos adultos deficientes em Tshz1 foi observada diminuição na secreção de insulina e uma expressão deficiente desse mesmo $\mathrm{ZnF}$ foi encontrada em ilhotas humanas de indivíduos com DM2 (RAUM et al., 2015). Outro ZnF presente em células $\beta$ é o Glis3 que é tanto um repressor com um ativador de transcrição gênica e sua deficiência tem sido associada ao desenvolvimento de DM1, 2 e neonatal (LICHTI-KAISER et al., 2012). No pâncreas ele está envolvido com o desenvolvimento e manutenção de células $\beta$ e na expressão gênica da insulina, interagindo com fatores chaves de sua transcrição, como o Pancreatic Duodenal Homeobox 1 (Pdx1), Musculoaponeurotic fibrosarcoma oncogene homolog A (MafA) e neuronal differentiation 1 (NeuroD1), regulando sinergicamente a transcrição do gene da insulina (YANG et al., 2009). Podendo a suplementação com o zinco modular a expressão de proteínas necessárias para a sua homeostase e de alguns $\mathrm{ZnF}$, torna-se coerente pensar que essa suplementação também possa intervir na expressão do Tshz1 e do Glis3 em células $\beta$.

Além de efeitos diretos sobre o controle homeostático de células $\beta$ (NYGAARD et al., 2014), a suplementação com o zinco vem sendo há algum tempo relacionada com melhorias na atividade antioxidante dessas células (BOSCO et al., 2010; DUPREZ et al., 2012). In vitro, $50 \mu \mathrm{M}$ de $\mathrm{ZnCl}_{2}$ por aproximadamente 24 horas reduziram o estresse oxidativo mitocondrial e a apoptose em células $\beta$ de rato, mas não melhoraram a secreção de insulina induzida por glicose (DUPREZ et al., 2012). Em um estudo realizado por Roussel et al. (2003), 56 indivíduos com DM2 suplementados com $30 \mathrm{mg}$ de zinco/dia por seis meses, foi inferida uma diminuição significativa na peroxidação lipídica no plasma, sugerida pela observação da diminuição plasmática de substâncias reativas ao ácido tiobarbitúrico que são importantes indicadores da peroxidação lipídica, indicando que a suplementação com o zinco poderia melhorar a resistência à insulina em DM2 devido à sua função antioxidante, diminuindo a peroxidação lipídica plasmática e a formação de radicais livres.

Embora a literatura apresente diversos mecanismos pelos quais o zinco possa atuar sobre o controle da glicemia através de melhorias na resistência à insulina em adipócitos e na função da célula $\beta$, o presente trabalho mostra que o zinco não melhorou a resistência à 
insulina no fígado e no músculo sóleo. Por outro lado, apesar de não ter melhorado a secreção de insulina por ilhotas isoladas, in vivo, a suplementação com esse mineral foi capaz de controlar a glicemia de animais obesos e com resistência à insulina e possivelmente melhorar a função das células $\beta$ sugerido pelo resultado do ipGTT e parcialmente pelo HOMA- $\beta$. Dentre os possíveis mecanismos responsáveis por essa melhora, destacam-se o provável efeito do zinco sobre a expressão e/ou manutenção de proteínas chaves no processamento da insulina em células $\beta$, como os transportadores de zinco, as MT, a enzima antioxidante Cu-Zn SOD, e os ZnF Tshz1 e Glis3, que desempenham um papel fundamental na regulação da transcrição de insulina. O estudo do efeito do zinco na expressão dessas proteínas pode servir como um importante alvo terapêutico para o tratamento do diabetes. Pouco se conhece sobre as diferentes ações das proteínas Tshz1 e Glis3 em células $\beta$, e a sua elucidação será crucial para a compreensão de suas funções biológicas e para a descoberta de oportunidades terapêuticas para o tratamento do DM. 


\section{CONCLUSÃO}

Os dados obtidos demonstram que a suplementação com $\mathrm{ZnCl}_{2}$ melhorou o quadro de disfunção glicêmica induzido por ração hiperlipídica, aparentemente por um efeito positivo sobre a função da célula $\beta$, sem afetar a sensibilidade periférica à insulina no fígado e no músculo e o ganho massa corporal. Parece haver um melhor funcionamento das células $\beta$ dos animais suplementados, sugerido (1) pelo melhor controle glicêmico e uma menor área sob a curva dos animais suplementados durante o ipGTT, (2) pelo menor resultado da glicemia de privação alimentar no grupo HFDZ em relação ao grupo HFD e (3) pelo possível efeito do zinco sobre a capacidade secretória dessas células, apresentado pelo HOMA- $\beta$, no grupo HFDZ em relação ao HFD.

Esses resultados indicam uma melhora na função das células $\beta$ dos animais suplementados e, como consequência, um melhor controle glicêmico. Mesmo não tendo sido identificado o mecanismo por trás da melhora na função dessas células, os resultados mostram que a suplementação com o $\mathrm{ZnCl}_{2}$ consegue retardar a manifestação do $\mathrm{DM} 2 \mathrm{em}$ modelo de camundongo em que a doença é induzida por ração hiperlipídica. Portanto, entende-se que o conhecimento da relação entre o zinco e os mecanismos subjacentes ao controle da síntese e secreção de insulina em células $\beta$ seja o foco de intensas pesquisas que procurem desvendar possíveis mecanismos que justifiquem a utilização do zinco na prevenção ou retardo da manifestação do DM2. 


\section{REFERÊNCIAS*}

AMERICAN DIABETES ASSOCIATION (ADA). Diagnosis and classification of diabetes mellitus. Diabetes Care, v. 38, n. 1, p. S8-S16, 2015.

ARQUILLA, E. R.; THIENE, P.; BRUGMAN, T.; RUESS, W.; SUGIYAMA, R. Effects of zinc ion on the conformation of antigenic determinants. Biochem. J., v. 175, n. 1, p. 289-297, 1978.

BASUKI, W.; HIROMURA, M.; SAKURAI, H. Insulinomimetic Zn complex (Zn(opt)2) enhances insulin signaling pathway in 3 T3-L1 adipocytes. J. Inorg. Biochem., v. 101, n. 4, p. 692-699, 2007.

BELLOMO, E. A.; MEUR, G.; RUTTER, G. A. Glucose regulates free cytosolic $\mathrm{Zn}^{2+}$ concentration, Slc39 (ZiP), and metallothionein gene expression in primary pancreatic islet $\beta$ cells. J. Biol. Chem., v. 286, n. 29, p. 25778-25789, 2011.

BERGMAN, R. N.; ADER, M.; HUECKING, K.; CITTERS, G. V. Accurate assessment of beta-cell function: the hyperbolic correction. Diabetes, v. 51, n. 1, p. 212-220, 2002.

BOESGAARD, T. W.; ZILINSKAITE, J.; VÄNTTINEN, M.; LAAKSO, M.; JANSSON, P. A.; HAMMARSTEDT, A.; SMITH, U.; STEFAN, N.; FRITSCHE, A.; HÄRING, H.; HRIBAL, M.; SESTI, G.; ZOBEL, D.P.; PEDERSEN, O.; HANSEN, T.; EUGENE, 2 C. The common SLC30A8 Arg325Trp variant is associated with reduced first-phase insulin release in 846 non-diabetic off spring of type 2 diabetes patients-the EUGENE2 study. Diabetologia, v. 51, n. 5, p. 816-820, 2008.

BONORA, E.; MOGHETTI, P.; ZANCANARO, C.; CIGOLINI, M.; QUERENA, M.; CACCIATORI, V.; CORGNATI, A.; MUGGEO, M. Estimates of in vivo insulin action in man: comparison of insulin tolerance tests with euglycemic and hyperglycemic glicose clamp studies, J. Clin. Endocrinol. Metab., v. 68, n. 2, p. 374-378, 1989.

BONORA, E.; TARGHER, G.; ALBERICHE, M.; BONADONNA, R. C.; SAGGIANI, F.; ZENERE, M. B.; MONAUNI, T.; MUGGEO, M. Homeostasis model assessment closely mirrors the glucose clamp technique in the assessment of insulin sensitivity: studies in subjects with various degrees of glucose tolerance and insulin sensitivity. Diabetes Care, v. 23, n. 1, p. 57-63, 2000.

BOURA-HALFON, S.; ZICK, Y. Phosphorylation of IRS proteins, insulin action, and insulin resistance. Am. J. Physiol. Endocrinol. Metab., v. 296, n. 4, p. E581-E591, 2005.

BOWE, J. E.; FRANKLIN, Z. J.; HAUGE-EVANS, A. C.; KING, A. J.; PERSAUD, S. J.; JONES, P. M. Metabolic phenotyping guidelines: assessing glucose homeostasis in rodent models. J. Endocrinol., v. 222, n. 3, p. 13-25, 2014.

* De acordo com:
ASSOCIAÇÃO BRASILEIRA DE NORMAS TÉCNICAS. NBR 6023: informação e documentação: referências: elaboração. Rio de Janeiro, 2002. 
BRADY, M. J.; NAIRN, A. C.; SALTIEL, A. R. The regulation of glycogen synthase by protein phosphatase 1 in 3T3-L1 adipocytes. Evidence for a potential role for DARPP-32 in insulin action. J. Biol. Chem., v. 272, n. 47, p. 29698-29703, 1997.

BRASIL. Ministério da Saúde. Secretaria de Vigilância em Saúde. Departamento de Análise da Situação de Saúde. Departamento de Informática do SUS. Indicadores de mortalidade. 2012. Disponível em: <http://tabnet.datasus.gov.br/cgi/deftohtm.exe?idb2012 /c12.def>. Acesso em: 25 jan. 2016.

. Indicadores de morbidade. 2013. Disponível em: <http://tabnet.datasus.gov.br/cgi/ deftohtm.exe?idb2012/d29.def>. Acessoem: 25 jan. 2016.

BROWNLEE, M.; AIELLO, L. P.; COOPER, M. E.; VINIK, A. I.; NESTO, R. W.; BOULTON, A. J. M. Complicações do diabete melito. In: KRONENBERG, H. M.; MELMED, S.; POLONSKY, K. S.; LARSEN P.R. Williams tratado de endocrinologia. 11. ed. Rio de Janeiro: Elsevier, 2010. p.1124-1189.

BUETTNER, R.; PARHOFER, K. G.; WOENCKHAUS, M.; WREDE, C.E.; KUNZ-SCHUGHART, L. A.; SCHOÖLMERICH, J.; BOLLHEIMER, L.C.; Defining high-fat-diet rat models: metabolic and molecular effects of different fat types. J. Mol. Endocrinol., v. 36, n. 3, p. 485-501, 2006.

BUSE, M. G. Hexosamines, insulin resistance, and the complications of diabetes: current status. Am. J. Physiol. Endocrinol. Metab., v. 290, n. 1, p. E1-E8, 2006.

CAl, L. Metallothionein as an adaptive protein prevents diabetes and its toxicity. Nonlinearity Biol. Toxicol.Med., v. 2, n. 2, p. 89-103, 2004.

CHALLISS, R. A.; LOZEMAN, F. J.; LEIGHTON, B.; NEWSHOLME, E. A. Effects of the betaadrenoceptor agonist isoprenaline on insulin-sensitivity in soleus muscle of the rat. Biochem. J., v. 233, n. 2, p. 377-381, 1986.

CHASAPIS, C. T.; LOUTSIDOU, A. C.; SPILIOPOULOU, C. A.; STEFANIDOU, M. E. Zinc and human health: an update. Arch. Toxicol., v. 86, n. 4, p. 521-534, 2012.

CHEN, M. D.; LIOU, S. J; LIN, P. Y.; YANG, V. C.; ALEXANDER, P. S.; LIN, W. H. Effects of zinc supplementation on the plasma glucose level and insulin activity in genetically obese (ob/ob) mice. Biol. Trace. Elem. Res., v. 61, n. 3, p. 303-311, 1998.

CHEN, M. D.; YANG, V. C.; ALEXANDER, P. S.; LIN, P. Y.; SONG, Y. M. Effects of selected minerals on leptin secretion in streptozotocin-induced hyperglycemic mice. Exp. Biol. Med. (Maywood), v. 226, n. 9, p. 836-840, 2001.

COLLINS, S. C.; HOPPA, M. B.; WALKER, J. N.; AMISTEN, S.; ABDULKADER, F.; BENGTSSON, M.; FEARNSIDE, J.; RAMRACHEYA, R.; TOYE, A. A.; ZHANG, Q.; CLARK, A.; GAUGUIER, D.; RORSMAN, P. Progression of diet-induced diabetes in C57BL6J mice involves functional dissociation of Ca2(+) channels from secretory vesicles. Diabetes, v. 59, n. 5, p. 1192-1201, 2010. 
COPPACK, S. W.; JENSEN, M. D.; MILES, J. M. In vivo regulation of lipolysis in humans. J. Lipid. Res., v. 35, n. 2, p. 177-193, 1994.

CORÉ, N.; CAUBIT, X.; METCHAT, A.; BONED, A.; DJABALI, M.; FASANO, L. Tshz1 is required for axial skeleton, soft palate and middle ear development in mice. Dev. Biol., $v$. 308, n. 2, p. 407-420, 2007.

COUDRAY, C.; RICHARD, M. J.; LAPORTE, F.; FAURE, P.; ROUSSEL, A. M.; FAVIER. A. Superoxide dismutase activity and zinc status: a study in animals and man. J. Nutr. Environ. Med.,v. 3, n. 1, p. 13-26, 1992.

COULSTON, L.; DANDONA, P. Insulin-like effects of zinc on adipocytes. Diabetes, v. 29, p. 665-667,1980.

COUSINS, R. Absorption, transport and hepatic metabolism of copper and zinc: special reference to metallothionein and ceruloplasmin. Physiol. Ver., v. 65, p. 238-308, 1985.

CRETTAZ, M.; PRENTKI, M.; ZANINETTI, D.; JEANRENAUD, B. Insulin resistance in soleus muscle from obese Zucker rats. Involvement of several defective sites. Biochem. J., v. 186, n. 2, p. 525-534, 1980.

CROSS, D. A.; ALESSI, D. R; COHEN, P.; ANDJELKOVICH, M.; HEMMINGS, B. A. Inhibition of glycogen synthase kinase-3 by insulin mediated by protein kinase B. Nature, v. 378, n. 6559, p. 785-789, 1995.

CUNNINGHAM, B. C.; BASS, S.; FUH, G.; WELLS, J. A. Zinc mediation of binding of human growth hormone to the human prolactin recptor. Science, v. 250, n. 4988 p. 1709-1712, 1990.

DANEMAN, D. Type 1 diabetes. Lancet, v. 367, n. 9513, p. 847-858, 2006.

DEFRONZO, R. A.; GUNNARSSON, R.; BJORKMAN, O.; OLSSON, M.; WAHREN, J. Effects of insulin on peripheral and splanchnic glucose metabolism in noninsulin-dependent (type II) diabetes mellitus. J. Clin. Invest., v.76, n. 1, p. 149-155, 1985.

DEVENDRA, D.; LIU, E.; EISENBARTH, G. S. Type 1 diabetes: recent developments. BMJ., v. 328, n. 7442, p. 750-754, 2004.

DODSON, G.; STEINER, D.The role of assembly in insulin's biosynthesis. Curr. Opin. Struct. Biol., v. 8, n. 2, p. 189-194, 1998.

DUFNER-BEATTIE, J.; KUO, Y. M.; GITSCHIER, J.; ANDREWS, G. K. The adaptive response to dietary zinc in mice involves the differential cellular localization and zinc regulation of the zinc transporters ZIP4 and ZIP5. J. Biol. Chem., v. 279, p. 49082-49090, 2004. 
DUFNER-BEATTIE, J.; WANG, F.; KUO, Y. M.; GITSCHIER, J.; EIDE, D.; ANDREWS, G. K. The acrodermatitis enteropathica gene ZIP4 encodes a tissue-specific, zinc-regulated zinc transporter in mice. J. Biol. Chem., v. 278, p. 33474-33481, 2003.

DUNN, M. F. Zinc-ligand interactions modulate assembly and stability of the insulin hexamer - a review. Biometals, v. 18, n. 4, p. 295-303, 2005.

DUPREZ, J.; ROMA, L. P.; CLOSE, A. F.; JONAS, J. C.; Protective antioxidant and antiapoptotic effects of $\mathrm{ZnCl}_{2}$ in rat pancreatic islets cultured in low and high glucose concentrations. Plos One, v. 7, n. 10, p. 1-11, 2012.

EMDIN, S. O.; DODSON, G. G.; CUTFIELD, J. M.; CUTFIELD, S. M. Role of zinc in insulin biosynthesis some possible zinc-Insulin interactions in the pancreatic $\beta$-cell. Diabetologia, $v$. 19, n. 3, p. 174-182, 1980.

FAURE, P.; ROUSSEL, A.; COUDRAY, C.; RICHARD, M. J.; HALIMI, S.; FAVIER, A. Zinc and insulin sensitivity. Biol. Trace. Elem. Res., v. 32, p.305-310, 1992.

FIGLEWICZ, D. P.; FORHAN, S. E.; HODGSON, A. T.; GRODSKY, G. M. Zinc and endogenous zinc content and distribution in islets in relationship to insulin content. Endocrinology, v. 115, n. 3, p. 877-881, 1984.

FOSTER, M. C.; LEAPMAN, R. D.; LI, M. X.; ATWATER, I. Elemental composition of secretory granules in pancreatic islets of Langerhans. Biophys. J., v. 64, n. 2, p. 525-532, 1993.

FRANKLIN, I.; GROMADA, J.; GJINOVCI, A.; THEANDER, S.; WOLLHEIM, C. B. B-cell secretory products activate $\alpha$-cell atp-dependent potassium channels to inhibit glucagon release. Diabetes, v. 54, n. 6, p. 1808-1815, 2005.

FREYSE, E. J.; FISCHER, U.; ALBRECHT, G.; MARX, S.; KEILACKER, H. The effect of prehepatic insulin administration on alanine flux rates in diabetic dogs. Diabetologia, v. 30, n. 6, p. 402408, 1987.

FUKADA, T.; YAMASAKI, S.; NISHIDA, K.; MURAKAMI, M.; HIRANO, T. Zinc homeostasis and signaling in health and diseases: Zinc signaling. J. Biol. Inorg. Chem., v. 16, n. 7, p. 11231134, 2011.

GALLAGHER, M. L. Os nutrientes e seu metabolismo. In: MANHAN L. K.; ESCOTT-STUMP S. Krause: alimentos, nutrição \& dietoterapia. 12.ed. São Paulo: Roca, 2010. p. 39-158.

GALLOU-KABANI, C.; VIGÉ, A.; GROSS, M.S.; RABÈS, J. P.; BOILEAU, C.; LARUE-ACHAGIOTIS, C.; TOMÉ, D.; JAIS, J. P.; JUNIEN, C. C57BL/6J and A/J mice fed a high-fat diet delineate components of metabolic syndrome. Obesity, v. 15, n. 8, p. 1996-2005, 2007.

GARG, V. K.; GUPTA, R.; GOYAL, R. K. Hypozincemia in diabetes mellitus. J. Assoc. Physicians India, v. 42, n. 9, p. 720-721, 1994. 
GARVEY, W. T.; MAIANU, L.; HUECKSTEADT, T. P.; BIRNBAUM, M. J.; MOLINA, J. M.; CIARALDI, T.P. Pretranslational suppression of a glucose transporter protein causes insulin resistance in adipocytes from patients with non-insulin-dependent diabetes mellitus and obesity. J. Clin. Invest., v. 87, n. 3, p. 1072-1081, 1991.

GONZALEZ, A.; MERINO, B.; MARROQUÍ, L.; ÑECO, P.; ALONSO-MAGDALENA, P.; CABALLEROGARRIDO, E.; VIEIRA, E.; SORIANO, S.; GOMIS, R.; NADAL, A.; QUESADA, I. Insulin hypersecretion in islets from diet-induced hyperinsulinemic obese female mice is associated with several functional adaptations in individual beta-cells. Endocrinology, v. 154, n. 10, p. 3515-3524, 2013.

GUARIGUATA, L.; WHITING, D. R.; HAMBLETON, I.; BEAGLEY, J.; LINNENKAMP, U.; SHAW, J. E. Global estimates of diabetes prevalence for 2013 and projections for 2035. Diabetes Res. Clin. Pract., v. 103, n. 2, p. 137-149, 2014.

GUPTA, R.; GARG, V. K.; MATHUR, D. K.; GOYAL, R. K. Oral zinc therapy in diabetic neuropathy. J. Assoc. Physicians India, v. 46, n. 11, p. 939-942, 1998.

HAASE, H.; MARET, W. Fluctuations of cellular, available zinc modulate insulin signaling via inhibition of protein tyrosine phosphatases. J. Trace Elem. Med. Biol., v. 19, n. 1, p. 37-42, 2005.

HALBAN, P. A.; POLONSKY, K. S.; BOWDEN, D. W.; HAWKINS, M. A.; LING, C.; MATHER, K. J.; POWERS, A. C.; RHODES, C. J.; SUSSEL, L.; WEIR, G. C. $\beta$-cell failure in type 2 diabetes: postulated mechanisms and prospects for prevention and treatment. J. Clin. Endocrinol. Metab., v. 99, n. 6, p. 1983-1992, 2014.

HEMPE, J. M.; COUSINS, R. J. Cysteine-rich intestinal protein and intestinal metallothionein: an inverse relationship as a conceptual model for zinc absorption in rats. J. Nutr., v. 122, n. 1, p. 89-95, 1992.

HENRY, C.; CLOSE, A. F.; BUTEAU, J. A Critical Role for the Neural Zinc Factor ST18 in Pancreatic $\beta$-Cell Apoptosis. J. Biol. Chem., v. 289, n. 12, p. 8413-8419, 2014.

HERBERG, L.; HERBERG, L.; DÖPPEN, W.; MAJOR, E.; GRIES, F. A. Dietary-induced hypertrophic hyperplastic obesity in mice. J. Lipid. Res., v. 15, n. 6, p. 580-585, 1974.

HUANG, L. Zinc and its transporters, pancreatic $\beta$-cells, and insulin metabolism. In: LITWACK, G. Vitamins and hormones. Burlington: Academic Press, 2014.v. 95, p. 365-390.

HUANG, L.; YAN, M.; KIRSCHKE, C. P. Over-expression of ZnT7 increases insulin synthesis and secretion in pancreatic $\beta$-cells by promoting insulin gene transcription. Exp. Cell Res., v. 316, n. 16, p. 2630-2643, 2010.

ILOUZ, R.; KAIDANOVICH, O.; GURWITZ, D.; ELDAR-FINKELMAN, H. Inhibition of glycogen synthase kinase-3beta by bivalent zinc ions: insight into the insulin-mimetic action of zinc. Biochem. Biophys. Res. Commun., v. 295, n. 1, p. 102-106, 2002. 
INTERNATIONAL DIABETES FEDERATION, IDF. Diabetes Atlas. [Internet] 7th ed. Brussels, 2015.p. 11-27, 50-65, 86-87. Disponívelem: < http://www.diabetesatlas.org/component/atta chments/?task=download\&id=116>. Acesso em: 13 jan. 2016.

JANSEN, J.; KARGES, W.; RINK, L. Zinc and diabetes-clinical links and molecular mechanisms. J. Nutr. Biochem., v. 20, n. 6, p. 399-417, 2009.

JANSEN, J.; ROSENKRANZ, E.; OVERBECK, S.; WARMUTH, S.; MOCCHEGIANI, E.; GIACCONI, R.; WEISKIRCHEN, R.; KARGES, W.; RINK, L. Disturbed zinc homeostasis in diabetic patients by in vitro and in vivo analysis of insulinomimetic activity of zinc. J. Nutr. Biochem., v. 23, n. 11, p. 1458-1466, 2012.

JAYAWARDENA, R.; RANASINGHE, P.; GALAPPATTHY, P.; MALKANTHI, R.; CONSTANTINE, G.; KATULANDA, P. Effects of zinc supplementation on diabetes melito: a systematic review and meta-analysis. Diabetol. Metab. Syndr., v. 4, n. 1, p. 4-13, 2012.

KAHN, B. B.; FLIER, J. S. Obesity and insulin resistance. J. Clin. Invest., v. 106, n. 4, p. 473-481, 2000.

KAMOHARA, S.; BURCELIN, R.; HALAAS, J. L.; FRIEDMAN, J. M.; CHARRON, M. J. Acute stimulation of glucose metabolism in mice by leptin treatment. Nature, v. 389, n. 6649, p. 374-377, 1997.

KARASAWA, H.; NAGATA-GOTO, S.; TAKAISHI, K.; KUMAGAE, Y. A novel model of type 2 diabetes mellitus based on obesity induced by high-fat diet in BDF1 mice. Metabolism, v. 58, n. 3, p. 296-303, 2009.

KEWALRAMANI, G.; BILAN, P. J.; KLIP, A. Muscle insulin resistance: assault by lipids, cytokines and local macrophages. Curr. Opin. Clin. Nutr. Metab. Care, v. 13, n. 4, p. 382-390, 2010.

KIM, Y. B.; NIKOULINA, S. E.; CIARALDI, T. P.; HENRY, R. R.; KAHN B. B. Normal insulindependent activation of Akt/protein kinase $B$, with diminished activation of phosphoinositide 3-kinase, in muscle in type 2 diabetes. J. Clin. Invest., v. 104, n.6, p.733741, 1999.

KIM, Y.; IWASHITA, S.; TAMURA, T.; TOKUYAMA, K.; SUZUKI, M. Effect of high-fat diet on the gene expression of pancreatic GLUT2 and glucokinase in rats. Biochem. Biophys. Res. Commun., v. 208, n.3, p. 1092-1098, 1995.

KING, J. C.; SHAMES, D. M.; WOODHOUSE, L. R. Zinc homeostasis in humans. J. Nutr., v. 130, p. 1360-1366, 2000.

KINLAW, W. B.; LEVINE, A. S.; MORLEY, J. E.; SILVIS, S. E.; MCCLAIN, C. J. Abnormal zinc metabolism in type II diabetes mellitus. Am. J. Med., v. 75, n. 2, p. 273-277, 1983.

KOPELMAN, P. G. Obesity as a medical problem. Nature, v. 6, n. 404, p. 635-643, 2000. 
KRISHNA, S. S.; MAJUMDAR, I.; GRISHIN, N. V. Structural classification of zinc fingers: survey and summary. Nucleic. Acids. Res., v. 31, n. 2; p. 532-550, 2003.

KRUSE-JARRES, J. D.; RÜKGAUER, M. Trace elements in diabetes mellitus. Peculiarities and clinical validity of determinations in blood cells. J. Trace. Elem. Med. Biol., v. 14, n. 1, p. $21-$ 77, 2000.

LAITY, J. H.; LEE, B. M.; WRIGHT, P. E. Zinc finger proteins: new insights into structural and functional diversity. Curr. Opin. Struct. Biol., v. 11, n. 1, p. 39-46, 2001.

LAVAU, M.; FRIED, S. K.; SUSINI, C.; FREYCHET, P. Mechanism of insulin resistance in adipocytes of rats fed a high-fat diet. J. Lipid. Res. v. 20, n. 1, p. 8-16, 1979.

LAYCHOCK, S. G.; DUZEN, J.; SIMPKINS, C. O. Metallothionein induction in islets of Langerhans and insulinoma cells. Mol. Cell. Endocrinol., v. 165, n. 2, p. 179-187, 2000.

LEE, D.K.; GEISER, J.; DUFNER-BEATTIE, J.; ANDREWS, G.K. Pancreatic metallothionein-I may play a role in zinc homeostasis during maternal dietary zinc deficiency in mice. J. Nutr., v. 133, n. 1, p. 45-50, 2003.

LEWIS, R. J. Sax's dangerous properties of industrial materials. 9. ed. Hoboken: WileyInterscience, Wiley \& Sons, 1996.

LICHTI-KAISER, K.; ZERUTH, G.; KANG, H. S.; VASANTH, S.; JETTEN, A. M. Gli-similar proteins: their mechanisms of action, physiological functions, and roles in disease. Vitam. Horm., v. 88, p. 141-171, 2012.

LIU, L.; KARKANIAS, G. B.; MORALES, J. C.; HAWKINS, M.; BARZILAI, N.; WANG, J.; ROSSETTI, L. Intracerebroventricular leptin regulates hepatic but not peripheral glucose fluxes. J. Biol. Chem., v. 273, n. 47, p. 31160-31167, 1998.

LIU, Z.; PATIL, I. Y; JIANG, T.; SANCHETI, H.; WALSH, J. P.; STILES, B. L.; YIN, F.; CADENAS, E. High-fat diet induces hepatic insulin resistance and impairment of synaptic plasticity. PLoS One, v. 10, n. 5, p. 1-16, 2015.

LIUZZI, J. P.; BOBO, J. A.; CUI, L.; MCMAHON, R. J.; COUSINS, R. J. Zinc transporters 1, 2 and 4 are differentially expressed and localized in rats during pregnancy and lactation. J. Nutr., v. 133, p. 342-351, 2003.

LOWE, N. M.; FEKETE, K.; DECSI, T. Methods of assessment of zinc status in humans: a systematic review. Am. J. Clin. Nutr.,v. 89, n.6, p. 2040S-2051S, 2009.

MAIO, J. M.; CONTOREGGI, C. S.The mechanism of the insulin-like effects of ionic zinc. J. Biol. Chem., v. 257, n. 8, p. 4362-4368, 1982.

MIAO, X.; SUN, W.; FU, Y.; MIAO, L.; CAI, L. Zinc homeostasis in the metabolic syndrome and diabetes. Front. Med., v. 7, n. 1, p. 31-52, 2013. 
MALTA, D. C.; MOURA, L.; PRADO, R. R.; ESCALANTE, J. C.; SCHMIDT, M. I.; DUNCAN, B. B. Mortalidade por doenças crônicas não transmissíveis no Brasil e suas regiões, 2000 a 2011. Epidemiol. Serv. Saúde, v. 23, n. 4, p. 599-608, 2014.

MANTZOROS, C. S.; PRASAD, A. S.; BECK, F. W.; GRABOWSKI, S.; KAPLAN, J.; ADAIR, C.; BREWER, G. J. Zinc may regulate serum leptin concentrations in humans. J. Am. Coll. Nutr., v. 17, n. 3, p. 270-275, 1998.

MARET, W. Analyzing free zinc (ii) ion concentrations in cell biology with fluorescent chelating molecules. Metallomics, v.7, n. 2, p. 202-211, 2015.

. Metallothionein redox biology in the cytoprotective and cytotoxic functions of zinc.

Exp. Gerontol., v. 43, n.5, p. 363-369, 2008.

MARTINS, A. R.; NACHBAR, R. T.; GORJAO, R.; VINOLO M. A.; FESTUCCIA W. T.; LAMBERTUCCI R. H.; CURY-BOAVENTURA M. F.; SILVEIRA L. R.; CURI R.; HIRABARA S. M. Mechanisms underlying skeletal muscle insulin resistance induced by fatty acids: importance of the mitochondrial function. Lipids Health Dis., n. 11, v. 30, 2012.

MATTHEWS, D. R.; HOSKER, J. P.; RUDENSKI, A. S.; NAYLOR, B. A.; TREACHER, D. F.; TURNER, R. C. Homeostasis model assessment: insulin resistance and beta-cell function from fasting plasma glucose and insulin concentrations in man. Diabetologia, v. 28, n. 7, p. 412-419, 1985.

MCMAHON, R. J.; COUSINS, R. J. Regulation of the zinc transporter ZnT-1 by dietary zinc. Proc. Natl. Acad. Sci., v.95, p 4841-4846, 1998.

MORGAN, C.R.; LAZAROW, A. Immunoassay of insulin: two antibody system plasma insulin levels of normal, subdiabetic and diabetic rats. Diabetes, v. 12, n. 2, p. 115-126, 1963.

MÜNZBERG, H.; FLIER J. S.; BJØRBAEK C. Region-Specific Leptin Resistance within the Hypothalamus of Diet-Induced Obese Mice. Endocrinology, v.145, n.11, p. 4880-4889, 2004.

NAITO, Y.; YOSHIKAWA, Y.; YASUI, H. Cellular mechanism of zinchinokitiol complexes in diabetes mellitus. Bull. Chem. Soc. Jpn., v. 84, n. 3, p. 298-305, 2011.

NAKAYAMA, A.; HIROMURA, M.; ADACHI, Y.; SAKURAI, H. Molecular mechanism of antidiabetic zinc-allixin complexes: regulations of glucose utilization and lipid metabolism. J. Biol. Inorg. Chem., v. 13, n. 5, p. 675-684, 2008.

NYGAARD, S. B.; LARSEN, A.; KNUHTSEN, A.; RUNGBY, J.; SMIDT, K. Effects of zinc supplementation and zinc chelation on in vitro $\beta$-cell function in INS-1E cells. BMC. Res. Notes., v. 7, p.77-84, 2004.

OKAMOTO, T.; KUROKI, T.; ADACHI, T.; ONO, S.; HAYASHI, T.; TAJIMA, Y.; EGUCHI, S.; KANEMATSU, T.Effect of zinc on early graft failure following intraportal islet transplantation in rat recipients. Ann. Transplant., v. 16, n. 3, p. 114-120, 2011. 
PASCOE, L.; FRAYLING, T. M.; WEEDON, M. N.; MARI, A.; TURA, A.; FERRANNINI, E.; WALKER, M.; RISC, C. Beta cell glucose sensitivity is decreased by $39 \%$ in non-diabetic individuals carrying multiple diabetes-risk alleles compared with those with no risk alleles. Diabetologia, v. 51, n. 11, p. 1989-1992, 2008.

PILKIS, S. J.; FOX, E.; WOLFE, L.; ROTHBARTH, L.; COLOSIA, A.; STEWART, H. B.; ELMAGHRABI M.R. Hormonal modulation of key hepatic regulatory enzymes in the gluconeogenic/glycolytic pathway. Ann. N. Y. Acad. Sci., v. 478, p. 1-19, 1986.

PLUM, L. M.; RINK, L.; HAASE, H. The essential toxin: impact of zinc on human health. Int. J. Environ. Res. Public. Health, v. 7, n. 4, p. 1342-1365, 2010.

POLOZ, Y.; STAMBOLIC, V. Obesity and cancer, a case for insulin signaling. Cell. Death. Dis., v. 6, n. 12, 2015.

PRASAD, A. S. Clinical manifestations of zinc deficiency. Annu. Rev. Nutr., v. 5, p. 341-63, 1985.

PRASAD, A. S.; BAO, B.; BECK, F. W.; KUCUK, O.; SARKAR, F. H. Antioxidant effect of zinc in humans. Free Radic. Biol. Med., v. 37, n. 8, p. 1182-1190, 2004.

QUARTERMAN, J.; MILLS, C.; HUMPHRIES, W. The reduced of and sensitivity to insulin in Zndeficient rats. BBRC, v. 25, n. 3, p. 354-358, 1966.

RAUM, J. C.; SOlEIMANPOUR, S. A.; GROFF, D. N.; CORÉ, N.; FASANO, L.; GARRATT, A. N.; DAI, C. POWERS, A. C.; STOFFERS, D. A. Tshz1 regulates pancreatic beta cell maturation. Diabetes, v. 64, n. 6, p. 2905-2914, 2015.

REEVES, P. G.; NIELSEN, F. H.; FAHEY, G. C. AIN-93 purified diets for laboratory rodents: final report of the American Institute of Nutrition ad hoc writing committee on the reformulation of the AIN-76A rodent diet. J. Nutr., v. 123, n. 11, p. 1939-1951, 1993.

REIMER, M. K.; AHREN, B. Altered $\beta$-cell distribution of pdx-1 and GLUT-2 after a short-term challenge with a high-fat diet in C57BL/6J mice. Diabetes, v. 51, n. 1, p. S138-S143, 2002.

RICHARDSON, J. M.; BALON, T. W.; TREADWAY, J. L.; PESSIN, J. E. Differential regulation of glucose transporter activity and expression in red and white skeletal muscle. J. Biol. Chem., v. 266, n. 19, p. 12690-12694, 1991.

RIVERO-GUTIÉRREZ, B.; ANZOLA, A.; MARTínEZ-AUGUSTIN, O.; DE MEDINA, F. S. Stain-free detection as loading control alternative to Ponceau and housekeeping protein immunodetection in Western blotting. Anal Biochem., v. 15, n. 467, p. 1-3, 2014.

ROMERO-CALVO, I.; OCÓN, B.; MARTÍNEZ-MOYA, P.; SUÁREZ, M. D.; ZARZUELO, A.; MARTÍNEZ-AUGUSTIN, O.; DE MEDINA, F. S. Reversible Ponceau staining as a loading control alternative to actin in Western blots. Anal Biochem., v. 15, n. 401, p. 318-320, 2010. 
RONDINONE,C. M.; WANG, L.; LONNROTH, P.;WESSLAU, C.; PIERCE, J. H.; SMITH, U. Insulin receptor substrate (IRS) 1 is reduced and IRS-2 is the main docking protein for phosphatidylinositol 3-kinase in adipocytes from subjects with non-insulin-dependent diabetes melito. Proc. Natl. Acad. Sci. USA, v.94, n. 8, p.4171-4175, 1997.

ROSSETTI, L.; MASSILLON, D.; BARZILAI, N.; VUGUIN, P.; CHEN, W.; HAWKINS, M.; WU, J.; WANG, J. Short term effects of leptin on hepatic gluconeogenesis and in vivo insulin action. J. Biol. Chem., v. 272, n. 44, p. 27758-27763, 1997.

ROUSSEL, A.; KERKENI, A.; ZOUARI, N.; MAJOUB, S.; MATHEAU, J.; ANDERSON, R. A. Antioxidant Effects of zinc supplementation in Tunisians with type 2 diabetes mellitus. J. Am. Coll. Nutr., v. 22, n. 4, p. 316-321, 2003.

SALGUEIRO, M. J.; ZUBILLAGA, M.; LYSIONEK, A.; SARABIA, M. I.; CARO, R.; DE PAOLI, T.; HAGER, A.; WEILL, R.; BOCCIO, J. Zinc as an essential micronutrient: a review. Nutr. Res., p. 20, n. 5, p. 737-755, 2000.

SANDSTRÖM, B. Bioavailability of zinc. Eur. J. Clin. Nut., v. 51, p. 17-19, 1997.

SAPER, R. B.; RASH, R. Zinc: an essential micronutrient. Am. Fam. Physician., v.79, n. 9, p. 768-772, 2009.

SCHMIDT, M. I.; DUNCAN, B. B.; AZEVEDO E SILVA, G.; MENEZES, A. M.; MONTEIRO, C. A.; BARRETO, S.M.; CHOR, D.; MENEZES, P.R. Chronic non-communicable diseases in Brazil: burden and current challenges. Lancet, v. 4, n. 377, p. 1949-1961, 2011.

SCOTT, D. A. Crystalline insulin. Biochem. J., v. 28, n. 4, p. 1592-1602, 1934.

SCOTT, D. A.; FISHER A. M. The insulin and the zinc content of normal and diabetic pancreas. J. Clin. Invest., v. 17, n. 6, p. 725-728, 1938.

SCOTTO, M.; AFONSO, G.; LARGER, E.; RAVERDY, C.; LEMONNIER, F. A.; CAREL, J. C.; DUBOISLAFORGUE, D.; BAZ, B.; LEVY, D.; GAUTIER, J. F.; LAUNAY, O.; BRUNO, G.; BOITARD, C.; SECHI, L. A.; HUTTON, J. C.; DAVIDSON, H. W.; MALLONE, R. Zinc transporter (ZnT)8 (186-194) is an immunodominant CD8+ T cell epitope in HLA-A2+ type 1 diabetic patients. Diabetologia, $v$. 55, n. 7, p. 2026-2031, 2012.

SENSI, S. L.; PAOLETTI, P.; BUSH, A. I.; SEKLER, I. Zinc in the physiology and pathology of the CNS. Nat. Rev. Neurosci., v. 10, n. 11, p. 780-791, 2009.

SILVA, M. R.; SILVA, M. A. A. P. Aspectos nutricionais de fitatos e taninos. Ver. Nutr., v. 12, n. 1, p. 21-32, 1999.

SIMON, S. F.; TAYLOR, C. G. Dietary zinc supplementation attenuates hyperglycemia in $\mathrm{db} / \mathrm{db}$ mice. Exp. Med. Biol., v. 226, n. 1, p. 43-51, 2001. 
SLEPCHENKO, K. G.; LI, Y. V. Rising intracellular zinc by membrane depolarization and glucose in insulin-secreting clonal HIT-T15 beta cells. Exp. Diabetes Res., p. 190309, 2012.

SOINIO, M.; MARNIEMI, J.; LAAKSO, M.; PYÖRÄLÄ, K.; LEHTO, S.; RÖNNEMAA, T. Serum zinc level and coronary heart disease events in patients with type 2 diabetes. Diabetes Care, $v$. 30, n. 3, p. 523-528, 2007.

SONDERGAARD, L. G.; STOLTENBERG, M.; FLYVBJERG, A.; BROCK, B.; SCHMITZ, O.; DANSCHER, G.; RUNGBY, J. Zinc ions in beta-cells of obese, insulin-resistant, and type 2 diabetic rats traced by autometallography. APMIS, v. 111, n. 12, p. 1147-1154, 2003.

SONE, H.; KAGAWA, Y. Pancreatic $\beta$ cell senescence contributes to the pathogenesis of type 2 diabetes in high-fat diet-induced diabetic mice. Diabetologia, v. 48, p. 1, p. 58-67, 2004.

STEFANIDOU, M.; MARAVELIAS, C.; DONA, A.; SPILIOPOULOU, C. Zinc: a multipurpose trace element. Arch. Toxicol., v. 80, n. 1, p. 1-9, 2006.

STEVENSON, R. W.; WILLIAMS, P. E.; CHERRINGTON, A. D. Role of glucagon suppression on gluconeogenesis during insulin treatment of the conscious diabetic dog. Diabetologia, v. 30, p. 782-790, 1987.

TAMAKI, M.; FUJITANI, Y.; UCHIDA, T.; HIROSE, T.; KAWAMORI, R.; WATADA, H. Downregulation of ZnT8 expression in pancreatic $\beta$-cells of diabetic mice. Islets, v. $1, \mathrm{n} .2$, p. 124-128, 2009.

TANG, X.; SHAY, N. F. Zinc has an insulin-like effect on glucose transport mediated by phosphoinositol-3-kinase and Akt in 3T3-L1 fibroblasts and adipocytes. J. Nutr., v. 131, n. 5, p. 1414-1420, 2001.

TAPIERO, H.; TEW, K. D. Trace elements in human physiology and pathology: zinc and metallothioneins. Biomed. Pharmacother., v. 57, n. 9, p. 399-411, 2003.

TAYLOR, C. G. Zinc, the pancreas, and diabetes: insights from rodent studies and future directions. Biometals, v. 18, n. 4, p. 305- 312, 2005.

THIEBAUD, D.; JACOT, E.; DEFRONZO, R. A.; MAEDER, E.; JEQUIER, E.; FELBER, J. P. The effect of graded doses of insulin on total glucose uptake, glucose oxidation, and glucose storage in man. Diabetes, v. 31 n. 11, p. 957-963, 1982.

VASAK, M. Metallothioneins: chemical and biological challenges. J. Biol. Inorg. Chem., v. 16, n. 7, p. 975-976, 2011.

VERAS, K.; ALMEIDA, F. N.; NACHBAR, R. T.; DE JESUS, D. S.; CAMPOREZ, J. P.; CARPINELLI, A. R.; GOEDECKE, J. H.; DE OLIVEIRA-CARVALHO, C. R. DHEA supplementation in ovariectomized rats reduces impaired glucose-stimulated insulin secretion induced by a high-fat diet. FEBS Open Bio., v. 18, n. 4, p. 141-146, 2014. 
VIKTORÍNOVÁ, A.; TOSEROVÁ, E.; KRIZKO, M.; DURACKOVÁ, Z. Altered metabolism of copper, zinc, and magnesium is associated with increased levels of glycated hemoglobin in patients with diabetes mellitus. Metabolism., v. 58, n. 10, p. 1477-1482, 2009.

WATSON, R. T.; PESSIN, J. E. Glut translocation: the last 200 nanometers. Cell Signal, v. 19, n. 11, p. 2209-2217, 2007.

WEST, D. B.; YORK, B. Dietary fat, genetic predisposition, and obesity: lessons from animal models. Am. J. Clin. Nutr., v. 67, n, 3. p. 505-512, 1998.

XU, J.; WANG, J.; CHEN, B. SLC30A8 (ZnT8) variations and type 2 diabetes in the Chinese Han population. Genet. Mol. Res., v. 11, n. 2, p. 1592-1598, 2012.

YAMASAKI, S.; SAKATA-SOGAWA, K.; HASEGAWA, A.; SUZUKI, T.; KABU, K.; SATO, E.; KUROSAKI, T.; YAMASHITA, S.; TOKUNAGA, M.; NISHIDA, K.; HIRANO, T. Zinc is a novel intracellular second messenger. J. Cell. Biol., v. 177, n. 4, p. 637-645, 2007.

YANG, J.; CHERIAN, M. G. Protective effects of metallothionein on streptozotocin-induced diabetes in rats. Life Sci., v. 55, n. 1, p. 43-51, 1994.

YANG, Y.; CHANG, B. H.; SAMSON, S. L.; LI, M. V.; CHAN, L. The Krüppel-like zinc finger protein Glis3 directly and indirectly activates insulin gene transcription. Nucleic. Acids. Res., v. 37, n. 8, p. 2529-2538, 2009.

YOSHIKAWA, Y.; UEDA, E.; KOJIMA, Y.; SAKURAI, H.The action mechanism of zinc(II) complexes with insulinomimetic activity in rat adipocytes. Life Sci., v. 75, n. 6, p. 741-751, 2004.

YU, Y. Y.; KIRSCHKE, C. P.; HUANG, L. Immunohistochemical analysis of ZnT1, 4, 5, 6, and 7 in the mouse gastrointestinal tract. J. Histochem. Cytochem., v. 55, p. 223-234, 2007.

ZHANG,Y. Y.; PROENCA, R.; MAFFEI, M.; BARONE, M.; LEOPOLD, L.; FRIEDMAN, J. M. Positional of the mouse obese gene and its human homolog. Nature, v. 372, n. 6505, p. 425432, 1994. 